\title{
COMPORTAMENTO DE REATOR ANAERÓBIO OPERADO EM BATELADA SEQÜENCIAL, CONTENDO BIOMASSA IMOBILIZADA E SUBMETIDO A AUMENTO PROGRESSIVO DA CONCENTRAÇÃO DE SUBSTRATO DE FÁCIL DEGRADAÇÃO
}

Ana Paula Miqueleto

Dissertação apresentada à Escola de Engenharia de São Carlos da Universidade de São Paulo, como parte dos requisitos para obtenção do título de Mestre em Engenharia Civil - Hidráulica e Saneamento

ORIENTADOR: Prof. Dr. Marcelo Zaiat

SÃO CARLOS

2003 
Aos meus pais, J cãoe Ceáliae masimãos, Kleber eRonaldo por tudo quesau hige 


\section{AGRADECIMENTOS}

A Marcelo Zaiat, pela amizade, orientação, incentivo, dedicação, compreensão e principalmente por ser um exemplo de honestidade e competência;

À Eloísa Pozzi Gianotti, pela amizade e colaboração nas análises microbiológicas;

À Beth Moraes e Janja, pela amizade e auxílio no LBP;

A Ricardo Monteiro pelo incentivo e ajuda na etapa final deste trabalho e por compartilhar momentos que se tornaram especiais por sua presença.

Às minhas irmãs Elis e Nélida que me deram dois sobrinhos maravilhosos, Gabriela e Guilherme, e por tudo que aprendi com vocês.

Às eternas amigas Laurice e Leonice, que de maneira direta ou indireta também contribuíram para o meu crescimento;

Aos grandes amigos Saulo, Katt, Luis Hamilton, Selma, Edson e Guilherme;

À Bianca, aos "Sérgios" cearenses, Alisson e todos outros que eu tive o prazer de conhecer e conviver durante este tempo;

A Tati, Di, Edson "Anderson" e Karina (Rep. Naja Maika) pela amizade que cultivamos durante os anos de convivência.

Aos amigos do laboratório: Dirlane, Edson, Betão, Sávia, Flavinha, Isabel, Valquiria, Luis Ricardo, Eduardo, Mércia, Arnaldo, Ari, Rogers, Samantha, Andréa, Renata, ...pelos momentos de descontração, os cafezinhos em que eu só acompanhei e ajudas quando o reator resolvia dar algum problema; 
À Flavia e Fernanda da contabilidade pela ajuda na contabilização das prestações de contas para a FAPESP;

Aos professores e funcionários do SHS/EESC, enfim, a todos que de alguma forma contribuíram para o desenvolvimento deste trabalho;

À FAPESP pelo auxílio financeiro ao projeto e pela bolsa de estudos concedida. 


\section{SUMÁRIO}

LISTA DE FIGURAS

LISTA DE TABELAS $\quad$ ix

LISTA DE ABREVIATURAS Xi

LISTA DE SIMBOLOS Xii

RESUMO xiii

ABSTRACT xiv

1. INTRODUÇÃO 1

2. OBJETIVO 3

3. REVISÃO BIBLIOGRÁFICA 4

3.1. Reator Anaeróbio em Batelada Seqüencial (ASBR) 4

3.2. Estudos Realizados com o ASBR Utilizando Glicose ou Sacarose como

Substrato

3.3. Biomassa Imobilizada em Espuma de Poliuretano 9

3.4. Estudos em Reatores Anaeróbios em Batelada Seqüencial Contendo Células 11

Imobilizadas (ASBBR)

3.5. Estudos Cinéticos em Reatores em Batelada Seqüencial com Células 12

Imobilizadas (ASBBR)

3.6. Exopolissacarídeo (EPS) ou Polímero Extracelular 14

4. MATERIAL E MÉTODOS 18

$\begin{array}{ll}\text { 4.1. Material } & 18\end{array}$

$\begin{array}{ll}\text { 4.1.1. Configuração do reator em batelada } & 18\end{array}$

4.1.2. Suporte de Imobilização da Biomassa Anaeróbia 19

4.1.3. Inóculo 19

4.1.4. Água Residuária Sintética 19

4.2. Métodos 20

4.2.1. Determinação da Concentração de Glicose 20

4.2.2. Ácidos Voláteis Totais por Cromatografia Gasosa 21

4.2.3. Análise DQO, Sólidos, Ácidos Voláteis Totais e Alcalinidade a 21

Bicarbonato

4.2.4. Exames Microbiológicos 22

4.2.5. Coloração Gram 22

4.2.6. Composição dos Gases 23

$\begin{array}{ll}\text { 4.2.7. Potencial Redox } & 23\end{array}$ 
5.1. Operação do ASBR com 8 horas de ciclo - $1^{\text {a }}$ Etapa 24

5.1.1. Imobilização da Biomassa Anaeróbia $\quad 24$

5.1.2. Amostragem 25

5.1.3. Operação do ASBBR com Aumento Progressivo da Concentração de 25

Glicose no Afluente

5.2. Operação do ASBR com 3 horas de Ciclo - 2 $2^{\mathrm{a}}$ Etapa 27

5.3. Resumo das Condições Experimentais 27

6. RESULTADOS E DISCUSSÕES 29

6.1.Operação do ASBBR com 8 horas de Ciclo - $1^{\text {a }}$ Etapa 29

6.1.1. Operação com Aproximadamente $500 \mathrm{mg} / \mathrm{L}$ de Glicose 29

6.1.2. Operação com Aproximadamente $1000 \mathrm{mg} / \mathrm{L}$ de Glicose 39

6.1.3. Operação com Aproximadamente $2000 \mathrm{mg} / \mathrm{L}$ de Glicose 48

6.2. Operação do ASBBR com 3 horas de Ciclo - 2a Etapa 54

6.2.1. Operação com Aproximadamente 500mg/L de Glicose 54

6.2.2. Operação com Aproximadamente $1000 \mathrm{mg} / \mathrm{L}$ de Glicose 61

6.3. Estudos Cinéticos 65

6.4. Exames Microbiológicos $\quad 71$

7. CONCLUSÕES

8. SUGESTÕES

9. REFERÊNCIAS 


\section{LISTA DE FIGURAS}

Figura 3.1: Etapas de operação do reator em batelada (DAGUE et al., 1992).

Figura 4.1: Esquema do Reator Anaeróbio Seqüencial em Batelada.

Figura 6.1: Valores de concentração de glicose afluente (-) e de DQO filtrada do afluente $(\bullet)$ e efluente $(\stackrel{\bullet}{)}$ durante o período de operação do ASBBR alimentado com $470 \pm 37 \mathrm{mg} / \mathrm{L}$ de glicose e 8 horas de ciclo.

Figura 6.2: Eficiência de redução de DQO filtrada (•) durante o período de operação do ASBBR alimentado com $470 \pm 37 \mathrm{mg} / \mathrm{L}$ de glicose e 8 horas de ciclo.

Figura 6.3: Valores da concentração de ácidos voláteis totais, obtidos por 32 cromatografia, do afluente $(\bullet)$ e do efluente $(\bullet)$ durante o período de operação do ASBBR alimentado com $470 \pm 37 \mathrm{mg} / \mathrm{L}$ de glicose e 8 horas de ciclo.

Figura 6.4: Valores das concentrações dos ácidos propiônico (•), butírico (^) e 32 isobutírico $(\bullet)$ no afluente, obtidos durante o período de operação do ASBBR alimentado com $470 \pm 37 \mathrm{mg} / \mathrm{L}$ de glicose e 8 horas de ciclo.

Figura 6.5: Valores das concentrações dos ácidos propiônico (๘), butírico ( ${ }^{\star}$ ), isovalérico $(\bullet)$ e isobutírico $(\bullet)$ no efluente, obtidos durante o período de operação do ASBBR alimentado com $470 \pm 37 \mathrm{mg} / \mathrm{L}$ de glicose e 8 horas de ciclo.

Figura 6.6: Valores da concentração de ácidos totais, obtidos por titulometria, do afluente $(\bullet)$ e do efluente $(\bullet)$ durante o período de operação do ASBBR alimentado com $470 \pm 37 \mathrm{mg} / \mathrm{L}$ de glicose e 8 horas de ciclo. 
Figura 6.7:Alcalinidade a bicarbonato do afluente $(\bullet)$ e do efluente $(\bullet)$ durante o 34 período de operação do ASBBR alimentado com $470 \pm 37 \mathrm{mg} / \mathrm{L}$ de glicose e 8 horas de ciclo.

Figura 6.8: Relação da composição molar entre os gases $\mathrm{CH} 4$ e $\mathrm{CO} 2$ durante o 34 período de operação do ASBBR alimentado com $470 \pm 37 \mathrm{mg} / \mathrm{L}$ de glicose e 8 horas de ciclo.

Figura 6.9:Perfil de DQO (•), concentração de glicose (•), AVT pelo método 36 cromatografico $(\nabla)$, alcalinidade a bicarbonato $(\diamond)$ e potencial redox $\left({ }^{\star}\right)$ do ASBBR alimentado com $470 \pm 37 \mathrm{mg} / \mathrm{L}$ de glicose e 8 horas de ciclo.

Figura 6.10: Concentrações de AVT, determinado por cromatografia, durante o perfil 36 temporal do ASBBR alimentado com $470 \pm 37 \mathrm{mg} / \mathrm{L}$ de glicose e 8 horas de ciclo.

Figura 6.11: Concentrações dos ácidos acético (๘), propiônico $(\bullet)$ e butírico durante 37 o perfil temporal do ASBBR alimentado com $470 \pm 37 \mathrm{mg} / \mathrm{L}$ de glicose e 8 horas de ciclo.

Figura 6.12: Valores da alcalinidade a bicarbonato determinado durante o perfil 37 temporal do ASBBR alimentado com $470 \pm 37 \mathrm{mg} / \mathrm{L}$ de glicose e 8 horas de ciclo.

Figura 6.13: Perfil da composição de gases, representado como a relação de $\mathrm{CH} 4$ e 38 CO2, no ASBBR alimentado com $470 \pm 37 \mathrm{mg} / \mathrm{L}$ de glicose e 8 horas de ciclo.

Figura 6.14: Valores de concentração de glicose afluente e DQO filtrada do afluente 40

$(\bullet)$ e efluente $\left({ }^{-}\right)$durante o período de operação do ASBBR alimentado com $852 \pm$ $190 \mathrm{mg} / \mathrm{L}$ de glicose e 8 horas de ciclo.

Figura 6.15: Eficiência de redução da DQO (ロ) durante o período de operação do 40 ASBBR alimentado com $852 \pm 190 \mathrm{mg} / \mathrm{L}$ de glicose e 8 horas de ciclo.

Figura 6.16: Análise da produção de ácidos voláteis totais, obtidos por 
cromatografia, do afluente $(\bullet)$ e do efluente $(\bullet)$ durante o período de operação do ASBBR alimentado com $852 \pm 190 \mathrm{mg} / \mathrm{L}$ de glicose e 8 horas de ciclo.

Figura 6.17: Valores das concentrações dos ácidos acético (•), propiônico (•) e butírico $\left(^{\wedge}\right.$ ) obtidos por cromatografia, do afluente durante o período de operação do ASBBR alimentado com $852 \pm 190 \mathrm{mg} / \mathrm{L}$ de glicose e 8 horas de ciclo

Figura 6.18: Valores da concentração dos ácidos acético (•), propiônico (•) e butírico $\left({ }^{\star}\right)$ obtidos por cromatografia, do efluente durante o período de operação do ASBBR alimentado com $852 \pm 190 \mathrm{mg} / \mathrm{L}$ de glicose e 8 horas de ciclo.

Figura 6.19: Alcalinidade a bicarbonato do afluente $(\bullet)$ e efluente $(\bullet)$ durante o período de operação do ASBBR alimentado com $852 \pm 190 \mathrm{mg} / \mathrm{L}$ de glicose e 8 horas de ciclo

Figura 6.20: Relação entre a composição molar dos gases $\mathrm{CH}_{4}$ e $\mathrm{CO}_{2}$ durante o período de operação do ASBBR alimentado com $852 \pm 190 \mathrm{mg} / \mathrm{L}$ de glicose e 8 horas de ciclo.

Figura 6.21: Perfil de DQO (๘), glicose $(\bullet)$, alcalinidade a bicarbonato $(\diamond), \operatorname{AVT}_{c}(\tau)$ 45 e potencial redox $\left({ }^{\wedge}\right)$ do ASBBR alimentado com $852 \pm 190 \mathrm{mg} / \mathrm{L}$ de glicose e 8 horas de ciclo.

Figura 6.22: Concentrações dos AVT, determinado por cromatografia, durante o 45 perfil temporal do ASBBR alimentado com $852 \pm 190 \mathrm{mg} / \mathrm{L}$ de glicose e 8 horas de ciclo.

Figura 6.23: Concentrações dos ácidos acético $(\bullet)$, propiônico $(\bullet)$ e butírico $\left({ }^{\bullet}\right)$ 46 durante o perfil temporal do ASBBR alimentado com $852 \pm 190 \mathrm{mg} / \mathrm{L}$ de glicose e 8 horas de ciclo.

Figura 6.24: Valores da alcalinidade a bicarbonato determinado durante o perfil 
temporal do ASBBR alimentado com $852 \pm 190 \mathrm{mg} / \mathrm{L}$ de glicose e 8 horas de ciclo.

Figura 6.25: Perfil da composição de gases, representado como a relação de $\mathrm{CH}_{4} \mathrm{e}$ $\mathrm{CO}_{2}$, no ASBBR alimentado com $852 \pm 190 \mathrm{mg} / \mathrm{L}$ de glicose e 8 horas de ciclo.

Figura 6.26: Valores da concentração glicose afluente (-) e DQO filtrada do afluente $(\bullet)$ e efluente $\left(\wedge^{\bullet}\right)$ e DQO bruta do efluente $\left({ }^{\bullet}\right)$ durante o período de operação do ASBBR alimentado com $1943 \pm 205 \mathrm{mg} / \mathrm{L}$ de glicose e 8 horas de ciclo.

Figura 6.27: Eficiência de redução da DQO bruta $(\bullet)$ e filtrada (•) durante o período de operação do ASBBR alimentado com $1943 \pm 205$ mg/L de glicose e 8 horas de ciclo.

Figura 6.28: Análise da produção de ácidos voláteis totais, obtidos por cromatografia, do afluente $(\bullet)$ e efluente $(\bullet)$ durante o período de operação do ASBBR alimentado com $1943 \pm 205 \mathrm{mg} / \mathrm{L}$ de glicose e 8 horas de ciclo.

Figura 6.29: Valores da concentração dos ácidos acético (•) e propiônico $(\bullet)$ obtidos por cromatografia, do afluente durante o período de operação do ASBBR alimentado com $1943 \pm 205 \mathrm{mg} / \mathrm{L}$ de glicose e 8 horas de ciclo.

Figura 6.30: Valores da concentração dos ácidos acético (•) e propiônico $(\bullet)$ obtidos 52 por cromatografia, do efluente durante o período de operação do ASBBR alimentado com $1943 \pm 205 \mathrm{mg} / \mathrm{L}$ de glicose e 8 horas de ciclo.

Figura 6.31: Alcalinidade a bicarbonato do afluente $(\bullet)$ e efluente $(\bullet)$ durante o 52 período de operação do ASBBR alimentado com $1943 \pm 205 \mathrm{mg} / \mathrm{L}$ de glicose e 8 horas de ciclo.

Figura 6.32: Relação entre a composição molar dos gases $\mathrm{CH}_{4}$ e $\mathrm{CO}_{2}$ durante o 53 período de operação do ASBBR alimentado com $1943 \pm 205 \mathrm{mg} / \mathrm{L}$ de glicose e 8 horas de ciclo.

Figura 6.33: Valores de glicose afluente (๑) e DQO filtrada do afluente $(\bullet)$ e efluente 
(^) e DQO bruta do efluente ( ${ }^{\star}$ ) durante o período de operação do ASBBR alimentado com $495 \pm 35 \mathrm{mg} / \mathrm{L}$ de glicose e 3 horas de ciclo.

Figura 6.34: Eficiência de remoção de DQO total (•) e DQO filtrada (•) durante o período de operação do ASBBR alimentado com $495 \pm 35 \mathrm{mg} / \mathrm{L}$ de glicose e 3 horas de ciclo.

Figura 6.35: Valores da concentração de ácidos totais, obtidos por cromatografia, do afluente $(\bullet)$ e do efluente $(\bullet)$ durante o período de operação do ASBBR alimentado com $495 \pm 35 \mathrm{mg} / \mathrm{L}$ de glicose e 3 horas de ciclo.

Figura 6.36: Valores das concentrações dos ácidos acético (•), propiônico (•) e butírico ( ${ }^{-}$) no efluente obtidos durante o período de operação do ASBBR alimentado com $495 \pm 35 \mathrm{mg} / \mathrm{L}$ de glicose e 3 horas de ciclo.

Figura 6.37: Alcalinidade a bicarbonato do afluente $(\boldsymbol{\bullet})$ e do efluente $(\bullet)$ durante o período de operação do ASBBR alimentado com $495 \pm 35 \mathrm{mg} / \mathrm{L}$ de glicose e 3 horas de ciclo

Figura 6.38: Perfil de DQO (•), glicose $(\bullet)$, AVT pelo método cromatográfico $(\bullet)$, alcalinidade a bicarbonato $(\diamond)$ e potencial redox $(\sigma)$ do ASBBR alimentado com 495 $\pm 35 \mathrm{mg} / \mathrm{L}$ de glicose e 3 horas de ciclo.

Figura 6.39: Concentrações dos AVT, determinado por cromatografia, durante o perfil temporal do ASBBR alimentado com $495 \pm 35 \mathrm{mg} / \mathrm{L}$ de glicose e 3 horas de ciclo.

Figura 6.40: Concentrações dos ácidos acético $(\bullet)$, propiônico $(\bullet)$ e butírico $\left(^{\star}\right)$ 60 durante o perfil temporal do ASBBR alimentado com $495 \pm 35 \mathrm{mg} / \mathrm{L}$ de glicose e 3 horas de ciclo.

Figura 6.41: Valores da alcalinidade a bicarbonato determinado durante o perfil 
temporal do ASBBR alimentado com $495 \pm 35 \mathrm{mg} / \mathrm{L}$ de glicose e 3 horas de ciclo.

Figura 6.42: Perfil da composição de gases, representado como a relação de $\mathrm{CH}_{4} \mathrm{e}$ $\mathrm{CO}_{2}$, no ASBBR alimentado com $495 \pm 35 \mathrm{mg} / \mathrm{L}$ de glicose e 3 horas de ciclo.

Figura 6.43: Valores da concentração glicose afluente (-) e DQO filtrada do afluente $(\bullet)$ e efluente $\left(\wedge^{\bullet}\right)$ e DQO bruta do efluente $\left({ }^{\bullet}\right)$ durante o período de operação do ASBBR alimentado com $990 \pm 72 \mathrm{mg} / \mathrm{L}$ de glicose e 3 horas de ciclo.

Figura 6.44: Eficiência de redução da DQO bruta $(\bullet)$ e filtrada (•) durante o período de operação do ASBBR alimentado com $990 \pm 72 \mathrm{mg} / \mathrm{L}$ de glicose e 3 horas de ciclo.

Figura 6.45: Análise da produção de ácidos voláteis totais, obtidos por 64 cromatografia, do afluente $(\bullet)$ e efluente $(\bullet)$ durante o período de operação do ASBBR alimentado com $990 \pm 72 \mathrm{mg} / \mathrm{L}$ de glicose e 3 horas de ciclo.

Figura 6.46: Valores da concentração dos ácidos acético (•), propiônico (•) e 65 butírico ( ${ }^{\wedge}$ ) obtidos por cromatografia, do efluente durante o período de operação do ASBBR alimentado com $990 \pm 72 \mathrm{mg} / \mathrm{L}$ de glicose e 3 horas de ciclo.

Figura 6.47: Alcalinidade a bicarbonato do afluente $(\bullet)$ e efluente $(\bullet)$ durante o 65 período de operação do ASBBR alimentado com $990 \pm 72 \mathrm{mg} / \mathrm{L}$ de glicose e 3 horas de ciclo.

Figura 6.48: Modelo cinético de primeira ordem ajustado aos dados experimentais de 68 consumo de glicose e de decaimento de DQO ao longo do tempo com ciclo de 8 horas.

Figura 6.49: Modelo cinético de primeira ordem ajustado aos dados experimentais de consumo de glicose e de decaimento de DQO ao longo do tempo com ciclo de 3 horas.

Figura 6.50: Observações morfológicas sob microscopia de contraste de fase e epifluorescência, referentes às amostras do reator ao final da operação com 470 mg/L 
de glicose e com ciclos de 8 horas: (a) filamentos e bacilos delgados,bacilos retos com inclusões e morfologias semelhantes a Methanosarcinas; (b) morfologia semelhante a Methanosarcina; (c) bacilos de dimensões variadas e cocos ovalados; (d) bacilo reto com inclusões; (e) estruras semelhantes a cistos de protozoários; (f). protozoário flagelado.

Figura 6.51: Observações morfológicas sob microscopia de contraste de fase e epifluorescência, referentes às amostras do reator ao final da operação com $852 \mathrm{mg} / \mathrm{L}$ de glicose e ciclos de 8 horas: (a) e (b) morfologias semelhantes a Methanosarcinas, (c) estruturas as bactérias fototróficas anoxigênicas; (d) bacilos fluorescentes; (e) morfologia semelhante a Methanosaeta (f) bacilos de dimensões variadas; (g) filamento de bacilos; (h) filamento septado; (i) bacilo curvo com inclusões; (j) estruturas semelhantes a hifas de fungos e esporos de fungos; (l) estruturas semelhantes a cistos de protozoários; (m) epiroquetas e protozoários flagelados.

Figura 6.52: Observações da coloração Gram nas morfológicas, obtidas por microscopia de contraste de fase, referentes às amostras do reator ao final da operação com $852 \mathrm{mg} / \mathrm{L}$ de glicose e ciclos de 8 horas: (a) estruturas semelhantes a Methanosarcinas, apresentando coloração Gram (-); (b) cocos com coloração Gram (+) estruturas semelhantes a bactérias fototróficas anoxigências apresentando coloração Gram (-); (c) estruturas semelhantes ao filamento de bacilos apresentando coloração Gram (-); (d) Bacilo reto com inclusão Gram (-); (e) cocos Gram (+); (f) estruturas semelhantes a bactérias fototróficas anoxigências apresentando coloração Gram (-).

Figura 6.53: Observações morfológicas sob microscopia de contraste de fase e epifluorescência, referentes às amostras do reator ao final da operação com $495 \mathrm{mg} / \mathrm{L}$ de glicose e ciclos de 3 horas: (a) estruturas semelhantes a Methanosaetas, (b) bacilos de dimensões variadas; (c) bacilos com extremidades arredondadas; (d) estruturas semelhantes a bactérias fototróficas anoxigênicas; (e) bacilos fluorescentes com morfologia semelhante a Arquea methanospirillum, (f) bacilos fluorescentes com morfologia semelhante a arqueas metanogênicas hidrogênotróficas; (g) estruturas semelhantes a endósporos; (h) estruturas semelhantes a cistos de protozoários.

Figura 6.54: Observações da coloração Gram nas morfologias, obtidas por 78 microscopia de contraste de fase, referentes às amostras do reator ao final da 
operação com $495 \mathrm{mg} / \mathrm{L}$ de glicose e ciclos de 3 horas: (a) bacilos com dimensões variadas de coloração Gram (-), bacilos com extremidades arredondas Gram (+) e filamento de bacilos Gram (-), (b) morfologias semelhantes as fototróficas anoxigências Gram (-) e estruturas semelhantes a bacilos retos com inclusão Gram (+); (c) hifa de fungos; (d) bacilos com dimensões variadas de coloração Gram (-), bacilos com extremidades arredondas Gram (+), (e) bacilos de dimensões variadas e filamentos delgadas Gram (-); (f) bacilos Gram (-) agrupados.

Figura 6.55: Observações morfológicas sob microscopia de contraste de fase e epifluorescência, referentes às amostras do reator ao final da operação com 990 mg/L de glicose e ciclos de 3 horas: (a) estruturas semelhantes a endosporos e bacilos de dimensões variadas; (b) filamento de bacilos; (c) estruturas semelhantes a Methanosarcinas; (d) bacilos fluorescentes com morfologia semelhantes a arquea methanogênica hidrogenotróficas; (e) bacilos fluorescentse semelhantes a Arquea methanospirillum; (f) hifas de fungos; (g) filamentos de bacilos; (h) hifas e esporos de fungos.

Figura 6.56: Observações da coloração Gram nas morfologias, obtidas por microscopia de contraste de fase, referentes às amostras do reator ao final da operação com $990 \mathrm{mg} / \mathrm{L}$ de glicose e ciclos de 3 horas; (a) filamentos de bacilos Gram (+); (b) bacilos Gram (-); (c) bacilos Gram (+); (d) filamento septado Gram (-); (e) cocos e bacilos Gram (+); (f) estrutura semelhante ao bacilo curvo com inclusão apresentando coloração Gram (-). 


\section{LISTA DE TABELAS}

Tabela 3.1. Efeito de nutrientes limitantes de crescimento no rendimento da produção de EPS.

Tabela 4.1: Composição de água residuária sintética a ser utilizada.

Tabela 5.1. Resumo das condições operacionais nas duas etapas experimentais.

Tabela 6.1: Médias de DQO, concentrações de glicose, alcalinidade a bicarbonato e ácidos totais $\left(\mathrm{AVT}_{\mathrm{c}}\right.$ e $\left.\mathrm{AVT}_{\mathrm{t}}\right)$ de entrada e saída do ASBBR durante o período de operação com $470 \pm 37 \mathrm{mg} / \mathrm{L}$ de glicose.

Tabela 6.2: Médias de DQO, concentrações de glicose, alcalinidade a bicarbonato e ácidos totais $\left(\mathrm{AVT}_{\mathrm{c}}\right.$ e $\left.\mathrm{AVT}_{\mathrm{t}}\right)$ de entrada e saída do ASBBR durante o período de operação com $852 \pm 190$ mg/L de glicose.

Tabela 6.3: Médias de DQO, concentração de glicose, alcalinidade a bicarbonato e ácidos totais $\left(\mathrm{AVT}_{\mathrm{c}}\right.$ e $\left.\mathrm{AVT}_{\mathrm{t}}\right)$ de entrada e saída do ASBBR durante o período de operação com $1943 \pm 205 \mathrm{mg} / \mathrm{L}$ de glicose.

Tabela 6.4: Médias de DQO, concentração de glicose, alcalinidade a bicarbonato e ácidos totais $\left(\mathrm{AVT}_{\mathrm{c}}\right.$ e $\left.\mathrm{AVT}_{\mathrm{t}}\right)$ de entrada e saída do ASBBR durante o período de operação com $495 \pm 35 \mathrm{mg} / \mathrm{L}$ de glicose e 3 horas de ciclo.

Tabela 6.5: Médias de DQO, concentrações de glicose, alcalinidade a bicarbonato e ácidos totais $\left(\mathrm{AVT}_{\mathrm{c}}\right.$ e $\left.\mathrm{AVT}_{\mathrm{t}}\right)$ de entrada e saída do ASBBR durante o período de operação com $990 \pm 72 \mathrm{mg} / \mathrm{L}$ de glicose e 3 horas de ciclo.

Tabela 6.6: Parâmetros cinéticos obtidos com o ajuste cinético de primeira ordem com concentração de $541 \mathrm{mg} / \mathrm{L}$ de glicose e 8 horas de ciclo.

Tabela 6.7: Parâmetros cinéticos obtidos com o ajuste cinético de primeira ordem com concentração de $942 \mathrm{mg} / \mathrm{L}$ de glicose e 8 horas de ciclo. 
Tabela 6.8: Parâmetros cinéticos obtidos com o ajuste cinético de primeira ordem com concentração de $493 \mathrm{mg} / \mathrm{L}$ de glicose e 3 horas de ciclo.

Tabela 6.9: Diversidade microbiana das amostras de espuma, dos polímeros 72 extracelular retirados na superfície do cesto (SC), dos impelidores que ficam na parte superior (IS) e no fundo do reator (IF), após operação do ASBBR com ciclos de 8 horas.

Tabela 6.10: Diversidade microbiana das amostras de espuma, dos polímeros extracelular retirados na superfície do cesto (SC), dos impelidores que ficam na parte superior (IS) e no fundo do reator (IF), após operação do ASBBR com ciclos de 3 horas. 


\section{LISTA DE ABREVIATURAS}

ASBBR - anaerobic sequencing batch biofilm reactor

ASBR - anaerobic sequencing batch reactor

$\mathrm{C} / \mathrm{N}$ - razão carbono nitrogênio

COV - carga orgânica volumétrica

DQO - demanda química de oxigênio

EPS - polímero extracelular

IF - impelidor da parte inferior ou fundo

IS - impelidor da parte superior

LD - limite de detecção

$\mathrm{SC}$ - superfície do cesto

$\mathrm{SEb}$ - erro padrão do intercepto

UASB - upflow anaerobic sludge blanket 


\section{LISTA DE SÍMBOLOS}

$\mathrm{AB}$ - alcalinidade a bicarbonato

AV - ácidos voláteis específicos obtidos por cromatografia

AVTc - ácidos voláteis obtidos por cromatografia

AVTt - ácidos voláteis obtidos por titulometria

$\mathrm{Cg}$ - concentração de glicose

Cs - concentração de substrato

Cso - concentração de substrato no reator

Csr - concentração de substrato residual

DQOf - demanda química de oxigênio de amostras filtradas

DQOr - porcentagem de remoção da demanda química de oxigênio

DQOt - demanda química de oxigênio total

$\mathrm{k}_{1}{ }^{\text {app }}$ - constante cinética aparente de primeira ordem

SST - sólidos suspensos totais

SSV - sólidos suspensos voláteis

$\mathrm{ST}$ - sólidos totais

STV - sólidos totais voláteis

Valim - volume da alimentação

$\mathrm{V}_{\mathrm{R}}$ - volume do reator 


\section{RESUMO}

MIQUELETO, A. P. (2003). Comportamento de Reator Anaeróbio Operado em Batelada Seqüencial, Contendo biomassa Imobilizada e Submetido a Aumento Progressivo da Concentração de Substrato de Fácil Degradação, Dissertação (Mestrado), Escola de Engenharia de São Carlos, Universidade de São Paulo, 93 p., São Carlos, SP

Os objetivos deste trabalho foram avaliar o desempenho do reator anaeróbio operado em batelada seqüencial quando submetido ao aumento progressivo da concentração de glicose e estimar os parâmetros cinéticos da degradação da glicose. Inicialmente o reator foi operado com ciclos de 8 horas, tratando glicose nas concentrações, aproximadas, de 500, 1000 e 2000 mg/L. Não foi detectada glicose no efluente nas três condições. O reator operou de maneira estável, tratando aproximadamente $500 \mathrm{mg} / \mathrm{L}$ de glicose, com eficiência na remoção da DQO filtrada entre 93\% e 97\%. Na operação com concentrações de glicose no afluente próximas de $1000 \mathrm{mg} / \mathrm{L}$ e $2000 \mathrm{mg} / \mathrm{L}$, observou-se instabilidade operacional, principalmente devido à produção de polímeros extracelulares (EPS) que comprometeram a hidrodinâmica e a transferência de massa no sistema. Os valores médios da concentrações de ácidos voláteis no efluente foram de $159 \pm 72 \mathrm{mg} / \mathrm{L}$ e $374 \pm 92 \mathrm{mg} / \mathrm{L}$, respectivamente. Aos perfis de concentração de glicose foi ajustado modelo de primeira ordem, enquanto que um modelo modificado, contemplando concentração residual de matéria orgânica, foi ajustado aos perfis temporais de DQO. Para verificar a formação do EPS, operou-se o reator com 3 horas de ciclo nas concentrações, aproximadas, de 500 e $1000 \mathrm{mg} / \mathrm{L}$. Esta fase teve como objetivo verificar a hipótese, segundo a qual, a produção de EPS seria resultado da exposição da biomassa a baixas concentrações de matéria orgânica por longo período. Dessa forma, reduzindo o tempo de ciclo, a exposição a baixas concentrações também seria reduzida. No entanto, embora o reator tenha operado com relativa estabilidade, verificou-se formação de grande quantidade de EPS logo na primeira condição operacional, com aproximadamente, $500 \mathrm{mg} / \mathrm{L}$ de glicose no afluente, indicando que a hipótese não estava correta.

Palavras-chave: tratamento de águas residuárias, reator operado em batelada seqüencial, ASBBR, polímeros extracelulares, EPS, glicose, espuma de poliuretano. 


\begin{abstract}
MIQUELETO, A.P. (2003). Behavior of the Anaerobic Sequencing Batch Reactor Containing Immobilized Biomass and Submitted to a Progressive Increasing of the Concentration of Easy Degradation Substrate, Dissertação (Mestrado), Escola de Engenharia de São Carlos, Universidade de São Paulo, 93 p., São Carlos, SP
\end{abstract}

The main objectives of this study were to evaluate the performance of the anaerobic sequencing batch reactor when subjected to a progressive increasing of the influent glucose concentration and estimate the kinetic parameters of glucose's degradation. Initially the reactor was operated with 8-hour cycles, treating glucose at concentrations of 500, 1000 and $2000 \mathrm{mg} / \mathrm{L}$. Glucose was not detected in the effluent in all these three conditions. The reactor showed operating stability treating glucose concentration of approximately $500 \mathrm{mg} / \mathrm{L}$, with efficiencies between $93 \%$ to $97 \%$ in the filtrated COD removal. In the operation with glucose concentrations of $1000 \mathrm{mg} / \mathrm{L}$ and $2000 \mathrm{mg} / \mathrm{L}$, approximately, it could be noticed an operational instability, caused mainly by a production of extracellular polymers (EPS) leading to hydrodynamic and mass transfer problems in the reactor. The mean values of volatile acids concentration in the effluent were about $159 \pm 72 \mathrm{mg} / \mathrm{L}$ and $374 \pm 92 \mathrm{mg} / \mathrm{L}$, respectively. A first order model was adjusted to glucose concentration profiles, and a modified model, including a residual concentration of substrate, was adjusted to COD temporal profiles. To verify the EPS formation, the reactor was operated with 3-hour cycle in the concentrations of 500 and $1000 \mathrm{mg} / \mathrm{L}$ This stage had the objective of verifying if the EPS production would result from the exposure of the biomass to low concentration of substrate for a long period of time. Thus, reducing the time cycle, the exposure to low concentrations would also be reduced. Nevertheless, even with the reactor operating with relative stability, the hypotheses could not be verified due the formation of a large amounts of EPS right in the first operational condition with approximately to $500 \mathrm{mg} / \mathrm{L}$ of glucose in the influent, showing that the hypothesis was not right.

Key words: residual water treatment, reactor operated in sequencing batch, ASBBR, extracellular polymers, EPS, glucose, polyurethane foam. 


\section{INTRODUÇÃO}

A biotecnologia anaeróbia para tratamento de águas residuárias tem se desenvolvido de forma extraordinária com a introdução de reatores contendo biomassa imobilizada. Essa imobilização ocorre através da formação de um biofilme aderido a um material suporte ou pela formação de lodo granular. A principal diferença desses reatores em relação aos convencionais é propiciar operação com tempos de retenção celular elevados, mesmo quando operando a baixos tempos de detenção hidráulica, resultando em diminuição do volume reacional, tornando-os mais viáveis economicamente.

Apesar do lodo granular e biofilmes aderidos serem atualmente extensivamente estudados, parâmetros fundamentais para simulação, otimização e aumento de escala de reatores anaeróbios heterogêneos são raramente encontrados na literatura. Na verdade, a maior parte dos reatores biológicos tem sido projetada baseando-se em critérios empíricos. No entanto, a aplicação de tais critérios resulta, na maior parte dos casos, em unidades nãootimizadas, e até mesmo inadequadas para se atingir os objetivos propostos. Portanto, o desenvolvimento de critérios racionais de projeto é de extrema importância para a modelagem, otimização e simulação deste tipo de processo.

Dentre as novas configurações propostas para reatores anaeróbios aplicados ao tratamento de águas residuárias estão os reatores anaeróbios em batelada seqüencial (SUTHAKER, et al., 1991; DAGUE et al., 1992; FERNANDES et al., 1993; SUNG \& DAGUE, 1995; ANGENENT \& DAGUE, 1995; DROSTE \& MASSÉ, 1995; BRITO et al., 1997, TIMUR \& ÖSTURK, 1999), que apresentam grandes vantagens e potencial de utilização em escala industrial. Nesse sentido, a Escola de Engenharia de São Carlos - USP e a Escola de Engenharia Mauá (EEM) iniciaram projeto conjunto de pesquisa enfocando a otimização e novas propostas para estudar a viabilidade da aplicação dos processos em batelada, em escala real.

Os reatores anaeróbios operados em batelada seqüencial foram originalmente propostos para operação com biomassa granulada (auto-imobilizada) e as etapas de operação compreendiam enchimento, reação, sedimentação e descarga do meio líquido. Como, em muitos trabalhos, o tempo de sedimentação era alto em relação ao tempo total e, muitas 
vezes a retenção de sólidos no sistema era insatisfatória, surgiu a proposta de uma configuração contendo suporte inerte para imobilização da biomassa com o objetivo de suprimir a etapa de sedimentação e, conseqüentemente, de reduzir o tempo total de ciclo. Além disso, a imobilização da biomassa visava melhor retenção de sólidos no reator.

Os avanços conseguidos com a utilização de reatores em batelada agitados mecanicamente e contendo biomassa imobilizada em matrizes de espuma de poliuretano, inicialmente proposto por RATUSZNEI et al. (2000), permitem vislumbrar a aplicação para extensa gama de águas residuárias. Entretanto, estudos mais aprofundados devem ser realizados com a finalidade de avaliar a real aplicabilidade desse tipo de sistema. Dentre os temas mais importantes está a avaliação do comportamento desses reatores quando submetidos a aumentos progressivos de cargas orgânicas a fim de se estabelecer os limites para aplicação prática.

A aplicação dos reatores anaeróbios operados em batelada seqüencial, contendo microrganismos imobilizados em suporte fixo, depende ainda do entendimento de muitos aspectos fundamentais e tecnológicos. Dentre os aspectos fundamentais podem ser destacados os fenômenos de transferência de massa, o comportamento cinético, além do comportamento hidrodinâmico. Com relação aos aspectos técnicos, estes incluem avaliações operacionais de tais sistemas e a aplicabilidade para tratamento de águas residuárias variadas.

Dentro do escopo tecnológico, este trabalho está direcionado à avaliação das cargas orgânicas aplicáveis nesses reatores quando empregado no tratamento de águas residuárias de fácil degradação. Tais despejos podem, potencialmente, causar problemas operacionais devido às altas velocidades de acidificação, pois dependem da eficiência do sistema de retenção de biomassa que garanta equilíbrio entre as populações produtoras e consumidoras de ácidos orgânicos e $\mathrm{H}_{2}$. De acordo com BAGLEY \& BRODKORB (1999), os processos anaeróbios em batelada deveriam estar mais susceptíveis ao desbalanceamento quando fossem aplicados no tratamento de águas residuárias de fácil degradação.

Neste trabalho foram avaliados estabilidade e desempenho de reator anaeróbio operado em batelada seqüencial e contendo biomassa imobilizada, o qual foi alimentado com água residuária de fácil degradação (contendo glicose) e submetido a aumento progressivo da carga orgânica. 


\section{OBJETIVOS}

O objetivo principal deste trabalho foi a avaliação operacional do reator anaeróbio operado em batelada seqüencial e contendo biomassa imobilizada, tratando água residuária de fácil degradação, no caso glicose, quando submetido a aumentos progressivos da carga orgânica.

Os objetivos específicos foram:

- Estudo cinético da degradação da glicose;

- Verificar a produção dos polímeros extracelular, operando o reator com menor tempo de ciclo;

- Análise da população microbiana do reator. 


\section{REVISÃO BIBLIOGRÁFICA}

\subsection{Reator Anaeróbio em Batelada Seqüencial (ASBR)}

Reatores anaeróbios em batelada vêm recebendo maior atenção nos últimos anos, estando o seu uso prático voltado para o tratamento de águas residuárias em geral. Embora ainda em estágio de desenvolvimento, seu uso se revela promissor, uma vez que os resultados demonstraram que esse tipo de reator é também adequado para efluentes de baixas concentrações, como é o caso dos esgotos sanitários, e também para operação em temperaturas mais baixas. Segundo SCHMIT \& DAGUE (1993), quando resíduos da atividade de suinocultura foram tratados a $20^{\circ} \mathrm{C}, 25^{\circ} \mathrm{C}$ e $35^{\circ} \mathrm{C}$ em reator anaeróbio sequiencial em batelada, as temperaturas mais baixas foram compensadas com maiores tempos de retenção de sólidos. Dentro de certos limites no ASBR (anaerobic sequencing batch reactor), a queda de temperatura pode ser compensada com o aumento da concentração da biomassa (DAGUE et al. 1992).

Segundo SPEECE (1996), o ASBR seleciona as metanogênicas que crescem em baixas concentrações de ácidos voláteis. Esse é um princípio importante que permite obter concentrações de ácidos graxos mais baixas no ASBR.

De acordo com DAGUE et al. (1992), a característica básica do reator operado em batelada seqüencial é ser carregado inicialmente com água residuária e esvaziado ao final do tratamento, repetindo-se a operação com nova batelada. O conteúdo no interior do reator é misturado, permitindo o contato efetivo entre o esgoto e a biomassa. O tratamento é efetuado em tanque único, em seqüência operacional que compreende basicamente as seguintes fases: i) enchimento com água residuária, ii) tratamento propriamente dito, por meio das reações ou transformações dos constituintes do esgoto por microrganismos; iii) sedimentação final do lodo biológico, após a finalização das reações; iv) esvaziamento do tanque, com a retirada do líquido tratado e clarificado. A Figura 3.1 mostra as etapas do reator operado em batelada. 

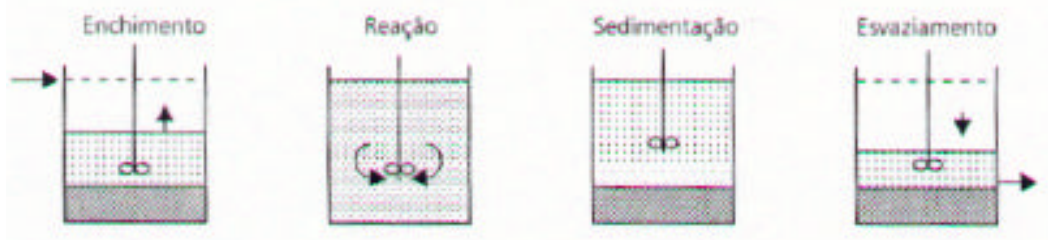

Figura 3.1: Etapas de operação do reator em batelada (DAGUE et al., 1992).

O ASBR não necessita de sistemas de alimentação complexos devido à configuração que permite a disposição uniforme da biomassa no reator. Desse modo, as possibilidades de ocorrência de caminhos preferenciais, curtos-circuitos e zonas estagnadas são consideradas mínimas (ANGENENT \& DAGUE, 1995).

A fase de reação é a mais importante do processo, pois é nela que a maior parte da matéria orgânica presente na água residuária é convertida a $\mathrm{CH}_{4} \mathrm{e} \mathrm{CO}_{2}$, representando muitas vezes, $80 \%$ ou mais do tempo do ciclo total (HOLLOPETER \& DAGUE, 1994). O tempo gasto nessa etapa depende da composição da água residuária, da quantidade de sólidos presentes, da carga orgânica, da concentração da biomassa, da temperatura e da qualidade exigida do efluente (SUNG \& DAGUE, 1995).

O tempo necessário para a etapa de sedimentação requer de poucos minutos a algumas horas. Segundo estudos realizados por HOLLOPETER \& DAGUE, 1994, o tempo de sedimentação pode representar até $15 \%$ do tempo total gasto na operação. A duração dessa etapa dependerá da concentração de substrato, concentração da biomassa e da temperatura da água residuária (ANGENENT \& DAGUE, 1995), sendo essas características, portanto, de fundamental importância no desempenho do sistema.

A intensidade da agitação da biomassa e do substrato durante a etapa de reação também é importante, pois a agitação não pode ser muito intensa para não destruir os grânulos.

Esse tipo de reator apresenta vantagens importantes em relação a outros reatores anaeróbios. Nele é possível conseguir baixa razão substrato/microrganismos (favorecendo a floculação biológica e a sedimentação) e, ao mesmo tempo, processar esgoto a altas velocidades de reação. A concentração de substrato é maior logo após a alimentação, diminuindo com o tempo de reação; no entanto, antes da nova fase de alimentação a concentração do substrato é mais baixa nesse reator do que em um sistema contínuo. Dessa forma, em reatores em batelada, a formação de grânulos, a biodegradação e a capacidade de sedimentação podem ser mais eficientes que nos sistemas contínuos.

Se comparado com reator semelhante de alimentação contínua, em geral, o volume do ASBR é maior. No entanto, o reator descontínuo não há necessidade da existência de 
sedimentador em separado e de recirculação externa de lodo biológico (SPEECE, 1996). É atribuída a esse reator anaeróbio seqüencial uma semelhança com o reator anaeróbio de manta de lodo e escoamento ascendente (UASB) nos aspectos de biomassa formada, com boas características de sedimentação, com desenvolvimento de lodo denso ou mesmo granular. A presença de lodo denso no reator significa menor perda de sólidos biológicos com o efluente durante a operação de descarga.

No Brasil, esse processo vem sendo estudado como uma alternativa para os processos contínuos de tratamento anaeróbio por pesquisadores do Instituto de Pesquisas Hidráulicas da Universidade Federal do Rio Grande do Sul (IPH - UFRGS), da Escola de Engenharia Mauá e da EESC-USP no Departamento de Hidráulica e Saneamento, em escala de bancada. Os primeiros resultados apontam para um bom desempenho desses reatores no tratamento de esgotos sintéticos com características semelhantes às dos esgotos sanitários. No entanto, estudos visando a aplicação de tais processos para tratamento de águas residuárias industriais são escassos na literatura.

O desenvolvimento e o estudo de reatores anaeróbios em batelada é muito recente e os resultados obtidos até o momento podem ser considerados apenas indicativos e não conclusivos. A aplicação em escala industrial desse tipo de tecnologia ainda está distante, pois diversos fenômenos fundamentais e aspectos tecnológicos ainda devem ser elucidados. A aplicação de processos descontínuos em tratamento anaeróbio de águas residuárias é apropriada nos seguintes casos (ZAIAT, et al., 2001):

- Indústrias que lançam efluentes de forma intermitente ou atividades que geram efluentes apenas em algumas épocas do mês ou do ano.

- Indústrias que trabalham com padrões de lançamento muito restritivos ou com compostos de difícil degradação; neste caso, a qualidade do efluente pode ser controlada lançando-o no ambiente apenas quando os padrões forem atingidos ou quando o composto tóxico tiver sido satisfatoriamente degradado.

- Sistemas que visam o reuso de águas residuárias ou de substâncias nelas dissolvidas. $\mathrm{O}$ controle sobre a reutilização das águas pode ser maior e melhor do que em sistemas contínuos.

- Em trabalhos fundamentais que visam a elucidação de alguns fenômenos da degradação anaeróbia, devido à facilidade de instrumentação e controle.

A capacidade dos reatores anaeróbios em batelada seqüencial tem sido estudada para tratar resíduos de atividades de suinocultura (SCHMIT \& DAGUE, 1993, ZHANG et al, 1997; ANGENENT et al. 2002), lodo de estações de tratamento (CHANG et al, 1994) e água residuária de baixa concentração (NDON \& DAGUE, 1997; DAGUE et al, 1998) água 
residuária de abatedouro de aves (MASSÉ \& MASSE, 2000).

\subsection{Estudos Realizados com o ASBR Utilizando Glicose ou Sacarose como}

\section{Substrato}

BAGLEY \& BROSKORB (1999) realizaram estudos em ASBR tratando glicose, em diferentes concentrações e tipos de alimentação. Foram estudadas três condições diferentes. A primeira foi o controle, na qual a concentração de glicose foi de $2000 \mathrm{mg} / \mathrm{L}$, expressa como demanda química de oxigênio (DQO), com tempo de ciclo de 24 horas e rápido tempo de enchimento (24 minutos). No segundo caso as condições operacionais foram as mesmas, porém a concentração foi de $4000 \mathrm{mg} \mathrm{DQO} / \mathrm{L}$. Na terceira condição a concentração foi de $2000 \mathrm{mg}$ DQO/L, mas o tempo de alimentação foi de 16 horas.

Os resultados obtidos no primeiro caso indicaram que a concentração de glicose aumentou rapidamente com o rápido tempo de enchimento e foi degradada durante $4 \mathrm{~h}$ aproximadamente. A produção de ácidos voláteis ocorreu paralelamente ao consumo de glicose, no entanto, com degradação muito mais lenta. Ocorreu acúmulo significativo de ácidos voláteis durante o ciclo: do valor inicial de $250 \mathrm{mg}$ DQO/L houve aumento para 500 mg DQO/L, indicando que o reator não estava sendo operado de forma estável para esta concentração. $\mathrm{O}$ ácido láctico foi o primeiro produto a ser formado com o consumo da glicose, embora frações significativas de ácido propiônico e butírico também tenham sido observadas, sendo menor a fração de ácido butírico. Depois do consumo da glicose estar completo, a degradação do ácido láctico continuou formando ácido propiônico e acético, levando em torno de 4 horas. O ácido propiônico acumulou até o ácido láctico ser consumido e então começou a ser lentamente degradado, levando em torno de 16 horas.

No segundo caso a transformação da glicose para ácido láctico foi mais lenta, em torno de 8 horas, e a degradação de ácido láctico também ( 8 horas). Houve acúmulo de ácidos, em torno de $1000 \mathrm{mg} \mathrm{DQO} / \mathrm{L}$, ao final das 24 horas do ciclo. No terceiro caso, a produção dos ácidos acético, propiônico, butírico e láctico ocorreram paralelamente, porém os ácidos láctico e butírico atingiram menores concentrações, aproximadamente $200 \mathrm{mg}$ $\mathrm{DQO} / \mathrm{L}$.

SHIZAS \& BAGLEY (2001) também realizaram estudos utilizando glicose como fonte de carbono em diferentes concentrações e tempo de ciclos. Inicialmente estudou-se o tratamento de água residuária com concentração de glicose de $4000 \mathrm{mg} / \mathrm{L}$ com tempo de ciclo de 24 horas obtendo uma eficiência de remoção da DQO solúvel entre 70 e 80\%. Em seguida, aumentou-se a concentração de glicose para $6000 \mathrm{mg} / \mathrm{L}$ com tempo de ciclo de 48 
horas. Nesse caso, ocorreu a formação imediata dos ácidos propiônico, acético e láctico. O ácido láctico produzido foi degradado uma hora após o enchimento do reator, porém a remoção do ácido propiônico e acético foi menor que $25 \%$ até o final do ciclo. O ácido butírico foi formado durante esse tempo, mas em concentração abaixo de $100 \mathrm{mg}$ DQO/L. Com $3000 \mathrm{mg}$ glicose/L e tempo de ciclo de 24 horas, também foi observada rápida acidificação, devido aos ácidos propiônico e acético, cujos acúmulos foram menores.

SUTHAKER et al. (1991) testaram o desempenho do ASBR com várias estratégias de alimentação, utilizando glicose com água residuária na concentração de $35000 \mathrm{mg}$ DQO/L. O reator foi operado com cinco relações diferentes de tempo de enchimento e tempo de reação (F/R). Os tempos dos ciclos variaram de 4, 8, 12 e 16 dias. O reator alcançou 73\% na remoção de DQO solúvel com o tempo de ciclo de 16 dias e relação F/R igual a 1/3, e 53\% com tempo de ciclo de 12 dias e relação F/R de 1:1.

ANGENENT \& DAGUE (1995) fizeram estudo comparativo do ASBR com UASB aumentando a carga de sacarose. A carga orgânica volumétrica inicial, em ambos os reatores, foi de 6 g/L.d. O tempo de ciclo do ASBR foi de $4 \mathrm{~h}$ com tempo de enchimento de 11,5 minutos e o tempo de detenção hidráulica do UASB foi de 12 horas. A carga era aumentada quando os testes indicavam esta possibilidade.

Os autores observaram que o desempenho do UASB submetidos a altas cargas orgânicas foi melhor do que a baixas. A carga máxima de DQO no ASBR atingiu 19 g/L.d, contra $21 \mathrm{~g} / \mathrm{L} . d$ para o UASB. A remoção da DQO solúvel aumentou continuamente durante os primeiros 40 dias de operação, atingindo valores de 95\%. A concentração de ácidos voláteis foi menor no UASB, quando os reatores foram operados em altas cargas de DQO. Operando o ASBR com carga volumétrica de 19 g/L.d, a concentração de ácidos voláteis, como ácido acético, no efluente, foi menor que $400 \mathrm{mg} / \mathrm{L}$. Porém, os autores concluíram que o desempenho do processo em batelada pode ser melhorado mudando-se as condições operacionais, com maior tempo de alimentação ou menores tempos de ciclos.

O desempenho do UASB com alimentação contínua foi superior ao do ASBR com altas cargas de matéria orgânica. A concentração de ácidos voláteis foi mais baixa e a remoção da DQO solúvel foi mais favorável no UASB. No entanto, o tempo de ciclo do ASBR foi de somente 4 horas comparado ao TRH de 12 horas do UASB.

Em estudos preliminares realizados por BRITO, et al. (1997), tratando água residuária sintética contendo $10 \%$ de glicose e $90 \%$ de ácido acético, propiônico e butírico com DQO próxima de $1000 \mathrm{mg} / \mathrm{L}$, foram observadas eficiências de remoção de DQO entre 60 e $70 \%$ com tempos de reação de 5 e 6 horas. 


\subsection{Biomassa Imobilizada em Espuma de Poliuretano}

A aderência dos microrganismos em material suporte depende das propriedades físico-químicas do suporte (ROUXHET \& MOZES, 1990¹ apud ALVES, et al., 1999). De acordo com HUYSMAN et al. (1983) as superfícies porosas e rugosas são mais propícias que as lisas, além do tamanho e do número de poros influenciarem no resultado final da formação do biofilme. As características da água residuária devem ser consideradas, pois poderá haver interação com o suporte, além de interferências diretas na adesão microbiana (MUÑOZ, et al., 1994).

ALVES et al. (1999) realizaram estudos para determinar a atividade metanogênica específica da biomassa aderida em vários suportes e compararam com a biomassa livre. Os suportes utilizados foram: argila, lã de vidro, pozolana e sepiotito. Os resultados mostraram que a atividade metanogênica da biomassa fixa foi menor que na livre. Esses resultados indicaram ter havido limitação na disponibilidade do substrato, principalmente onde se desenvolveram biofilmes mais espessos nos suportes. Na tentativa de determinar quais grupos de bactérias foram mais afetados pela imobilização, foram determinadas as velocidades de degradação de acetato, butirato e propionato para os diferentes suportes e para biomassa livre. Os resultados mostraram estímulo na degradação do butirato e propionato para a biomassa imobilizada, indicando que a criação dos microambientes, decorrente da imobilização, exerceu efeito positivo na atividade simbiótica necessária entre os diferentes microrganismos participantes da digestão anaeróbia.

HUYSMAN et al. (1983), testando vários tipos de suportes porosos e não porosos para biomassa metanogênica, verificaram que a espuma de poliuretano reticulada foi colonizada rápida e densamente. A porosidade e o diâmetro dos poros parecem ser de primordial importância na colonização microbiana, uma vez que interferem na difusão do substrato dentro da partícula.

FYNN \& WHITMORE (1984) analisaram a colonização de cultura enriquecida com arqueas metanogênicas em espumas de poliuretano variando a porosidade entre 20 a 60 poros por polegada linear. Foi utilizado um reator de mistura alimentado com formiato de sódio, única fonte de carbono. Os autores constataram que a colonização da espuma aumenta com o aumento do número de poros.

CALZADA et al. (1984) estudaram a degradação de efluente de polpa de café acidificada, rico em açúcares, em reatores metanogênicos de leito fixo, recheado com

\footnotetext{
${ }^{1}$ Rouxhet, P. G., and Mozes, N. (1990).Physical Chemistry of the Interface Between Attached Microorganisms and Their Support. Water Sci. Techonol. (G.B.) 22, 1.
} 
espuma de poliuretano. Os resultados obtidos mostraram que a espuma de poliuretano é adequada para a retenção de biomassa em reatores tratando esse tipo de efluente. Houve também uma satisfatória conversão da matéria orgânica em metano.

GIJZEN et al. (1988) usaram espuma de poliuretano como material suporte na imobilização de associações metanogênicas para tratar resíduos sólidos finamente particulados. A colonização no reator alimentado com uma mistura de acetato, propionato e butirato foi rápida e densa, composta, principalmente, por longos filamentos de arqueas do tipo Methanosaeta e um pequeno número de Methanosarcina sp.

ZAIAT et al. (1996) realizaram estudos em reator anaeróbio horizontal de leito fixo (RAHLF) contendo espuma de poliuretano utilizando glicose com substrato. Foi avaliado o arraste de células das matrizes de espuma e determinados os coeficientes de transferência de massa na fase líquida e sólida. Trabalhando com a velocidade superficial de $2,21 \mathrm{~cm} / \mathrm{s}$, somente 9\% dos sólidos voláteis suspensos foram arrastados das matrizes de espuma. A resistência à transferência de massa externa pode ser diminuída operando-se o reator com velocidade superficial de líquido adequada.

VARESCHE et al (1997) constataram que microrganismos aderem com firmeza às matrizes de poliuretano, provavelmente devido à formação de algum tipo de ligação. Tais ligações estão relacionadas com forças de dupla camada eletrônica entre as células e o suporte inerte, forças de van der Waals e ligações químicas como já observado por SANCHEZ et al. (1994). HUYSMAN et al. (1983), FYNN \& WHITMORE (1984), GIJZEN et al. (1988), indicando que os agregados microbianos ficam retidos nos poros das espumas de poliuretano de forma mecânica ou física. Esses fatos levaram VARESCHE et al. (1997) a concluir que culturas mistas de lodo anaeróbio se aderem melhor a esse tipo de suporte do que culturas predominantemente metanogênicas. A conformação da biomassa pareceu otimizar os fluxos de substratos primários e produtos intermediários entre as espécies dentro das matrizes.

RIBEIRO (2001) estudou a influência do tipo de substrato na dinâmica de formação do biofilme em matrizes de espuma de poliuretano em reatores anaeróbios horizontais de leito fixo diferenciais, alimentados com extrato de carne, glicose, amido e lipídeos e com substrato complexo. A influência do substrato na dinâmica de aderência microbiana foi constatada devido aos diferentes padrões de colonização encontrados. Verificou-se que a excreção de polímeros pareceu ser de fundamental importância no processo de colonização das matrizes de poliuretano, estando vinculada, provavelmente, à fixação de células ao suporte. Partidas rápidas observadas em trabalhos utilizando reatores de leito fixo e espuma de poliuretano como suporte podem estar vinculadas à rápida aderência dos organismos a 
esse suporte.

\subsection{Estudos em Reatores Anaeróbios em Batelada Seqüencial Contendo Células Imobilizadas (ASBBR)}

Novas configurações de reatores anaeróbios descontínuos são alternativas para solução de problemas relacionados à aplicação de tais reatores. Por exemplo, a utilização de suportes inertes pode melhorar a retenção de biomassa e, assim, a fase de sedimentação, com a redução de tempo do ciclo total. A imobilização em suporte inerte pode eliminar as incertezas quanto ao processo de granulação.

O reator proposto por RATUSZNEI et al. (2000), em escala de bancada, composto por frasco de vidro cilíndrico (volume: 2 litros), e provido de agitador magnético, responsável pela homogeneização e mistura. Espumas de poliuretano com biomassa anaeróbia imobilizada foram confinadas em uma espécie de cesto no interior do sistema. O reator, mantido a $30^{\circ} \mathrm{C}$, atingiu estabilidade operacional após 10 dias de experimento, tratando 0,5 litro de esgoto sanitário sintético (480 mg DQO/L) com 3 ciclos/dia (ciclo: 8 horas). A máxima eficiência de remoção em termos de DQO de $86 \%$ foi alcançada depois de 36 dias de operação, com apenas 3 horas do início do ciclo.

RATUSZNEI et al. (2002) verificaram a influência da estratégia de alimentação na estabilidade e no desempenho desse sistema. O reator foi operado com tempo de ciclos de 3 horas, tratando esgoto sintético com $500 \mathrm{mg}$ DQO/L, com tempo de enchimento de 3 minutos (batelada) e batelada alimentada com tempos de enchimento de 30, 60 e 180 minutos. A eficiência de remoção nos testes em batelada foi de $86 \%$. Na batelada alimentada, o sistema alcançou a estabilidade somente com o tempo de enchimento de 30 minutos. Nesse sistema foi observada a formação de grande quantidade de polímero extracelular, provavelmente, segundo os autores, pela condição de stress imposta à biomassa que permanecia grande parte do ciclo sem contato com o substrato.

A aplicação dos reatores anaeróbios em batelada seqüencial contendo microrganismos imobilizados em suporte fixo depende ainda do entendimento de muitos aspectos fundamentais e tecnológicos. Dentre os aspectos fundamentais podem ser destacados os fenômenos de transferência de massa, o comportamento cinético, além do comportamento hidrodinâmico.

Os efeitos da transferência de massa na fase sólida foram avaliados por CUBAS et al., (2002) no ASBBR (anaerobic sequencing batch biofilm reactor), em escala de bancada. Diferentes condições de transferência massa na fase sólida foram impostas, variando-se o 
tamanho de cubos de espuma de poliuretano de 0,5, 1,0, 2,0 e 3,0 cm de aresta. O reator foi alimentado com substrato sintético, com ciclos de 8 horas e agitação constante de 500 rpm. A transferência de massa na fase sólida não foi o passo limitante na conversão da matéria orgânica com partículas entre $0,5 \mathrm{~cm}$ a $2,0 \mathrm{~cm}$ de aresta. A resistência à transferência de massa somente influenciou na velocidade de degradação da matéria orgânica com cubos de espumas de 3,0 cm de aresta.

PINHO et al. (2002) estudaram a influência da velocidade de agitação no tratamento de efluentes parcialmente solúveis, em ASBBR contendo biomassa fixa em partículas cúbicas de espuma de poliuretano de 3,0 $\mathrm{cm}$ de aresta. O substrato utilizado foi leite de soja com $45 \%$ da DQO na forma de matéria suspensa. O reator foi operado com ciclos de 8 horas e agitação constante. As velocidades de agitação foram: 500 rpm, 700 rpm, 900 rpm e 1100 rpm. O tempo de mistura, de 90 segundos, foi muito baixo se comparado com o tempo de ciclo, indicando que o sistema pode ser considerado como de boa mistura com velocidades de agitação entre 500 e $1000 \mathrm{rpm}$. Foi observado também que a concentração residual de substrato diminuiu quando a velocidade de agitação foi aumentada, afetando positivamente a qualidade do efluente tratado.

Os avanços conseguidos nos vários trabalhos citados com a utilização de reatores em batelada, contendo biomassa imobilizada em matrizes de espuma de poliuretano, permitem vislumbrar a aplicação para uma extensa gama de águas residuárias. Entretanto, estudos mais aprofundados devem ser realizados com a finalidade de avaliar a real aplicabilidade desse tipo de sistema. Dentre os temas mais importantes está a avaliação do comportamento de tais sistemas quando submetidos a aumentos progressivos de cargas orgânicas a fim de se estabelecer os limites para aplicação prática do sistema.

Dentro do escopo tecnológico, este trabalho está direcionado à avaliação das cargas orgânicas aplicáveis nesses sistemas quando empregado no tratamento de águas residuárias de fácil degradação.

\subsection{Estudos Cinéticos em Reatores em Batelada Seqüencial com Células Imobilizadas (ASBBR)}

CUBAS et al (2002) realizou estudos cinéticos com dados obtidos experimentalmente, com o objetivo de avaliar os efeitos da transferência de massa na fase sólida, e observou-se que a estes se ajustou o modelo de primeira ordem modificado descrito na equação 3.1: 
$C_{S}=C_{S_{R}}+\left(C_{S_{0}}-C_{S_{R}}\right) e^{-k_{1}^{a p p} . t}$

A equação 3.1 é análoga ao modelo cinético de primeira ordem, porém é considerada a concentração do substrato residual $\left(\mathrm{C}_{\mathrm{SR}}\right)$, parâmetro diretamente associado com a qualidade final do efluente. $\mathrm{C}_{\mathrm{S}}$ é a concentração do substrato no meio líquido, t é o tempo e $\mathrm{C}_{\mathrm{So}}$ é a concentração inicial do substrato no meio líquido do reator, no tempo igual a zero. $\mathrm{K}_{1}^{\text {app }}$ é a constante cinética aparente de primeira ordem.

Os valores da constante cinética aparente de primeira ordem foram estimados em $0,59 \pm 0,01 \mathrm{~h}^{-1}$ para os experimentos com biopartículas entre 0,5 e $2,0 \mathrm{~cm} \mathrm{e} 0,48 \mathrm{~h}^{-1} \mathrm{em}$ experimentos com biopartículas de $3,0 \mathrm{~cm}$. A concentração do substrato residual $\left(\mathrm{C}_{\mathrm{SR}}\right)$ aumentou exponencialmente quando se aumentou o tamanho das biopartículas de $0,5 \mathrm{~cm}$ a 3,0 cm. Portanto, a qualidade o efluente melhorou quando o tamanho das biopartículas diminuiu, como resultado da diminuição da resistência na transferência de massa na fase sólida.

A influência da velocidade de agitação no tratamento de efluentes parcialmente solúveis, em ASBR com biomassa fixa em espuma de poliuretano, foi avaliada por PINHO et al (2002). O efeito cinético da velocidade de agitação também foi analisado ajustando o modelo cinético de primeira-ordem modificado (eq. 3.1). A constante cinética aparente de primeira ordem para DQO suspensa aumentou aproximadamente $360 \%$ quando a velocidade da agitação foi mudada de $500 \mathrm{rpm}$ para $900 \mathrm{rpm}$, enquanto que o $\mathrm{k}_{1}{ }^{\text {app }}$ para a DQO solúvel não variou significativamente. No entanto, a concentração residual total do substrato diminuiu continuamente com o aumento da velocidade da agitação, principalmente devido a redução na concentração residual do substrato referente à matéria orgânica particulada.

Dos estudos cinéticos realizados com ASBR contendo biomassa imobilizada em espuma de poliuretano pôde-se observar que o modelo cinético de primeira ordem modificado (eq. 3.1) se ajustou muito bem aos dados experimentais de degradação da matéria orgânica.

BAGLEY \& BRODKORB (1999) investigaram a capacidade do ASBR em suportar sobrecargas orgânicas, desenvolvendo um modelo cinético de simulação que foi validado experimentalmente. $\mathrm{O}$ modelo considera diferentes populações microbianas na comunidade anaeróbia, prevê a formação e consumo de produtos intermediários em função da pressão parcial de hidrogênio, prevê a variação do $\mathrm{pH}$ do sistema e considera inibições causadas pelo pH e pela pressão parcial de hidrogênio. Os resultados experimentais, utilizando um ASBR em escala de laboratório alimentado com glicose, corresponderam aos resultados obtidos 
com o modelo de simulação. O sistema de equações foi resolvido numericamente usando o algoritmo Rung-Kutta Cash-Karp de quinta-ordem. A constante de primeira ordem de consumo da glicose foi de $0,02 \mathrm{~d}^{-1}$.

\subsection{Exopolissacarídeo (EPS) ou Polímero Extracelular}

No tratamento em escala real de águas residuárias contendo compostos de fácil degradação como a glicose, a formação do EPS pode interferir de modo a inviabilizar o tratamento biológico. Tais problemas estão relacionados com a hidrodinâmica do sistema e, conseqüentemente, com a transferência de massa.

A maioria das bactérias produz polímeros extracelulares que participam na formação de agregados microbiológicos (GEESEY, $1982^{3}$ apud CHRYSI \& BRUCE, 2002). Algumas das funções do EPS são: a aderência em superfícies, a agregação de bactérias em flocos ou biofilmes, a estabilização da estrutura do biofilmes, a formação de uma barreira de proteção que aumenta a resistência contra efeitos considerados agressivos às células, a retenção de água, a sorção de compostos orgânicos exógenos para a acumulação de nutrientes que provêm do meio, o acúmulo de enzimas, assim como a digestão de macromoléculas exógenas para aquisição de nutrientes. Um novo conceito é que o EPS é um meio que permite a cooperação e a comunicação entre células e agregados microbiológicos (CHRYSI \& BRUCE, 2002).

Biofilmes são sistemas heterogêneos constituídos por células bacterianas embebidas em uma matriz de substâncias poliméricas extracelulares (EPS), parecidas com gel, cuja a massa é devida, principalmente, à água e sais. O EPS é produto de metabólitos das bactérias e consistem em componentes poliméricos como polissacarídeos, proteínas, ácidos nucleicos e outros (KÖRSTGENS, et al., 2001). Segundo CHRYSI, \& BRUCE (2002), as proteínas são o fator chave para a estabilização da estrutura do agregado, pois seus aminoácidos, negativamente carregados, devem estar mais envolvidos em ligações eletrostáticas com cátions multivalentes, do que açúcares. Uma segunda função chave da proteína extracelular é como enzima responsável pela digestão de macromoléculas e de materiais particulados no micro-ambiente das células fixas.

A formação do EPS ainda não é bem conhecida, porém há correntes que afirmam que superfícies sólidas estimulam a produção do polímero para que as células se agreguem. WRANGSTAH, et al. (1989) mostraram que a presença de superfície sólida acelera o aparecimento de células ligadas ao exopolímero durante o estágio inicial de fome das

\footnotetext{
${ }^{3}$ Geesy, G.G.,(1982). Microbgial Exopolymers: Ecological and Economic considerations. ASM News, 48: 9-14.
} 
Pseudomonas sp. Segundo SPEECE (1996), há um sinergismo entre os microrganismos alocados em forma de grânulos ou aderidos em suportes. Essa agregação peculiar otimiza a cooperação entre os organismos constituintes do biofilme devido à redução da distância para a transferência de produtos metabólicos. Porém, ALLISON \& SUTHERLAND (1987) demonstraram que duas espécies de bactérias de água doce somente sintetizaram quantidades significativas de EPS depois da aderência, indicando que o polímero não foi necessário para adesão inicial em superfícies inertes.

O EPS pode estar envolvido na formação do biofilme requerido para a adesão e sobrevivência da bactéria Xantomona fastidiosa em ambientes hidrodinamicamente turbulentos, que é o caso das veias do xilema da planta (PETRY, et al., 2000).

Como a estrutura de biofilmes é muito complexa e envolve muitos micro-ambientes é possível que exista heterogeneidade entre diferentes subpopulações de algumas espécies de bactérias. Algumas podem produzir exopolímeros simples, enquanto outras, em diferentes partes do mesmo biofilme, podem formar diferentes polímeros ou mais que um polissacarídeo que podem exercer diferentes funções (SUTHERLAND, 2001).

A estrutura e a composição do EPS dependem de vários fatores, como por exemplo, a espécie microbiana, a natureza do substrato e condições de fermentação (MARGARITS \& PACE, 1985).

A quantidade de substrato convertida em polímero pelas células depende da composição do meio. Geralmente, um meio que contém uma alta carga de carbono, limitando a razão de nutrientes, muitas vezes o nitrogênio, favorece a formação do EPS (WILDINSON, $1958^{4}$; SUTHERLAND, 19795; apud MARGARITS \& PACE, 1985).

Estudos contínuos sobre o efeito do substrato limitante do crescimento, na síntese de exopolixacarídeos, por vários tipos diferentes de microrganismos, demonstraram claramente que a composição do meio pode afetar drasticamente a síntese do polímero. Alguns exemplos do efeito da composição do meio no rendimento de polímeros de células livres são apresentados na Tabela 3.1 (MARGARITIS \& PACE,1985).

Estudos realizados por PETRY et al. (2000), em meio específico contendo inicialmente glicose como fonte de carbono, alterando para ácido orótico em culturas de Lactobacillus delbreckii subsp. Bulgaricus sugerem que as unidades das estruturas do polissacarídeo podem variar de acordo com alterações específicas do meio.

\footnotetext{
${ }^{4}$ Wilkinson, J. F. (1958). The extracellular polyssaccharides of bacteria. Bacteriological Reviews 22 (1): 46-73.

${ }^{5}$ Sutherland, I. W. (1979). Microbial exopolysaccharides: control of synthesis and acylation. In Microbial Polysaccharides and Polysaccharases, ed. R. C. W, Berkeley, G. W. Gooday and D. C. Ellwood. Academic, London.
} 
A influência das condições da cultura na produção de EPS pelos Bacillus licheniformis estudada por LARPIN, et al. (2002) mostrou que o aumento da concentração de açúcar no meio, não aumentou a produção do EPS, porém, quando o meio foi suplementado com etanol, houve aumento da produção do polímero.

Segundo VEIGA, et al. (1997), a temperatura, os substratos e a concentração de nutrientes chaves (nitrogênio $\mathrm{e}$ fosfato) afetaram a produção do EPS pelas Methanobacterium formicicum.

MOZZI et al. (2001) estudaram o efeito da glicose e da galactose na produção do EPS pelos Lactobacillus casei CRL 87. Esses autores observaram que a fonte de carbono presente no meio de cultura afeta a produção do polímero. Uma maior produção de polímero foi observada em meios de culturas contendo galactose como fonte de carbono.

Tabela 3.1. Efeito de nutrientes limitantes de crescimento no rendimento da produção de EPS

\begin{tabular}{|c|c|c|c|}
\hline Microrganismo & Polímero & Nutriente Limitante & Rendimento $^{I}$ \\
\hline \multirow[t]{6}{*}{ X. campestris* } & Xantana & Glicose & 0.54 \\
\hline & & $\mathrm{NH}_{4}{ }^{+}$ & 0.60 \\
\hline & & $\mathrm{SO}_{4}^{-}$ & 0.53 \\
\hline & & $\mathrm{Mg}^{++}$ & 0.55 \\
\hline & & $\mathbf{K}^{+}$ & 0.42 \\
\hline & & $\mathrm{PO}_{4}{ }^{3-}$ & 0.31 \\
\hline \multirow[t]{3}{*}{ Os. Aerugenosa $* *$} & Alginato & Glicose & 0.33 \\
\hline & & $\begin{array}{l}\mathbf{N} \text { (extrato de } \\
\text { levedura) }\end{array}$ & 0.61 \\
\hline & & $\mathbf{N H}_{4}^{+}$ & $\mathbf{0 . 5 3}$ \\
\hline
\end{tabular}

* Davidson, (1978) $)^{6}$ apud Margaritis \& Pace, 1985

** Mian et al., (1978) ${ }^{7}$ apud Margaritis \& Pace, 1985

${ }^{1}$ Cada conjunto de resultados se refere a experimentos conduzidos em uma razão de diluição constante, e os valores representam a quantidade de polímero produzido por células livres por unidade de glicose consumida.

Em culturas de Aeromonas salmonicida A450 não houve a produção de EPS quando em ausência de glicose, fosfato, cloreto de magnésio ou componentes de metais traços. Foi observada que a formação do EPS independe da relação $\mathrm{C} / \mathrm{N}$, embora fosse esperado o contrário (BONET, et al. 1993).

QUAGLIANO (1999) estudou a biossíntese de polihidroxibutirato (PHB) e EPS em Azotobacter chroococcum utilizando fontes de carbono simples e complexa. Observou que

\footnotetext{
${ }^{6}$ Davidson, I. W. (1968). Production of polysaccharide by Xanthomonas compestris in continuous culture. FEMS Microbiol. Lett. 3,347-349.

${ }^{7}$ Mian, F. A., Jarman, T. R.,Righelato, R. C. (1978). Biosynthesis of exopolysaccharide by Pseudomonas aeruginosa. J. Bacteriol., 134: 418-422.
} 
em meio contendo sulfato de amônio houve redução da produção de PHB e EPS em substratos com glicose, sacarose e frutose. Em substratos como melaço de cana de açúcar, glicose e frutose foi observada a síntese de grandes quantidades de EPS.

No trabalho de TAKEI et al. (1995), a produção de EPS em culturas líquidas de Polianthes tuberosa aumentou com a adição de sais minerais e, quando o meio foi suplementado com cloreto de cálcio, a produção do EPS foi maior do que sem esse sal.

Como visto, todos os trabalhos citados foram estudos realizados com culturas puras de células. No entanto, não se sabe se em um consórcio microbiano o processo e as causas de produção de EPS são os mesmos. 


\section{MATERIAL E MÉTODOs}

\subsection{Material}

\subsubsection{Configuração do Reator em Batelada}

O reator anaeróbio em batelada seqüencial contendo células imobilizadas, proposto por RATUZNEI et al. (2000) e modificado por CUBAS et al. (2001)., apresentado na Figura 4.1, era constituído por um frasco de vidro cilíndrico de $22 \mathrm{~cm}$ de diâmetro e $26 \mathrm{~cm}$ de altura, com capacidade total de cinco litros. Agitação foi suprida por um agitador mecânico com 2 impelidores tipo turbina de $3 \mathrm{~cm}$ de diâmetro com 4 pás planas, distanciados $8 \mathrm{~cm}$ um do outro. A alimentação e descarga eram realizadas por bombas tipo diafragma marca Prominente, modelo $\alpha$. Para manter a temperatura, o reator era encamisado com uma estrutura de vidro, por onde escoava água aquecida em banho ultratermostatizado Marconi, modelo BTC-9090. As biopartículas foram confinadas em um cesto de aço Inox 316, perfurado, com um cilindro central de $4 \mathrm{~cm}$ de diâmetro, onde foi introduzida a barra de agitação. $\mathrm{O}$ cesto possui diâmetro interno de $4 \mathrm{~cm}$, diâmetro externo de $22 \mathrm{~cm}$ e altura de 18 $\mathrm{cm}$. 


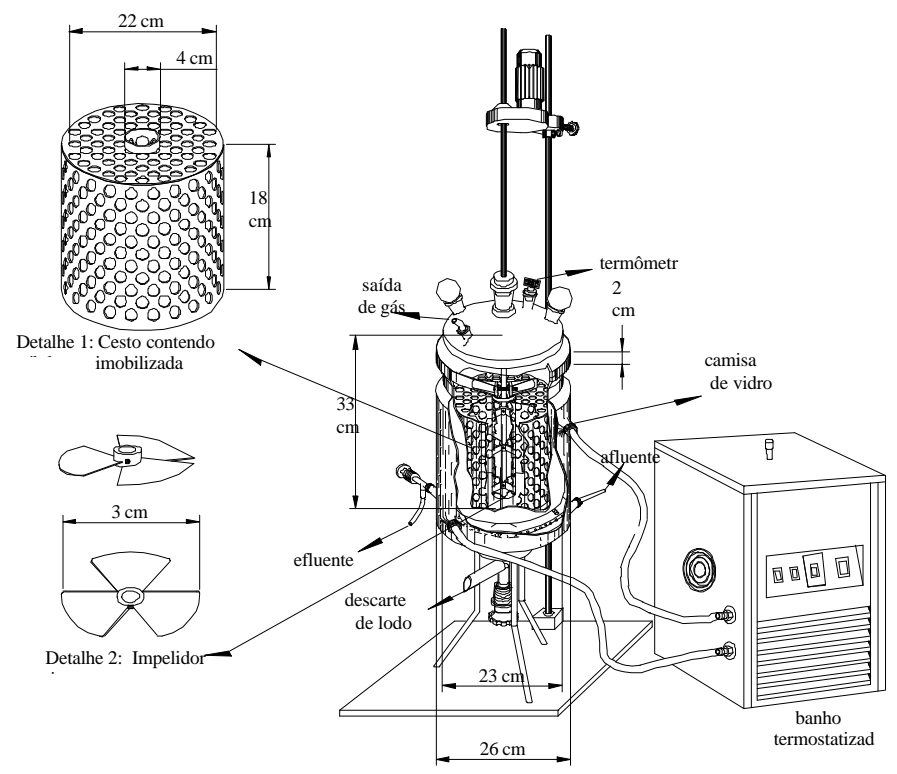

Figura 4.1. Esquema do Reator Anaeróbio Seqüencial em Batelada utilizados nesse trabalho.

\subsubsection{Suporte de Imobilização da Biomassa Anaeróbia}

Como suporte de imobilização da biomassa foi utilizado espuma de poliuretano, com densidade aparente de $23 \mathrm{~kg} / \mathrm{m}^{3}$, porosidade próxima a $95 \%$ e isenta de corantes e aditivos (Edmil Indústria e Comércio - Elói Mendes, MG). A espuma foi utilizada na forma de cubos de $1 \mathrm{~cm}$ de aresta.

\subsubsection{Inóculo}

$\mathrm{O}$ inóculo utilizado foi proveniente de reator anaeróbio de manta de lodo $\mathrm{e}$ escoamento ascendente (UASB), tratando água residuária de abatedouro de aves.

\subsection{4. Água Residuária Sintética}

O biorreator foi alimentado com substrato sintético, contendo glicose como principal fonte de carbono, preparado de acordo com DEL NERY (1987) e mantido em geladeira para manutenção das características ao longo da operação. A composição da água residuária sintética está apresentada na Tabela 4.1. 
Tabela 4.1. Composição de água residuária sintética utilizada*

\begin{tabular}{lr}
\hline \multicolumn{1}{c}{ Composto } & Concentração (mg/L) \\
\hline Glicose & 1000,0 \\
Uréia & 62,5 \\
Sulfato de níquel & 0,5 \\
Sulfato ferroso & 2,5 \\
Cloreto férrico & 0,25 \\
Cloreto de cálcio & 23,5 \\
Cloreto de cobalto & 0,04 \\
Óxido de selênio & 0,035 \\
Fosfato de potássio monobásico & 42,5 \\
Fosfato de potássio dibásico & 10,85 \\
Fosfato de sódio dibásico & 16,7 \\
Bicarbonato de sódio & 1000,0
\end{tabular}

Fonte: Del Nery (1987)

*A concentração de glicose foi variada de $500 \mathrm{mg} / \mathrm{L}$ a $2000 \mathrm{mg} / \mathrm{L}$, bem como as concentrações de sais proporcionalmente.

Os valores apresentados na Tabela 4.1 são baseados em concentração de glicose de $1000 \mathrm{mg} / \mathrm{L}$, e demanda química de oxigênio também da ordem de $1000 \mathrm{mg} / \mathrm{L}$. Vale ressaltar que a água residuária foi preparada com as concentrações de glicose variando de 500 a 2000 $\mathrm{mg} / \mathrm{L}$, sendo os demais compostos adicionados proporcionalmente.

\subsection{Métodos}

\subsubsection{Determinação da Concentração de Glicose}

A concentração de glicose foi medida por método espectrofotométrico utilizando o kit Glicose, método enzimático da Laborlab, desenvolvido para determinação de glicose no sangue. A glicose reage com a enzima glicose oxidase, dando uma coloração rosa detectada no comprimento de onda $505 \mathrm{~nm}$. Foram adicionados $20 \mu \mathrm{L}$ de amostra para $3 \mathrm{~mL}$ de reagente. Para determinação da concentração de glicose na amostra foi feita curva padrão de absorbância em função da concentração. 


\subsection{2. Ácidos Voláteis Totais por Cromatografia Gasosa}

As amostras coletadas do afluente e efluente para análise de ácidos eram filtradas, alcalinizadas com uma solução de $\mathrm{NaOH}$ em excesso e em seguida congeladas, para posteriormente serem analisadas

As análises dos ácidos voláteis foram feitas segundo MORAES et al. (2000) por cromatografia gasosa, utilizando cromatógrafo HP 6890, com detector de ionização de chama, coluna HP INNOWAX $30 \mathrm{~m}$ x 0,25 mm x 0,25 $\mu \mathrm{m}$ de espessura de filme. O gás de arraste foi $\mathrm{H}_{2}$ com fluxo de $2,0 \mathrm{~mL} / \mathrm{min}$., temperatura do injetor igual a $250^{\circ} \mathrm{C}$, split de 20 , volume de injeção de $1,0 \mu \mathrm{L}$. A temperatura do forno foi igual a $100^{\circ} \mathrm{C}$ durante 3 minutos, rampa de aquecimento $5^{\circ} \mathrm{C} / \mathrm{min}$., até $180^{\circ} \mathrm{C}$, durante 5 minutos. "Postrun" de $200^{\circ} \mathrm{C}$ durante 3 minutos. A temperatura do detector foi de $300^{\circ} \mathrm{C}$, com fluxos de ar sintético de $300 \mathrm{~mL} / \mathrm{min}$, fluxo de $\mathrm{N}_{2}$ (make up) $35 \mathrm{~mL} /$ min.e fluxo de $\mathrm{H}_{2}$ igual a $30 \mathrm{~mL} / \mathrm{min}$.

Antes de fazer as análises dos ácidos, eram obtidas as curvas de calibração para cada ácido por regressão linear simples:

$y=m \cdot x+b$

Nessa expressão: y é a razão entre as áreas cromatográficas do ácido e do padrão interno, $x$ é a concentração do ácido, m é a inclinação (coeficiente angular) e b é a interseção (coeficiente linear).

A partir das curvas foram determinados os valores do limite de detecção (LD), que é a concentração mínima de cada ácido que o cromatógrafo pode detectar. O limite de detecção foi calculado de acordo com a expressão 4.2.

$L D=\frac{\left(3 . S E_{b}+b\right)}{m}$

Nessa expressão: $\mathrm{SE}_{\mathrm{b}}$ é o erro padrão do intercepto (MILLER \& MILLER, 1984).

\subsubsection{Análise DQO, Sólidos, Ácidos Voláteis Totais e Alcalinidade a Bicarbonato}

Análises de demanda química de oxigênio (DQO) de amostras brutas e filtradas e série de sólidos foram realizadas segundo o Standard Methods for the Examination of Water and Wastewater (1998). Alcalinidade total, bicarbonato e ácidos voláteis totais foram 
analisados titulometria utilizando método se DILALLO \& ALBERTSON (1961), modificado por RIPLEY et al. (1986).

\subsubsection{Exames Microbiológicos}

Os exames microbiológicos do lodo anaeróbio foram realizados por microscopia ótica utilizando-se microscópio Olympus modelo BX 60-FLA, com sistema de câmara colorida digital Optronics. O software usado para aquisição das imagens foi o Image ProPlus versão 3.0.1. Através desse equipamento foi possível captar as imagens e registrar os tipos morfológicos presentes nas amostras.

Todas as amostras foram examinadas em lâminas de vidro cobertas com filme de ágar a $2 \%$.

\subsubsection{Coloração Gram}

Foi utilizado o método modificado de Hücker (JENKINS et al., 1993 \& WEF, 1995) para exame de coloração Gram.

Nesta metodologia foram usadas três soluções:

- Solução 1: é a mistura da Solução A com a Solução B.

Foram preparadas Solução A, composta de $2 \mathrm{~g}$ de violeta cristral em $20 \mathrm{~mL}$ de etanol 95\% e Solução B, composta de $0,8 \mathrm{~g}$ de oxalato de amônio em $80 \mathrm{~mL}$ de água destilada.

- Solução 2 (solução de lugol) é composta de $1 \mathrm{~g}$ de iodo e $2 \mathrm{~g}$ de iodeto de potássio em $300 \mathrm{~mL}$ de água destilada.

- $\underline{\text { Solução } 3}$ é composta de $10 \mathrm{~mL}$ de safrina (2,5\% peso/volume em etanol 95\%) em $10 \mathrm{~mL}$ de água destilada.

Procedimento:

a) Coloca-se uma gota da amostra na lâmina e esperar secar

b) A lâmina é coberta com a Solução 2 por 1 minuto e em seguida lavada rapidamente com água

c) Então a lâmina é coberta com a Solução 1 por 1 minuto e lavada muito bem com água

d) Para descobrir a amostra adiciona-se etanol $95 \%$ gota a gota durante 25 segundos. Este procedimento foi realizado até eliminar o excesso de violeta cristal 
e) A lâmina é coberta com a Solução 3 por 1 minuto, lavada muito bem com água e seca com papel

f) A lâmina é então examinada em óleo de imersão em aumento de 1000 vezes com iluminação direta

Resultado:

Coloração azul-violeta significa que o microrganismo é Gram-positivo e Gramnegativo quando a coloração é vermelha.

\subsubsection{Composição dos Gases}

A composição dos gases gerados pela degradação anaeróbia foi monitorada por cromatografia gasosa utilizando-se cromatógrafo Gow-Mac com detector de condutividade térmica e coluna "Porapak Q" (2m x 1/4’ - 80 a 100 mesh). O gás de arraste foi o hidrogênio a $1 \mathrm{~mL} / \mathrm{s}$.

\subsubsection{Potencial Redox}

A medida do potencial redox foi feita com o aparelho Digimed modelo DM-21. Foi utilizado o eletrodo combinado de platina Pt4805 da Mettler-Toledo. O eletrodo foi colocado no topo do reator e o contato com o efluente ocorreu na superfície do líquido. 


\section{PROCEDIMENTO EXPERIMENTAL}

A parte experimental foi realizada em duas etapas. A primeira etapa teve como objetivo principal testar a eficiência do ASBBR, contendo biomassa imobilizada em espuma de poliuretano, quando submetido ao aumento progressivo da concentração do substrato. Nessa etapa, operou-se o reator com ciclos de 8 horas e com concentração de glicose variando de 500 a $2000 \mathrm{mg} / \mathrm{L}$, aproximadamente.

Como foi verificada a formação de grande quantidade de uma massa viscosa, similar a polímero extracelular ou exopolissacarídeo (EPS) na primeira etapa, decidiu-se, então, pela realização de uma segunda etapa desse projeto, operando-se o reator com tempo de ciclo de 3 horas.

O objetivo principal da segunda etapa foi verificar se a diminuição do tempo de ciclo interferiria na formação do EPS. O longo tempo de ciclo da primeira etapa poderia estar submetendo os microrganismos a longos períodos de privação de alimento e desviando o metabolismo para formação de EPS como material de reserva. O tempo de 3 horas foi definido depois da análise dos perfis temporais de glicose e DQO quando o reator foi operado com $500 \mathrm{mg} / \mathrm{L}$ e $1000 \mathrm{mg} / \mathrm{L}$ de glicose em ciclos de 8 horas.

\subsection{Operação do ASBR com 8 horas de Ciclo - $1^{\text {a }}$ Etapa}

\subsubsection{Imobilização da Biomassa Anaeróbia}

O lodo anaeróbio foi imobilizado em partículas cúbicas de espuma de poliuretano, conforme metodologia proposta por ZAIAT et al. (1994). Quarenta e cinco (45) gramas de espuma de poliuretano seca foram colocadas em um recipiente e, aproximadamente 3,5 L de lodo foram adicionados até que toda a espuma estivesse em contato com a suspensão. Esse contato ocorreu por 24 horas. Decorrido esse período, as matrizes com as células aderidas foram colocadas no cesto e este dentro do reator. A lavagem dos sólidos fracamente aderidos foi feita durante os primeiros 15 ciclos com o substrato utilizado. 


\subsubsection{Amostragem}

Amostras do afluente e efluente foram coletadas três vezes por semana para as análises: DQO de amostras brutas e filtradas, glicose, AVT por cromatografia $\left(\mathrm{AVT}_{\mathrm{c}}\right)$ e por titulometria $\left(\mathrm{AVT}_{\mathrm{t}}\right), \mathrm{pH}$ e alcalinidade a bicarbonato. $\mathrm{O}$ afluente foi coletado no final da mangueira de alimentação no ponto conectado ao reator e o efluente, no final da mangueira de descarte.

Para análises microbiológicas e de sólidos, foram retiradas amostras de espumas da superfície, do centro e do fundo do cesto. O número total de espumas retiradas ao final de cada operação era em torno de 12 cubos.

Para as análises microbiológicas dos expolissacarídeos foram retiradas pequenas quantidades de amostras da superfície da tampa do cesto e das partes superior e inferior da barra de agitação.

\subsubsection{Operação do ASBBR com Aumento Progressivo da Concentração de Glicose} no Afluente

$\mathrm{O}$ reator foi operado à temperatura constante de $30^{\circ} \mathrm{C} \pm 1{ }^{\circ} \mathrm{C}$ com concentrações crescentes de glicose, variando de 500 a $2000 \mathrm{mg} / \mathrm{L}$. Inicialmente, o reator foi operado com concentração afluente de $500 \mathrm{mg} \mathrm{DQO} / \mathrm{L}$, sendo aumentada ao longo do tempo para 1000 mg/L e 2000 mg DQO/L. As mudanças das concentrações na alimentação foram realizadas após ser atingida estabilidade operacional, ou seja, após constatar-se que não tinha havido variação da DQO do efluente entre dois ciclos consecutivos.

O reator foi operado em ciclos de 8 horas, ou seja, três bateladas seqüenciais por dia. No início de um ciclo de operação, o reator foi alimentado com volume aproximado de 4,2 litros de água residuária sintética, durante $10 \mathrm{~min}$. A fase de reação foi de $459 \mathrm{~min}$., com a agitação fixa a $300 \mathrm{rpm}$, baseado em ensaios previamente realizados por CUBAS et al. (2001). Ao término do ciclo, o efluente era descarregado durante $10 \mathrm{~min}$.

Após o descarte do efluente, foi estabelecido um intervalo de tempo de 1 min como segurança no sincronismo de operação das duas bombas usadas na alimentação e descarga, controladas por temporizadores, para então, o próximo ciclo ser reiniciado.

$\mathrm{O}$ reator foi monitorado ao longo da primeira batelada do dia. Antes da alimentação da primeira batelada, era coletada amostra do afluente para as análises da concentração de glicose, da demanda química de oxigênio (DQO), alcalinidade parcial (AP), alcalinidade intermediária (AI), alcalinidade total (AT), alcalinidade a bicarbonato (AB), ácidos voláteis totais $\left(\mathrm{AVT}_{\mathrm{c}}\right.$ e $\left.\mathrm{AVT}_{\mathrm{t}}\right)$ e pH. Logo após a alimentação, a saída de gases era fechada para que 
se efetuasse a análise da composição dos gases por cromatografia, 15 minutos antes do início do descarte. Durante o descarte, $200 \mathrm{~mL}$ de efluente eram coletados para realizar as mesmas análises que foram feitas no afluente. As análises de sólidos totais (ST), sólidos totais voláteis (STV), sólidos suspensos totais (SST) e sólidos suspensos voláteis (SSV) foram realizadas eventualmente para avaliação de arraste de biomassa do sistema. Os parâmetros foram monitorados com frequiência de três vezes por semana.

Antes de ser alimentado, o substrato armazenado em geladeira, a aproximadamente $4^{\circ} \mathrm{C}$, era bombeado através de serpentina alocada em banho de água aquecida, possibilitando que a água residuária entrasse no reator à temperatura de $30^{\circ} \mathrm{C} \pm 1^{\circ} \mathrm{C}$, evitando choque térmico no sistema.

Depois de atingida a estabilidade operacional, foram realizados perfis temporais de alguns parâmetros de monitoramento ao longo de uma batelada. Durante as 8 horas da batelada eram colhidas amostras para análise de DQO, glicose, pH, alcalinidade, ácidos totais e ácidos voláteis por cromatografia. Foram realizados também perfis temporais de concentrações de metano no biogás e de potencial redox. Os perfis possibilitaram a melhor compreensão das rotas de degradação ao longo de um ciclo, além de permitirem a obtenção de parâmetros cinéticos de degradação da matéria orgânica.

As amostras para obtenção do perfil temporal de DQO, glicose e ácidos voláteis foram coletadas em intervalos de tempos de 15 minutos, na primeira hora de operação, passando para intervalos de 30 minutos, nas próximas 4,5 horas e, em seguida, para intervalos de tempo de uma hora, nas últimas coletas. O volume de amostra coletada, em cada amostragem, foi de $20 \mathrm{~mL}$, representando, no final do ensaio, volume total menor de $10 \%$ do volume do reator. Os perfis de $\mathrm{pH}$, alcalinidade e ácidos totais foram realizados no dia seguinte. $\mathrm{O}$ volume coletado para cada amostragem foi de $30 \mathrm{~mL}$ e os intervalos de tempo das coletas foram de 15 minutos, na primeira hora de operação, passando para intervalos de 30 minutos, nas próximas 1,5 horas, após 1 hora foi coletada outra amostra e a última, após 2 horas. Esses intervalos foram definidos de acordo com os resultados obtidos com os perfis temporais de DQO e glicose.

O modelo cinético de primeira ordem foi ajustado aos perfis temporais de glicose e o modelo de primeira ordem modificado (eq. 3.1) foi ajustado aos perfis temporais de DQO.

Após obtenção dos perfis temporais, as condições operacionais eram mudadas, ou seja, aumentava-se a concentração afluente, iniciando-se nova fase de operação.

Ao final de cada experimento, foram coletadas amostras de biopartículas em espuma de poliuretano e de polímeros. Além da análise microbiológica das biopartículas foi realizada também análise de sólidos. 


\subsection{Operação do ASBR com 3 horas de Ciclo - $2^{\mathrm{a}}$ Etapa}

O reator foi reinoculado utilizando o mesmo procedimento da primeira etapa.

Todo o procedimento experimental foi realizado de maneira a reproduzir todas as condições da primeira etapa. Os tempos de alimentação e descarte foram de 10 minutos e a fase de reação foi de 160 minutos, com 8 bateladas (ciclos) sequienciais por dia. O reator foi operado com $500 \mathrm{mg} / \mathrm{L}$ e $1000 \mathrm{mg} / \mathrm{L}$ de glicose, mas foi possível a realização dos perfis temporais somente para a condição com $500 \mathrm{mg} / \mathrm{L}$ de glicose.

Os parâmetros monitorados nesta etapa foram os mesmo da primeira etapa. Os perfis temporais foram realizados depois do reator ter sido operado com os mesmos números de ciclos de cada condição na primeira etapa. Nos perfis temporais de glicose, DQO filtrada e ácidos voláteis, determinados por cromatografia $\left(\mathrm{AVT}_{\mathrm{C}}\right)$, foram coletadas $20 \mathrm{~mL}$ de amostras a cada 15 minutos durante todo o ciclo. Nos perfis de alcalinidade a bicarbonato e ácidos voláteis totais, determinados por titulometria $\left(\mathrm{AVT}_{\mathrm{t}}\right)$, foram coletadas $30 \mathrm{~mL}$ de amostra a cada 15 minutos durante uma hora, e depois passando para 30 minutos. Gases e potencial redox foram examinados a cada 15 minutos durante todo o ciclo.

Realizou-se o estudo cinético utilizando a equação 5.1 para glicose e DQO.

Ao final de cada experimento, amostras de biopartículas de espuma de poliuretano e amostras de polímeros que foram produzidos durante a operação foram retiradas do reator para análise microbiológica. Além da análise microbiológica das biopartículas foi realizada também análise de sólidos. Nessa etapa, o EPS foi quantificado, fazendo-se a raspagem de todo o material que estava no reator e no cesto de inox, determinando-se a concentração de sólidos.

\subsection{Resumo das Condições Experimentais}

Na Tabela 5.1 são apresentadas as principais condições operacionais de cada etapa dos experimentos realizados a $30^{\circ} \mathrm{C} \pm 1^{\circ} \mathrm{C}$.

A carga orgânica volumétrica (COV) foi calculada pela seguinte expressão:

$$
\operatorname{COV}=\frac{\mathrm{V}_{\mathrm{alim}} \cdot \mathrm{C}_{\mathrm{g}}}{\mathrm{V}_{\mathrm{R}}}
$$

Nessa expressão, $\mathrm{C}_{\mathrm{g}}$ é a concentração de glicose afluente, $\mathrm{V}_{\text {alim }}$ é o volume de água residuária alimentado diariamente $\mathrm{e} \mathrm{V}_{\mathrm{R}}$ é o volume útil total do reator. Na primeira etapa, 
12,6 litros de água residuária foram tratadas por dia (4,2 litros por ciclo), enquanto que, na etapa 2, o volume tratado diariamente aumentou para 33,6 litros. $\mathrm{O}$ volume útil do reator foi de 5,0 litros.

Tabela 5.1. Resumo das condições operacionais nas duas etapas experimentais.

\begin{tabular}{cccc}
\hline Etapa & $\begin{array}{c}\text { Tempo de ciclo } \\
\text { (h) }\end{array}$ & $\begin{array}{c}\text { Concentração de } \\
\text { glicose afluente* } \\
(\mathrm{mg} / \mathrm{L})\end{array}$ & $\begin{array}{c}\text { Carga orgânica } \\
\text { volumétrica - COV } \\
(\mathrm{mg} / \mathrm{L} . \mathrm{dia})\end{array}$ \\
\hline 1 & 8 & 470 & 1184,4 \\
& & 852 & 2147,0 \\
& & 1943 & 4896,4 \\
\hline 2 & 3 & 495 & 3326,4 \\
& 990 & 6652,8
\end{tabular}

* Valores médios observados durante os experimentos 


\section{RESULTADOS E DISCUSSÕES}

\subsection{Operação do ASBBR com 8 horas de Ciclo - $1^{\text {a }}$ Etapa}

Nessa etapa, o reator foi operado com ciclos de 8 horas. As concentrações de glicose no afluente variaram de $500 \mathrm{mg} / \mathrm{L}$ a $2000 \mathrm{mg} / \mathrm{L}$, aproximadamente.

\subsubsection{Operação com aproximadamente $500 \mathrm{mg} / \mathrm{L}$ de glicose}

Os valores médios de DQO total $\left(\mathrm{DQO}_{\mathrm{t}}\right)$, DQO filtrada $\left(\mathrm{DQO}_{\mathrm{f}}\right)$, concentrações de glicose $\left(\mathrm{C}_{\mathrm{g}}\right)$, alcalinidade a bicarbonato $(\mathrm{AB})$, ácidos voláteis totais obtidos por cromatografia $\left(\mathrm{AVT}_{\mathrm{C}}\right)$, ácidos voláteis totais obtidos por titulometria $\left(\mathrm{AVT}_{\mathrm{t}}\right)$, cujos valores são dados em miligrama de ácido acético por litro (mg HAc/L) e pH no afluente e efluente durante o período de operação com a concentração de glicose em torno de $500 \mathrm{mg} / \mathrm{L}$ estão apresentados na Tabela 6.1.

Tabela 6.1: Médias de DQO, concentrações de glicose, alcalinidade a bicarbonato e ácidos totais $\left(\mathrm{AVT}_{\mathrm{c}}\right.$ e $\mathrm{AVT}_{\mathrm{t}}$ ) de entrada e saída do ASBBR durante o período de operação com 470 $\pm 37 \mathrm{mg} / \mathrm{L}$ de glicose.

\begin{tabular}{lccccccc}
\hline & $\begin{array}{c}\mathbf{D Q O}_{\mathbf{t}} \\
(\mathbf{m g} / \mathbf{L})\end{array}$ & $\begin{array}{c}\mathbf{D Q O}_{\mathbf{f}} \\
(\mathbf{m g} / \mathbf{L})\end{array}$ & $\begin{array}{c}\mathbf{C g} \\
(\mathbf{m g} / \mathbf{L})\end{array}$ & $\begin{array}{c}\mathbf{A B} \\
\left(\mathbf{m g C a C O}_{\mathbf{3}} / \mathbf{L}\right)\end{array}$ & $\begin{array}{c}\mathbf{A V T}_{\mathbf{c}} \\
(\mathbf{m g} / \mathbf{L})\end{array}$ & $\begin{array}{c}\mathbf{A V T}_{\mathbf{t}} \\
(\mathbf{m g H A c} / \mathbf{L})\end{array}$ & $\mathbf{p H}$ \\
\hline Valor Médio no & $550 \pm 29$ & $541 \pm 27$ & $470 \pm 37$ & $294 \pm 8$ & $11,6 \pm 1,6$ & $20,5 \pm 5,5$ & $7,6 \pm 0,4$ \\
Afluente & $(10)$ & $(10)$ & $(10)$ & $(10)$ & $(4)$ & $(10)$ & $(10)$ \\
Valor Médio no & $45 \pm 19$ & $25 \pm 8$ & & $321 \pm 9$ & $16,4 \pm 0,2$ & $20,5 \pm 5,4$ & $6,8 \pm 0,2$ \\
Efluente & $(10)$ & $(10)$ & 0 & $(10)$ & $(4)$ & $(10)$ & $(10)$ \\
\hline
\end{tabular}

( ) número de amostragens. 
De acordo com a Tabela 6.1, os valores de $\mathrm{DQO}_{\mathrm{t}} \mathrm{e} \mathrm{DQO}_{\mathrm{f}}$ no afluente estão muito próximos devido ao substrato ser composto basicamente de glicose, substância muito solúvel em meio aquoso. A partir dessa observação, foram adotados valores afluentes de $\mathrm{DQO}_{\mathrm{f}}$ para apresentação nos gráficos.

Os valores médios dos parâmetros e os desvios indicam que a operação do reator transcorreu de forma equilibrada e sem maiores problemas quando alimentado com água residuária com concentração de glicose de $470 \pm 37 \mathrm{mg} / \mathrm{L}$. Não foi detectada glicose no efluente, mesmo em amostras obtidas no início da operação e o efluente apresentou baixos valores de DQO.

As amostras do efluente apresentaram maior alcalinidade a bicarbonato quando comparadas às amostras afluentes indicando estabilidade do processo anaeróbio de degradação da matéria orgânica.

A concentração de $\mathrm{AVT}_{\mathrm{c}}$ no efluente foi levemente maior que do afluente, o que não se observa nos resultados obtidos por titulometria, nos quais não existem diferenças entre as concentrações do efluente e do afluente. Maior erro pode estar associado às médias das concentrações obtidas por método cromatográfico devido ao pequeno número de amostragens. De qualquer forma, as concentrações de AVT no afluente e efluente foram muito baixas. $\mathrm{O} \mathrm{pH}$ do efluente ficou em torno de 6,8 , embora a alcalinidade a bicarbonato tenha apresentado aumento no efluente, como efeito da pressão parcial de $\mathrm{CO}_{2}$ na atmosfera do reator.

As variações dos parâmetros, durante operação do ASBBR operando com ciclo de 8 horas e com concentração de glicose no afluente de $470 \pm 37 \mathrm{mg} / \mathrm{L}$, podem ser observadas nas Figuras 6.1 a 6.8 . 


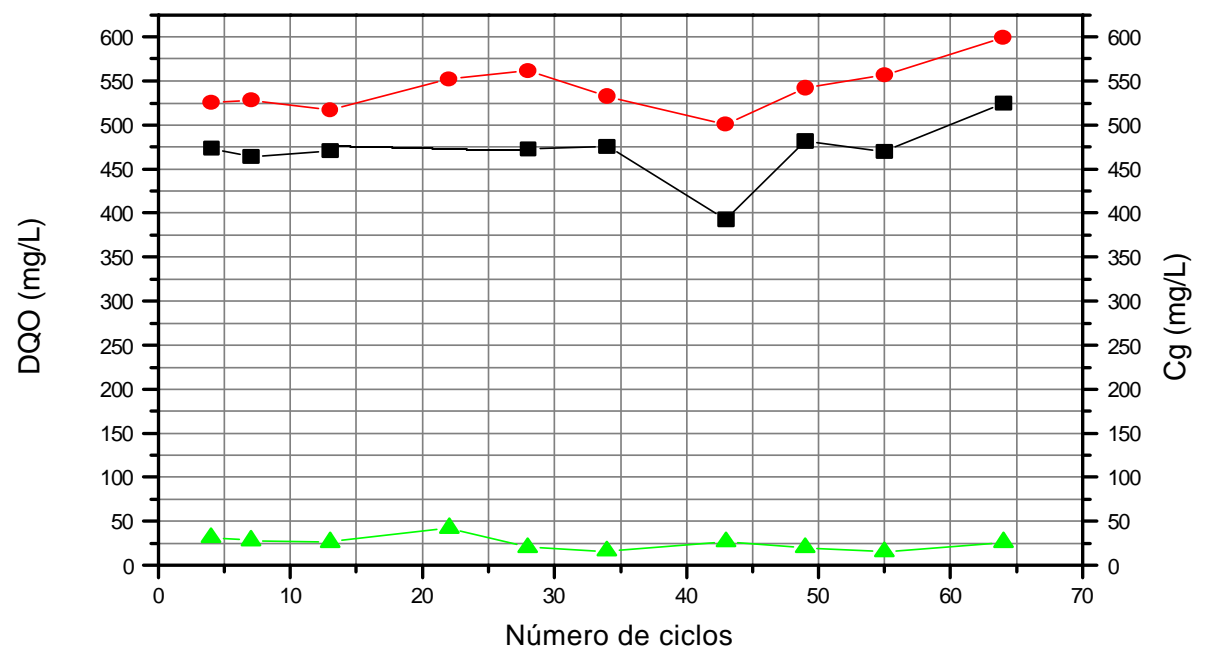

Figura 6.1: Valores de concentração de glicose afluente (•) e de DQO filtrada do afluente $(\bullet)$ e efluente $(\stackrel{\bullet}{*})$ durante o período de operação do ASBBR alimentado com $470 \pm$ $37 \mathrm{mg} / \mathrm{L}$ de glicose e 8 horas de ciclo.

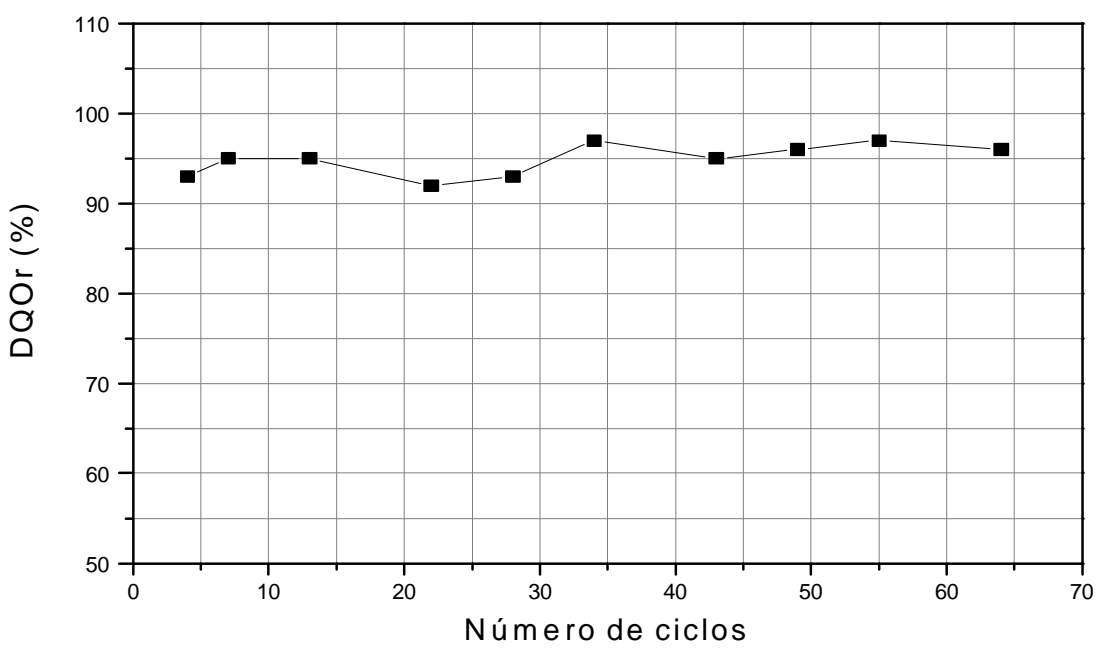

Figura 6.2: Eficiência de remoção de DQO filtrada (-) durante o período de operação do ASBBR alimentado com $470 \pm 37 \mathrm{mg} / \mathrm{L}$ de glicose e 8 horas de ciclo. 


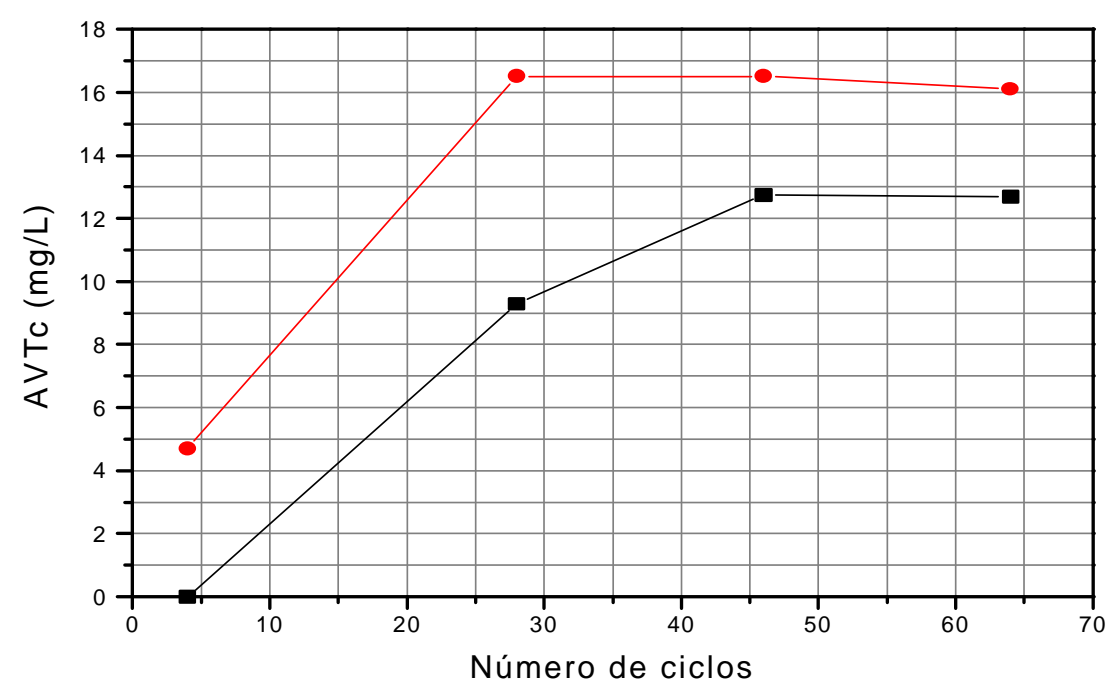

Figura 6.3: Valores da concentração de ácidos voláteis totais, obtidos por cromatografia, do afluente $(\bullet)$ e do efluente $(\bullet)$ durante o período de operação do ASBBR alimentado com $470 \pm 37 \mathrm{mg} / \mathrm{L}$ de glicose e 8 horas de ciclo.

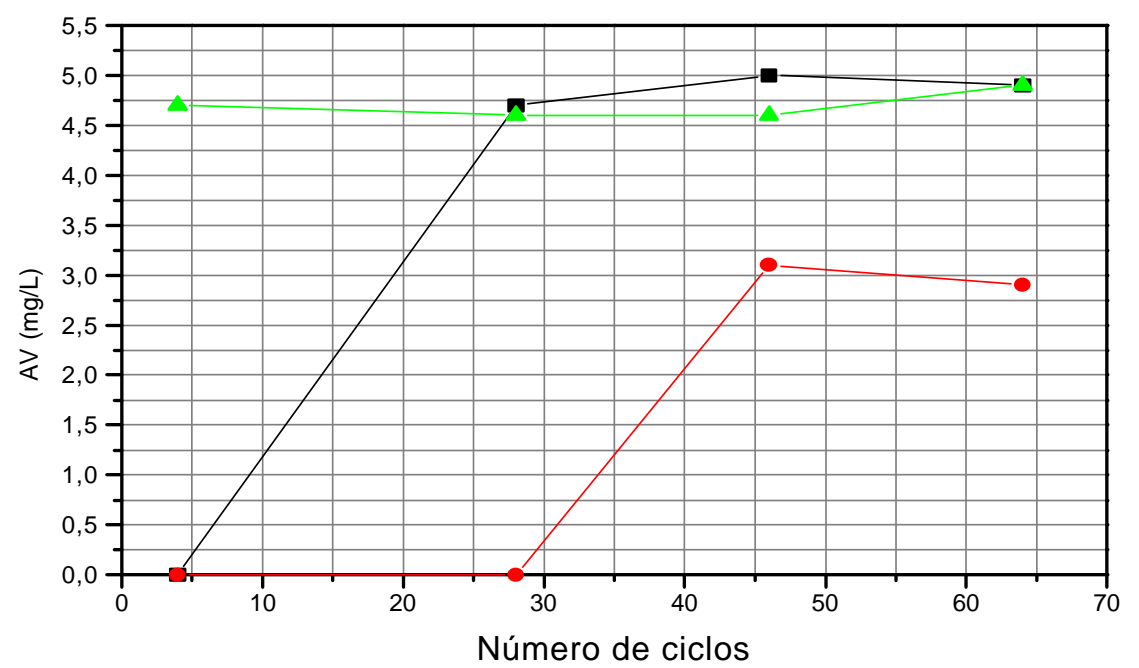

Figura 6.4: Valores das concentrações dos ácidos propiônico (•), butírico (^) e isobutírico $(\bullet)$ no afluente, obtidos durante o período de operação do ASBBR alimentado com $470 \pm 37 \mathrm{mg} / \mathrm{L}$ de glicose e 8 horas de ciclo. 


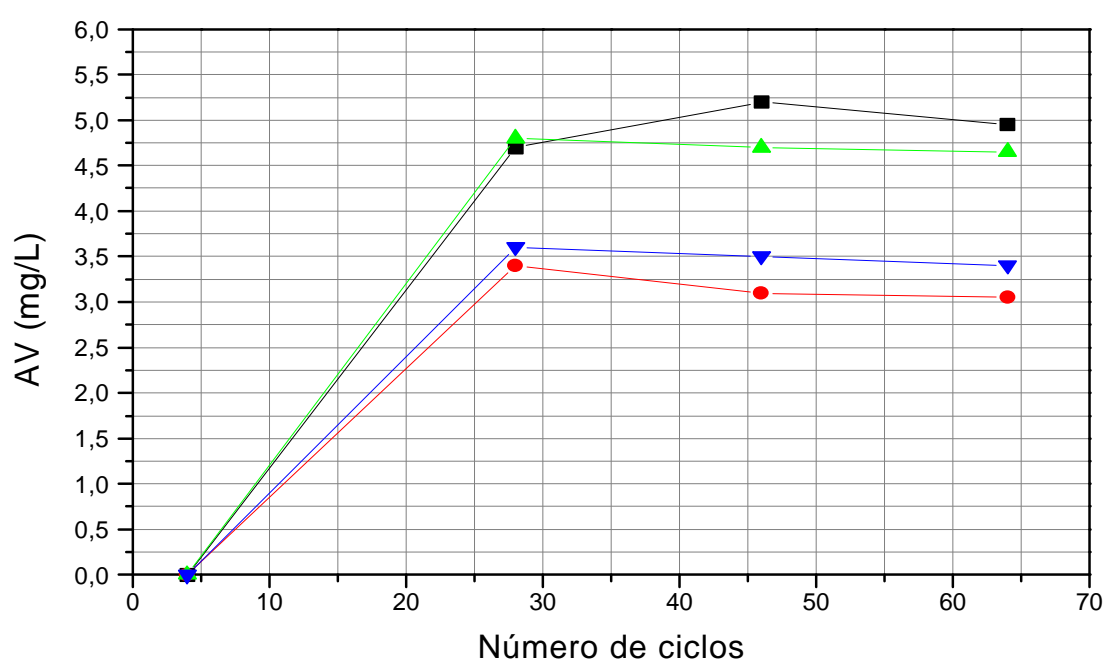

Figura 6.5: Valores das concentrações dos ácidos propiônico (•), butírico ( $\left.{ }^{\star}\right)$, isovalérico $\left({ }^{\vee}\right)$ e isobutírico $(\bullet)$ no efluente, obtidos durante o período de operação do ASBBR alimentado com $470 \pm 37 \mathrm{mg} / \mathrm{L}$ de glicose e 8 horas de ciclo.

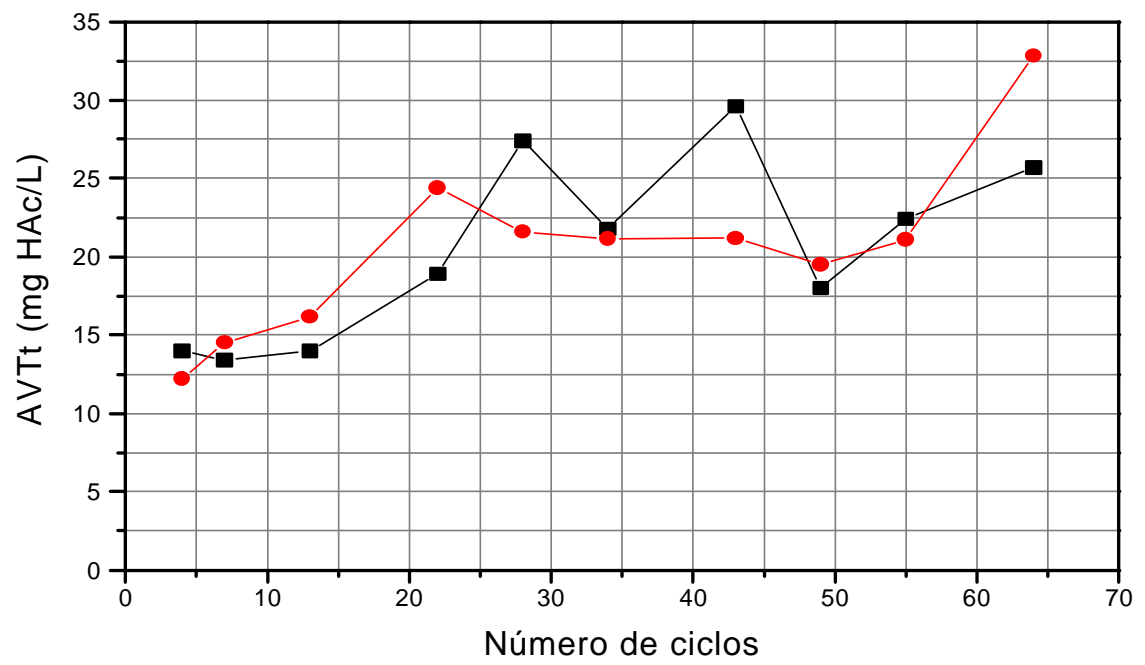

Figura 6.6: Valores da concentração de ácidos totais, obtidos por titulometria, do afluente $(\bullet)$ e do efluente $(\bullet)$ durante o período de operação do ASBBR alimentado com 470 $\pm 37 \mathrm{mg} / \mathrm{L}$ de glicose e 8 horas de ciclo. 


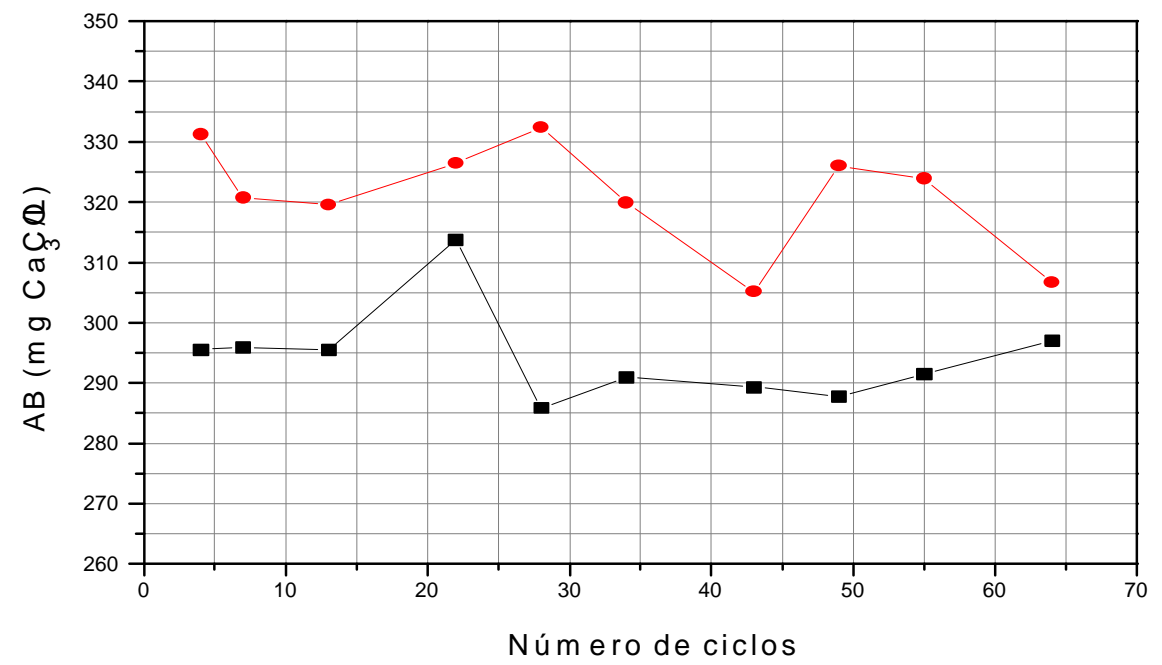

Figura 6.7: Alcalinidade a bicarbonato do afluente $(\bullet)$ e do efluente $(\bullet)$ durante o período de operação do ASBBR alimentado com $470 \pm 37 \mathrm{mg} / \mathrm{L}$ de glicose e 8 horas de ciclo.

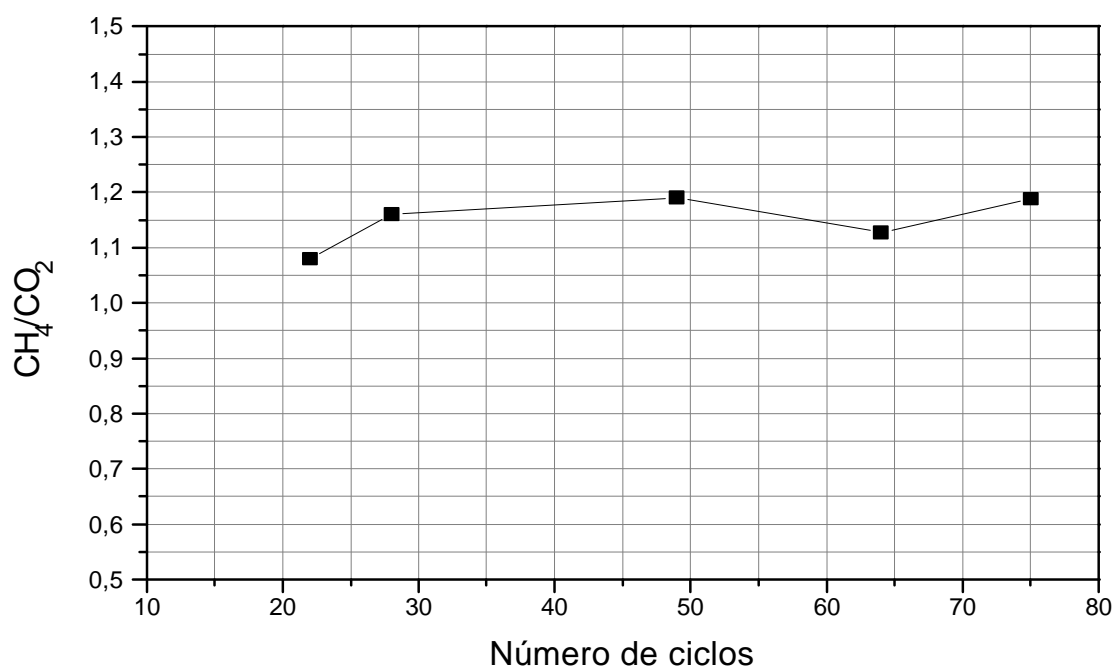

Figura 6.8: Relação da composição molar entre os gases $\mathrm{CH}_{4}$ e $\mathrm{CO}_{2}$ durante o período de operação do ASBBR alimentado com $470 \pm 37 \mathrm{mg} / \mathrm{L}$ de glicose e 8 horas de ciclo.

Nas Figuras 6.1 e 6.2 pode-se observar que a remoção da DQO foi praticamente constante com a eficiência variando entre $92 \%$ e $97 \%$ durante todo o período de operação.

As concentrações de ácidos voláteis no afluente e no efluente, determinadas por cromatografia gasosa (Figura 6.3), foram muito próximas. Foi observado um leve aumento 
nas concentrações entre o ciclo 4 e 28, mantendo-se constante em seguida numa concentração de aproximadamente $13 \mathrm{mg} / \mathrm{L}$ para o afluente e $16 \mathrm{mg} / \mathrm{L}$ para o efluente.

Os ácidos presentes no afluente (Figura 6.4) foram propiônico, butírico, e isobutírico, porém observou-se a presença do butírico somente a partir do ciclo 40. No efluente, observou-se a presença dos ácidos propiônico, butírico, isovalérico e isobutírico (Figura 6.5). A presença de ácidos graxos no afluente, em baixas concentrações indica uma ligeira pré-acidificação do meio no recipiente de alimentação.

Acompanhando-se o monitoramento de AVT por titulometria (Figura 6.6), observase que as concentrações de ácidos no afluente e no efluente são aproximadamente iguais, com exceção dos ciclos 28 e 43 em que as concentrações dos ácidos no afluente estão maiores que no efluente, provavelmente devidos a erros experimentais. Pode-se observar, também, que as concentrações dos ácidos, obtidas por titulometria, estão relativamente próximas às concentrações obtidas por cromatografia. Contudo, pode-se constatar que a determinação de ácidos voláteis por titulometria nos indica o valor aproximado das concentrações dos ácidos no meio e que ambos os métodos podem indicar qual é a condição de estabilidade do processo, porém o titulométrico não especifica os ácidos, mas pode ser realizado mais rapidamente. Portando, somente os valores das concentrações de ácidos voláteis, obtidos por cromatografia, serão apresentados nas próximas condições experimentais.

As alcalinidades a bicarbonato do afluente e do efluente mantiveram-se praticamente constantes ao longo dos dias (Figura 6.7). Os valores de alcalinidade a bicarbonato no efluente foram sempre superiores aos observados no afluente, indicando estabilidade do processo anaeróbio de conversão da matéria orgânica durante toda a operação.

Nas análises de gases por cromatografia gasosa (Figura 6.8), a relação molar entre $\mathrm{CH}_{4}$ e $\mathrm{CO}_{2}$ ficou entre aproximadamente 1,05 e 1,20. Portanto, a concentração molar do $\mathrm{CH}_{4}$ alcança um valor de 5 a $20 \%$ maior que $\mathrm{CO}_{2}$. Nesse caso, a porcentagem mínima de metano em relação ao dióxido de carbono no biogás foi de 51,2\% e a máxima de 54,5\%.

Após 20 dias de operação, com o reator estável, ou seja, quando os valores de DQO do efluente não apontaram variação de um dia para outro, foram feitas as análises do perfil temporal de $\mathrm{DQO}_{\mathrm{f}}, \mathrm{AVT}_{\mathrm{c}}, \mathrm{AVT}_{\mathrm{t}}$, alcalinidade a bicarbonato, composição de gases e potencial redox.

Os resultados obtidos dos perfis temporais podem ser observados nas Figuras 6.9 a 6.12 . 


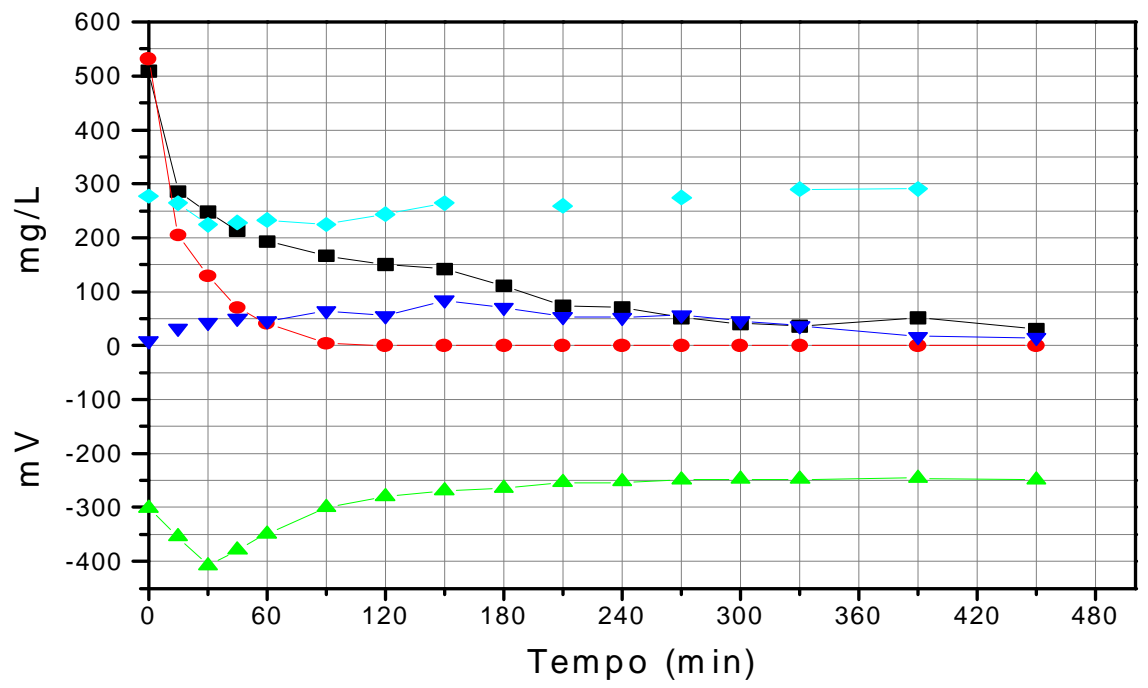

Figura 6.9: Perfil temporal de DQO (•), concentração de glicose $(\bullet)$, AVT pelo método cromatográfico $\left({ }^{\vee}\right)$, alcalinidade a bicarbonato $(\diamond)$ e potencial redox $(\stackrel{\bullet}{)}$ do ASBBR alimentado com $470 \pm 37 \mathrm{mg} / \mathrm{L}$ de glicose e 8 horas de ciclo.

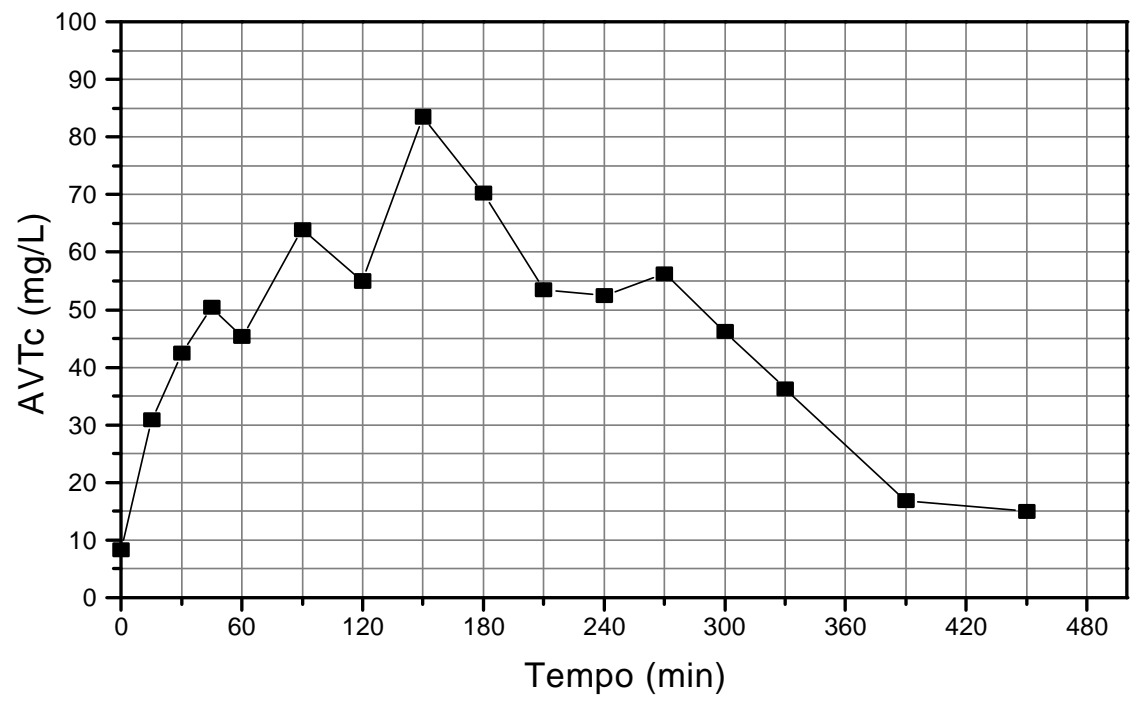

Figura 6.10: Concentrações de AVT, determinado por cromatografia, durante o perfil temporal do ASBBR alimentado com $470 \pm 37 \mathrm{mg} / \mathrm{L}$ de glicose e 8 horas de ciclo. 


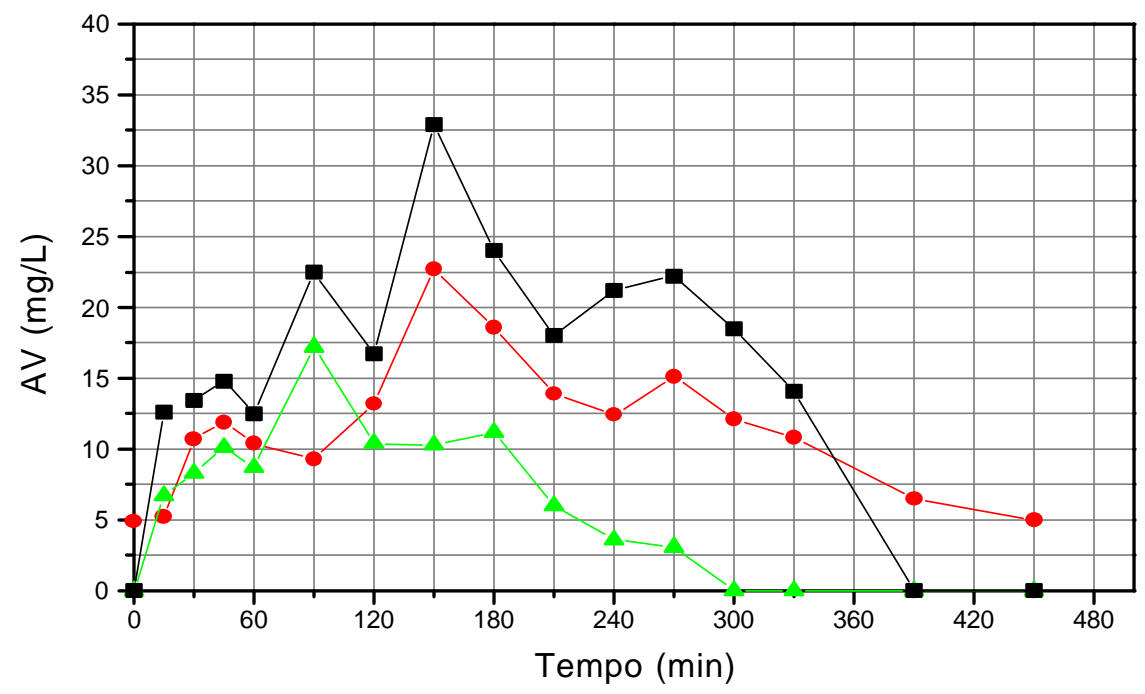

Figura 6.11: Concentrações dos ácidos acético $(\bullet)$, propiônico $(\bullet)$ e butírico $\left({ }^{\bullet}\right)$ durante o perfil temporal do ASBBR alimentado com $470 \pm 37 \mathrm{mg} / \mathrm{L}$ de glicose e 8 horas de ciclo.

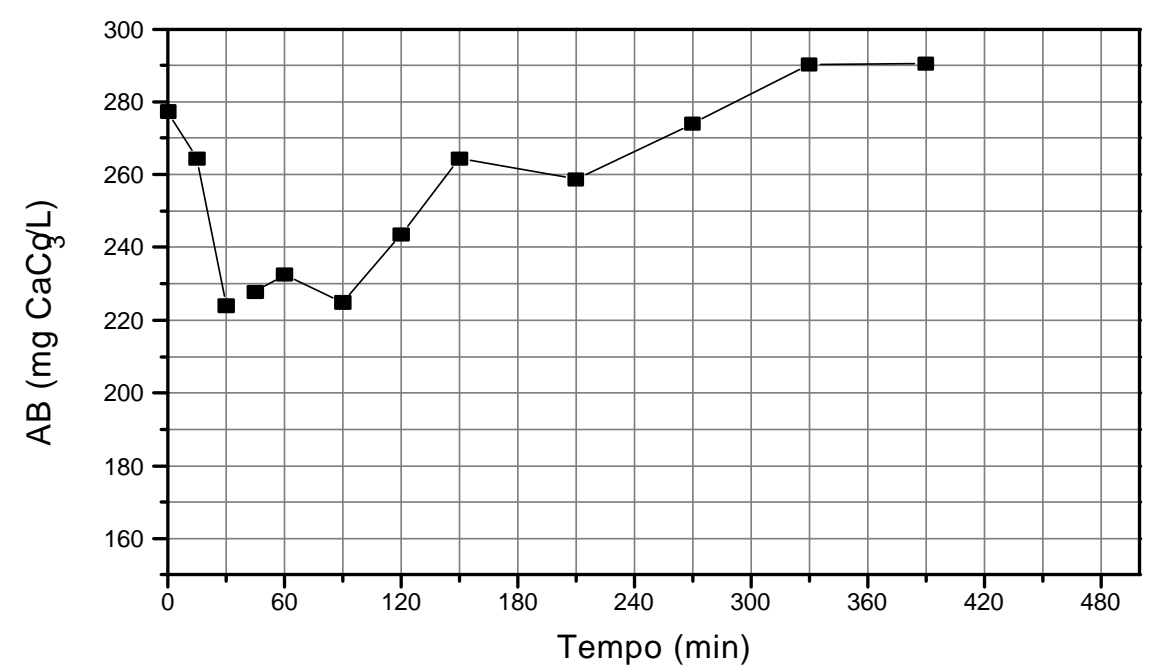

Figura 6.12: Valores da alcalinidade a bicarbonato determinado durante o perfil temporal do ASBBR alimentado com $470 \pm 37 \mathrm{mg} / \mathrm{L}$ de glicose e 8 horas de ciclo. 


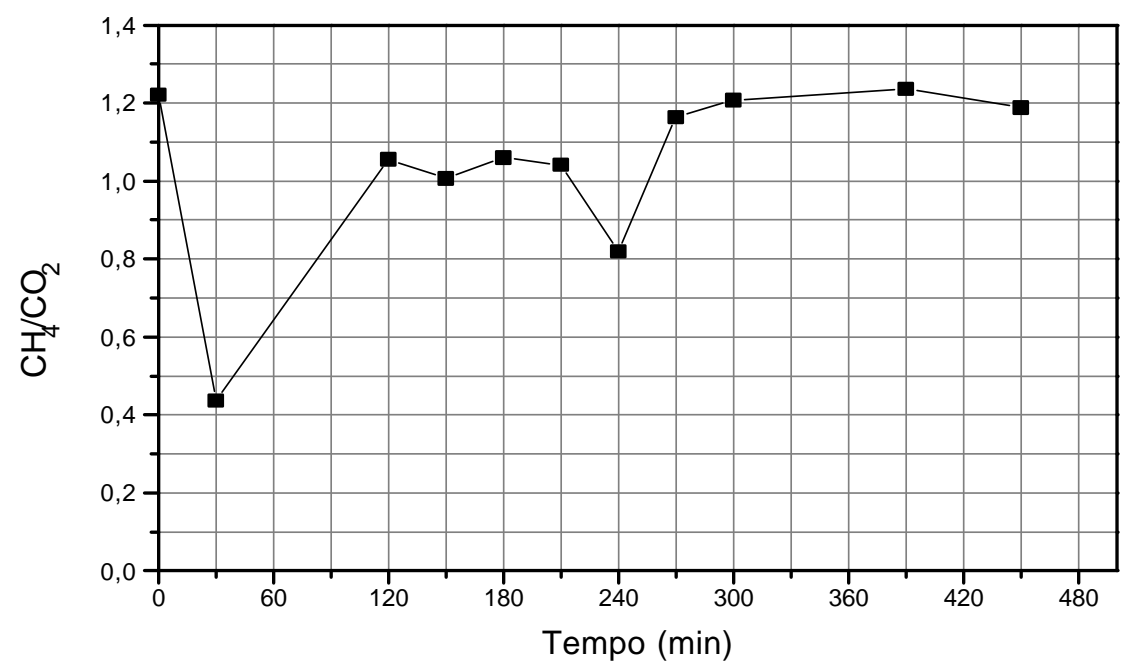

Figura 6.13: Perfil temporal da composição de gases, representado como a relação de $\mathrm{CH}_{4}$ e $\mathrm{CO}_{2}$, no ASBBR alimentado com $470 \pm 37 \mathrm{mg} / \mathrm{L}$ de glicose e 8 horas de ciclo.

No decorrer do ciclo (Figura 6.9), pode-se observar que a glicose é totalmente degradada nos primeiros 90 minutos de batelada. Assim que começa a degradação da glicose ocorre a produção de ácidos. Após 180 minutos, a curva de decaimento da DQO acompanha a de produção de ácidos. Entre 90 e 180 minutos pode estar ocorrendo a formação de outros intermediários, tais como ácido láctico, ácido formico e alguns álcoois, não analisados.

Os ácidos presentes em maior quantidade até os 330 minutos de operação são propiônico, acético e butírico (Figura 6.11). Após 330 minutos, as concentrações dos ácidos decaem, restando os ácidos propiônico $(5,5 \mathrm{mg} / \mathrm{L})$, isobutírico $(3,0 \mathrm{mg} / \mathrm{L})$, isovalérico $(3,4$ $\mathrm{mg} / \mathrm{L})$ e capróico $(3,5 \mathrm{mg} / \mathrm{L})$.

Foi observado ocorrer decaimento na alcalinidade a bicarbonato (Figura 6.12), de 280 para aproximadamente $230 \mathrm{mg} \mathrm{CaCO} / / \mathrm{L}$, nos primeiros 90 minutos de operação. Neste mesmo período houve aumento de $55 \mathrm{mg} / \mathrm{L}$ de ácidos (Figura 6.11). Logo após ter início a degradação do acido butírico a alcalinidade a bicarbonato aumentou, atingindo em torno de $290 \mathrm{mg} \mathrm{CaCO} / 3$. O consumo da alcalinidade pode ser confirmado observando-se a Figura 6.13, que indica o perfil da relação molar entre $\mathrm{CH}_{4}$ e $\mathrm{CO}_{2}$. Nesse período, constata-se ter ocorrido maior produção de $\mathrm{CO}_{2}$.

$\mathrm{O}$ potencial redox variou de $-300 \mathrm{a}-400 \mathrm{mV}$ nos primeiros 30 minutos, mantendose praticamente constante em $-270 \mathrm{mV}$ após 100 minutos de operação.

Em experimentos realizados por BRITO et al. (1997), tratando substrato composto por $10 \%$ de glicose e $90 \%$ de uma mistura de ácido acético, propiônico e butírico na proporção 2:1:1, o potencial redox do sistema foi reduzido a $-400 \mathrm{mV}$ em 30 minutos de 
operação. Segundo HARPER \& POLAND (1986), valores obtidos abaixo de $-370 \mathrm{mV}$ indicam que o oxigênio foi completamente removido do sistema, eventualmente com a contribuição de bactérias facultativas.

O sistema foi operado com ciclo de 8 horas e concentração afluente de glicose de $470 \pm 37 \mathrm{mg} / \mathrm{L}$ sem maiores problemas. O processo anaeróbio permaneceu equilibrado durante os 64 ciclos de operação, atingindo alta eficiência de remoção de matéria orgânica. Após esse período de operação, observou-se uma pequena quantidade de uma massa viscosa, possivelmente polímero extracelular (EPS), na superfície do cesto e na haste de agitação.

\subsubsection{Operação com aproximadamente $1000 \mathrm{mg} / \mathrm{L}$ de glicose}

Os valores médios de DQO total $\left(\mathrm{DQO}_{\mathrm{t}}\right)$, DQO filtrada $\left(\mathrm{DQO}_{\mathrm{f}}\right)$, concentrações de glicose $\left(\mathrm{C}_{\mathrm{g}}\right)$, alcalinidade a bicarbonato $(\mathrm{AB})$, ácidos voláteis totais, determinados por cromatografia $\left(\mathrm{AVT}_{\mathrm{c}}\right)$ e por titulometria $\left(\mathrm{AVT}_{\mathrm{t}}\right)$, e $\mathrm{pH}$ no afluente e efluente durante o período de operação com aproximadamente $1000 \mathrm{mg} / \mathrm{L}$ de glicose estão apresentados na Tabela 6.2.

Tabela 6.2: Médias de DQO, concentrações de glicose, alcalinidade a bicarbonato e ácidos totais $\left(\mathrm{AVT}_{\mathrm{c}}\right.$ e $\left.\mathrm{AVT}_{\mathrm{t}}\right)$ de entrada e saída do ASBBR durante o período de operação com $852 \pm 190 \mathrm{mg} / \mathrm{L}$ de glicose.

\begin{tabular}{lccccccc}
\hline & $\begin{array}{c}\mathbf{D Q O}_{\mathbf{t}} \\
(\mathbf{m g} / \mathbf{L})\end{array}$ & $\begin{array}{c}\mathbf{D Q O}_{\mathbf{f}} \\
(\mathbf{m g} / \mathbf{L})\end{array}$ & $\begin{array}{c}\mathbf{C g} \\
(\mathbf{m g} / \mathbf{L})\end{array}$ & $\begin{array}{c}\mathbf{A B} \\
\left(\mathbf{m g C a C O}_{\mathbf{3}} / \mathbf{L}\right)\end{array}$ & $\begin{array}{c}\mathbf{A V T}_{\mathbf{c}} \\
(\mathbf{m g} / \mathbf{L})\end{array}$ & $\begin{array}{c}\mathbf{A V T}_{\mathbf{t}} \\
(\mathbf{m g H A c} / \mathbf{L})\end{array}$ & $\mathbf{p H}$ \\
\hline Valor Médio no & $985 \pm 118$ & $973 \pm 117$ & $852 \pm 190$ & $479 \pm 78$ & $29,2 \pm 23,1$ & $65,2 \pm 40,9$ & $7,36 \pm 0,40$ \\
Afluente & $(24)$ & $(27)$ & $(27)$ & $(27)$ & $(9)$ & $(24)$ & $(27)$ \\
Valor Médio no & $182 \pm 75$ & $147 \pm 88$ & & $509 \pm 89$ & $159 \pm 72$ & $88,0 \pm 59,5$ & $6,72 \pm 0,27$ \\
Efluente & $(24)$ & $(27)$ & 0 & $(27)$ & $(9)$ & $(24)$ & $(27)$ \\
\hline
\end{tabular}

( ) número de amostragens.

$\mathrm{Na}$ Tabela 6.2 pode-se observar pouca diferença entre a $\mathrm{DQO}_{\mathrm{t}}$ e $\mathrm{DQO}_{\mathrm{f}}$ tanto no afluente como do efluente. A pequena variação no efluente indica que não houve arraste significativo de sólidos nessa condição operacional.

Nessa fase de operação, o sistema também apresentou boa remoção de matéria orgânica, com concentração efluente de glicose sempre não detectada. A alcalinidade a bicarbonato foi gerada no sistema, indicando equilíbrio das etapas de conversão anaeróbia da matéria orgânica. No entanto, as concentrações de ácidos voláteis no efluente foram 
superiores às observadas no afluente, indicando alguma possível instabilidade, a qual pode ser mais bem visualizada nas Figuras 6.14 a 6.21, as quais apresentam os valores dos parâmetros obtidos durante a operação do reator.

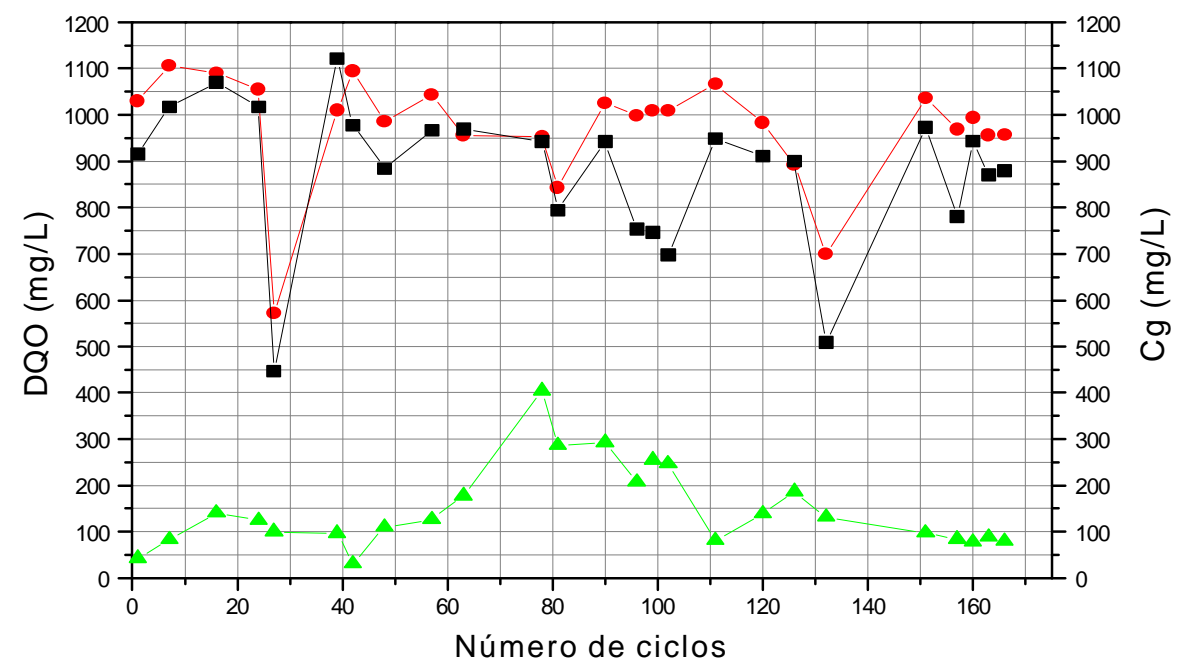

Figura 6.14: Valores de concentração de glicose afluente (•) e DQO filtrada do afluente $(\bullet)$ e efluente $(\stackrel{\bullet}{)}$ ) durante o período de operação do ASBBR alimentado com $852 \pm$ $190 \mathrm{mg} / \mathrm{L}$ de glicose e 8 horas de ciclo.

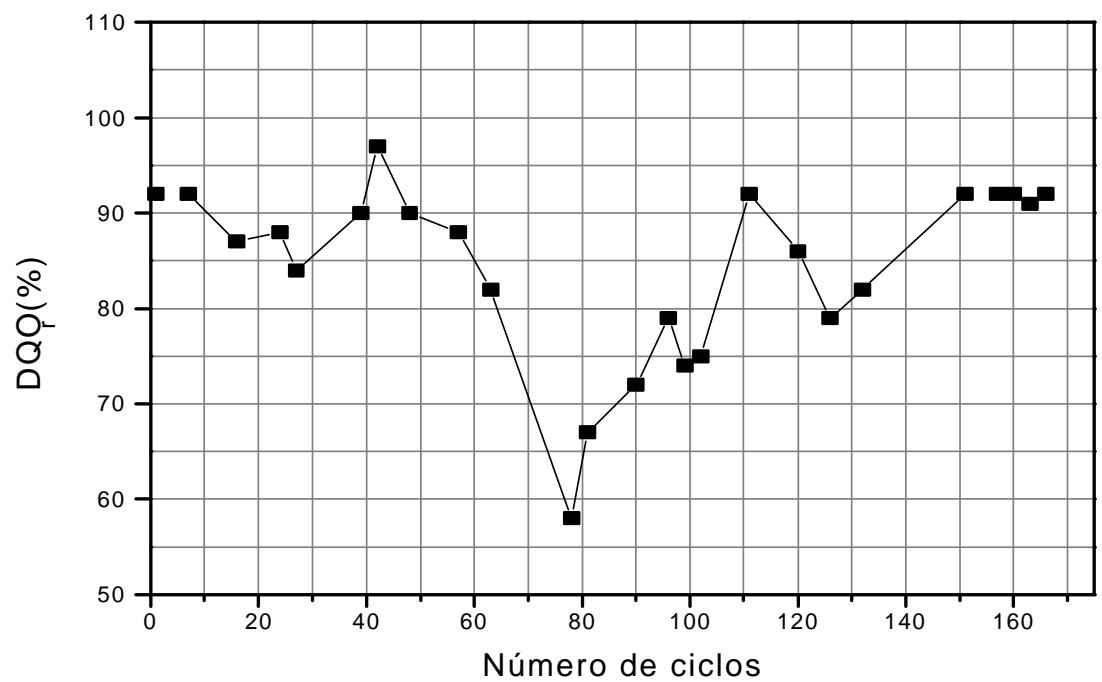

Figura 6.15: Eficiência de redução da DQO (•) durante o período de operação do ASBBR alimentado com $852 \pm 190 \mathrm{mg} / \mathrm{L}$ de glicose e 8 horas de ciclo. 


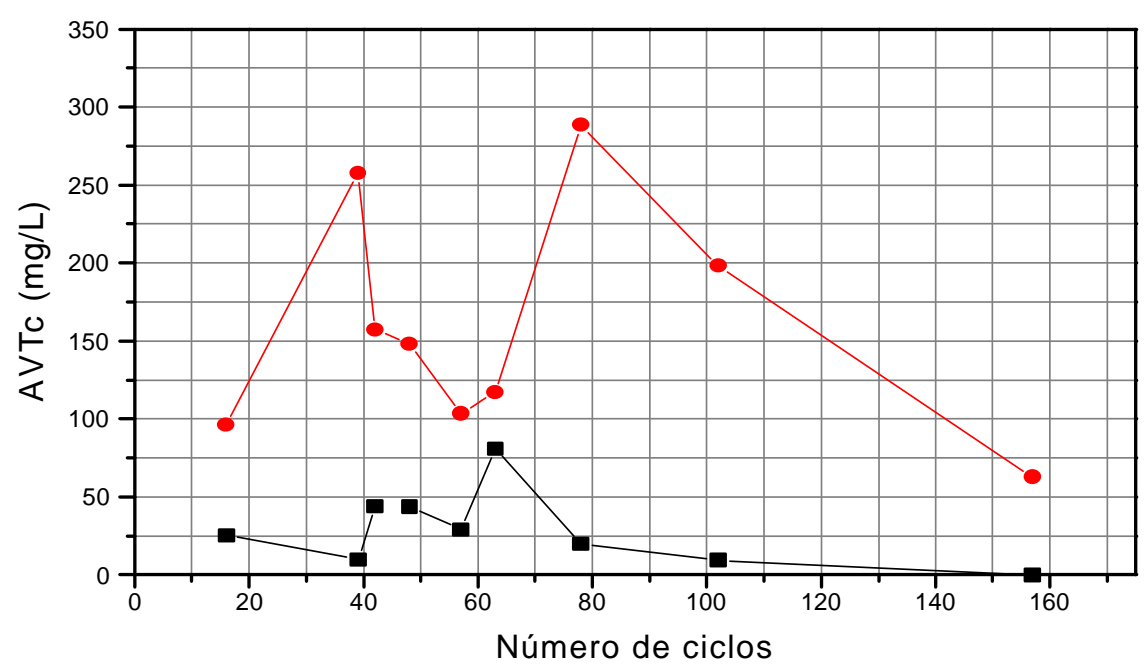

Figura 6.16: Análise da produção de ácidos voláteis totais, obtidos por cromatografia, do afluente $(\bullet)$ e efluente $(\bullet)$ durante o período de operação do ASBBR alimentado com $852 \pm 190 \mathrm{mg} / \mathrm{L}$ de glicose e 8 horas de ciclo.

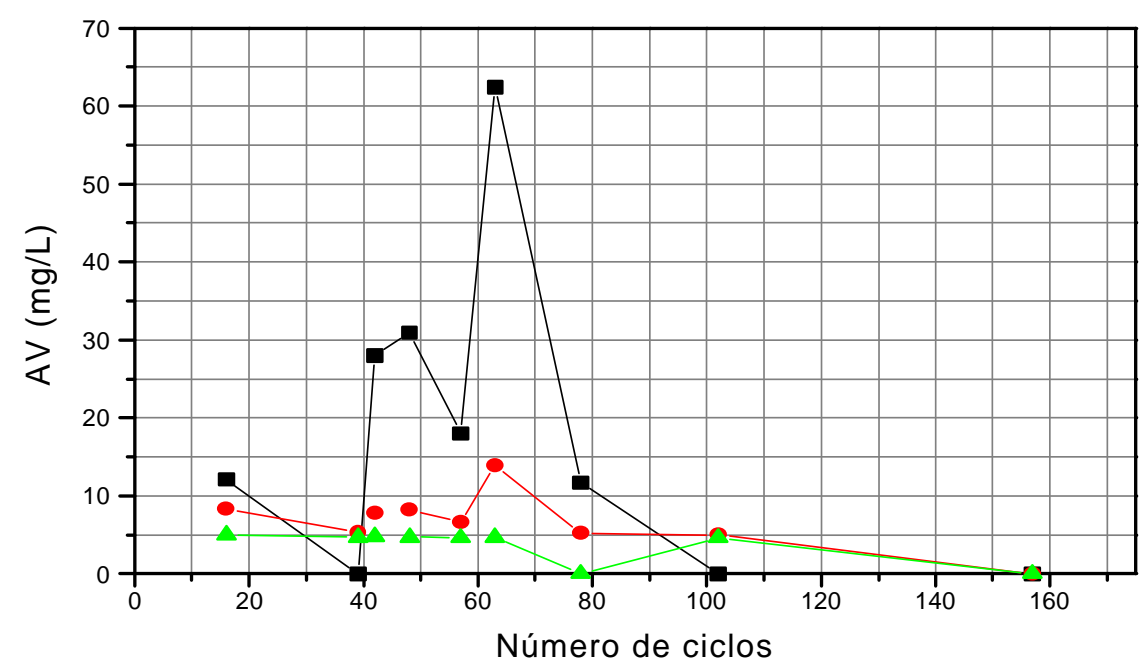

Figura 6.17: Valores da concentração dos ácidos acético (•), propiônico (•) e butírico $\left({ }^{\star}\right)$ obtidos por cromatografia, do afluente durante o período de operação do ASBBR alimentado com $852 \pm 190 \mathrm{mg} / \mathrm{L}$ de glicose e 8 horas de ciclo. 


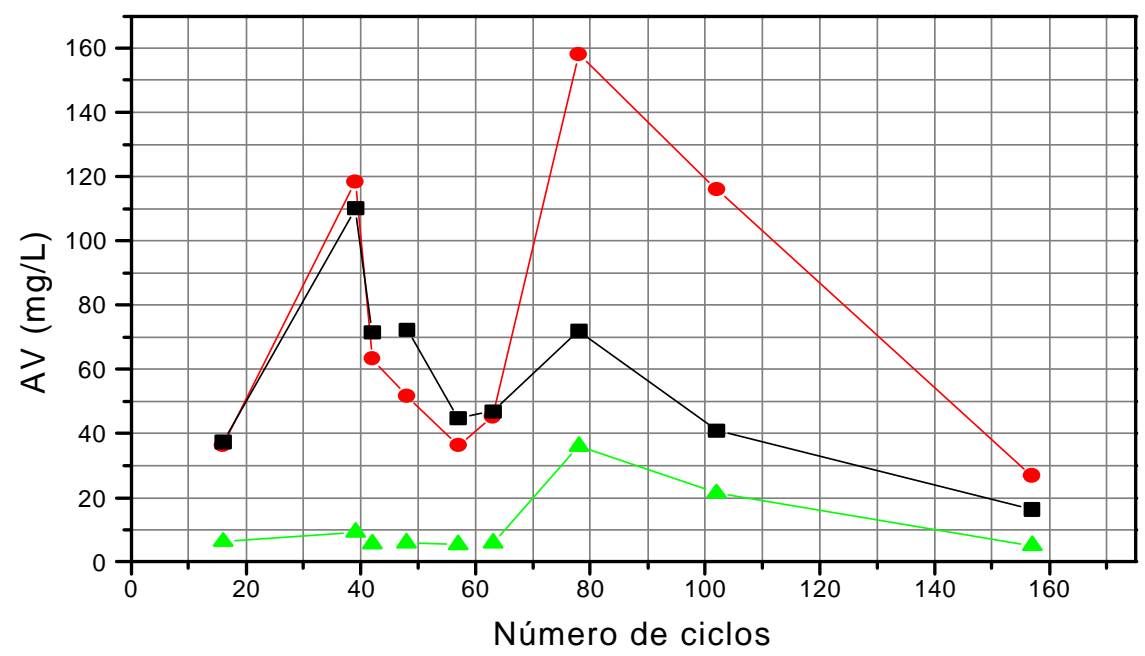

Figura 6.18: Valores da concentração dos ácidos acético (•), propiônico (•) e butírico ( $\left.{ }^{\star}\right)$ obtidos por cromatografia, do efluente durante o período de operação do ASBBR alimentado com $852 \pm 190 \mathrm{mg} / \mathrm{L}$ de glicose e 8 horas de ciclo.

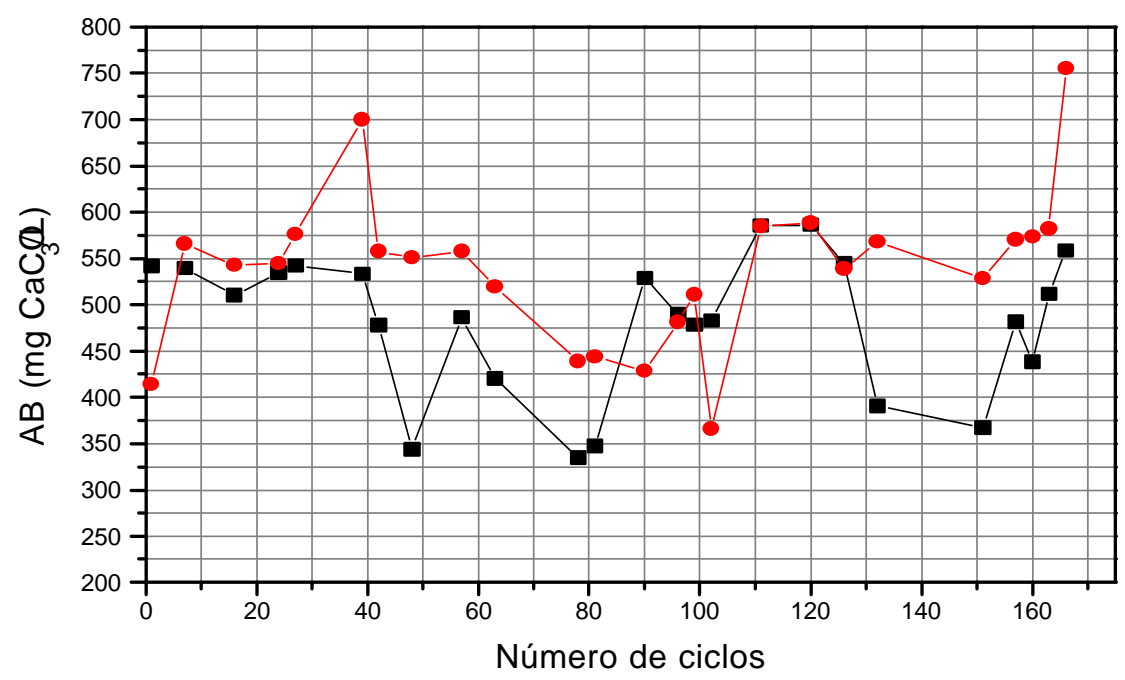

Figura 6.19: Alcalinidade a bicarbonato do afluente $(\boldsymbol{\bullet})$ e efluente $(\bullet)$ durante o período de operação do ASBBR alimentado com $852 \pm 190 \mathrm{mg} / \mathrm{L}$ de glicose e 8 horas de ciclo. 


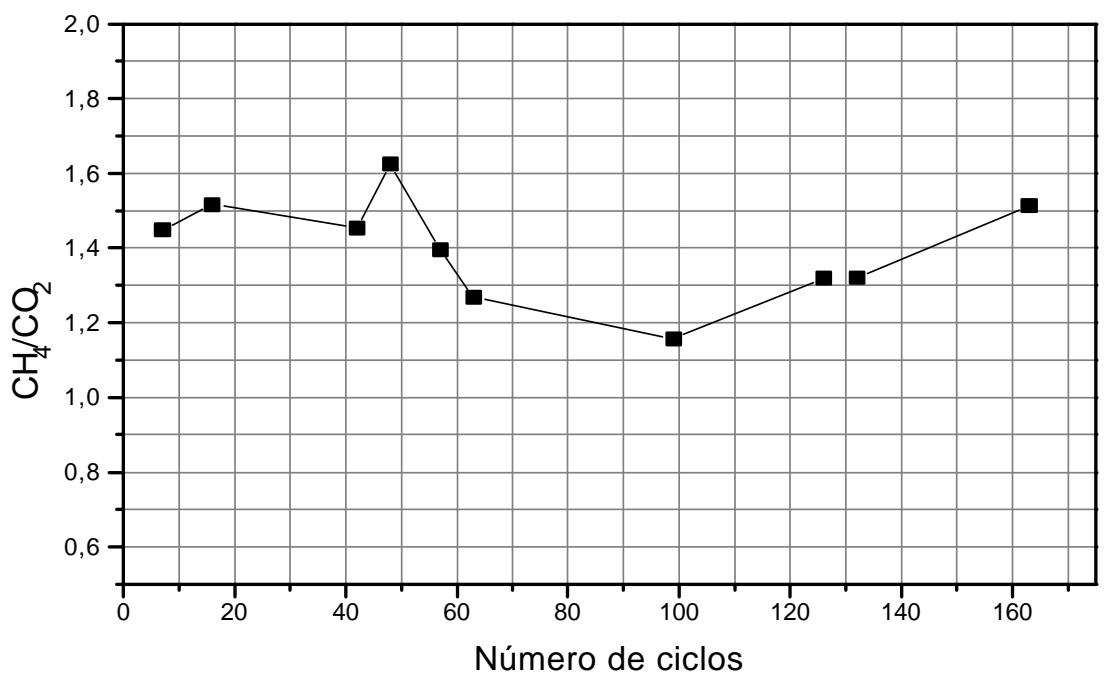

Figura 6.20: Relação entre a composição molar dos gases $\mathrm{CH}_{4}$ e $\mathrm{CO}_{2}$ durante $\mathrm{o}$ período de operação do ASBBR alimentado com $852 \pm 190 \mathrm{mg} / \mathrm{L}$ de glicose e 8 horas de ciclo.

Pode-se observar nas Figuras 6.14 a 6.20 que todas as variáveis de monitoramento oscilaram muito ao longo da operação no efluente indicando instabilidade operacional do sistema. No entanto, nota-se também que as variáveis também oscilaram no afluente, o que pode ter contribuído para esse comportamento mais instável. Particularmente, a concentração de glicose afluente apresentou grande oscilação durante esta fase experimental (Figura 6.14). Este fato pode ser explicado pelo acúmulo de microrganismos nas mangueiras utilizadas na alimentação onde possivelmente começa a degradação da glicose. Uma das justificativas dos valores de DQO serem maiores é que estes valores correspondem a ácidos e possivelmente outros intermediários, tais como ácido láctico, fórmico e alguns álcoois, formados pela degradação da glicose na mangueira, com exceção do décimo dia, que foi erro operacional. As análises de ácidos voláteis realizadas por cromatografia gasosa (Figura 6.16) mostram que as concentrações de ácidos no afluente variaram entre 50 e $80 \mathrm{mg} / \mathrm{L}$. No afluente, os ácidos presentes foram o acético, em maior quantidade, propiônico e butírico (Figura 6.17).

Observa-se na Figura 6.15 que a eficiência na remoção de DQO do reator decai subitamente a partir do $63^{\circ}$ ciclo, e depois aumenta indicando uma instabilidade do reator, que pode ser explicada pelo acúmulo de ácidos no afluente e efluente durante a batelada (Figura 6.16). Porém, durante este período de operação do ASBBR a quantidade do um material viscoso, semelhante a polímeros extracelulares (EPS), aumentou ficando aderido por todas as partes do reator, inclusive no vidro, e não foi liberado. No entanto, não foi possível concluir qual a composição deste material. 
Uma possível explicação para a instabilidade do reator neste período foi a presença deste material viscoso que pode ter interferido na hidrodinâmica do reator e na transferência de massa do meio líquido para a biopartícula, dificultando o estabelecimento de equilíbrio entre os organismos produtores e consumidores de ácidos voláteis.

Tendo em vista os problemas com a degradação da glicose nas mangueiras de alimentação e descarte, as mesmas passaram a ser trocadas e lavadas com água duas vezes por semana a partir do ciclo 90 .

A partir do momento em que as mangueiras começaram a ser trocadas, observou-se que a eficiência na remoção da DQO começou aumentar chegando a atingir valores entre 75\% e 90\% (Figura 6.15) apresentando uma rápida recuperação na estabilidade do processo.

BRITO et al. (1997) tratando água residuária sintética contendo $10 \%$ de glicose e 90\% de ácido acético, propiônico e butírico, na proporção 2:1:1, com DQO próxima de 1000 $\mathrm{mg} / \mathrm{L}$ obtiveram uma eficiência de remoção de DQO entre $60 \%$ e $70 \%$ com tempos de reação entre 5 e 6 horas.

Na Figura 6.16 observa-se que a concentração dos ácidos voláteis totais do efluente variou de $100 \mathrm{mg} / \mathrm{L}$ a $300 \mathrm{mg} / \mathrm{L}$. Os ácidos acético, propiônico e butírico estão em maiores concentrações (Figura 6.18). Essa grande variação na concentrações dos ácidos no efluente, indica o início de instabilidade no sistema de degradação anaeróbia da matéria orgânica.

Na Figura 6.19 pode-se verificar que a alcalinidade a bicarbonato no efluente é levemente maior que no afluente durante o período de operação, indicando ainda um bom desempenho do processo anaeróbio. A fração molar de $\mathrm{CH}_{4}$ é maior que $\mathrm{CO}_{2}$ ao final do ciclo, variando de 1,15 a 1,6 (Figura 6.20).

Após 147 ciclos corridos (50 dias) de operação realizou-se o perfil temporal e mudou-se a concentração de glicose para, aproximadamente, $2000 \mathrm{mg} / \mathrm{L}$.

Durante os três dias de realização de perfil temporal foi feita a troca das mangueiras antes da primeira batelada do dia para garantir que não houvesse degradação durante o enchimento do reator. Os resultados dos perfis estão representados nas Figuras 6.21 a 6.25. 


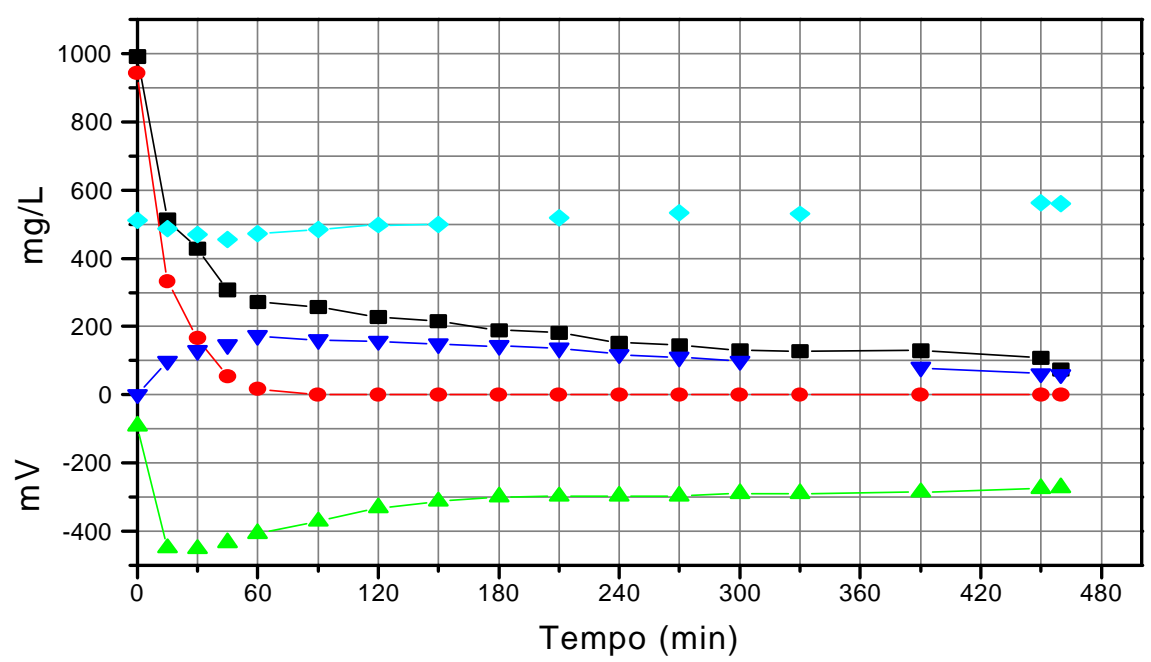

Figura 6.21: Perfil temporal de DQO (•), glicose $(\bullet)$, alcalinidade a bicarbonato $(\diamond)$, $\mathrm{AVT}_{\mathrm{c}}\left({ }^{\vee}\right)$ e potencial redox $(\stackrel{\wedge}{)}$ do ASBBR alimentado com $852 \pm 190 \mathrm{mg} / \mathrm{L}$ de glicose e 8 horas de ciclo.

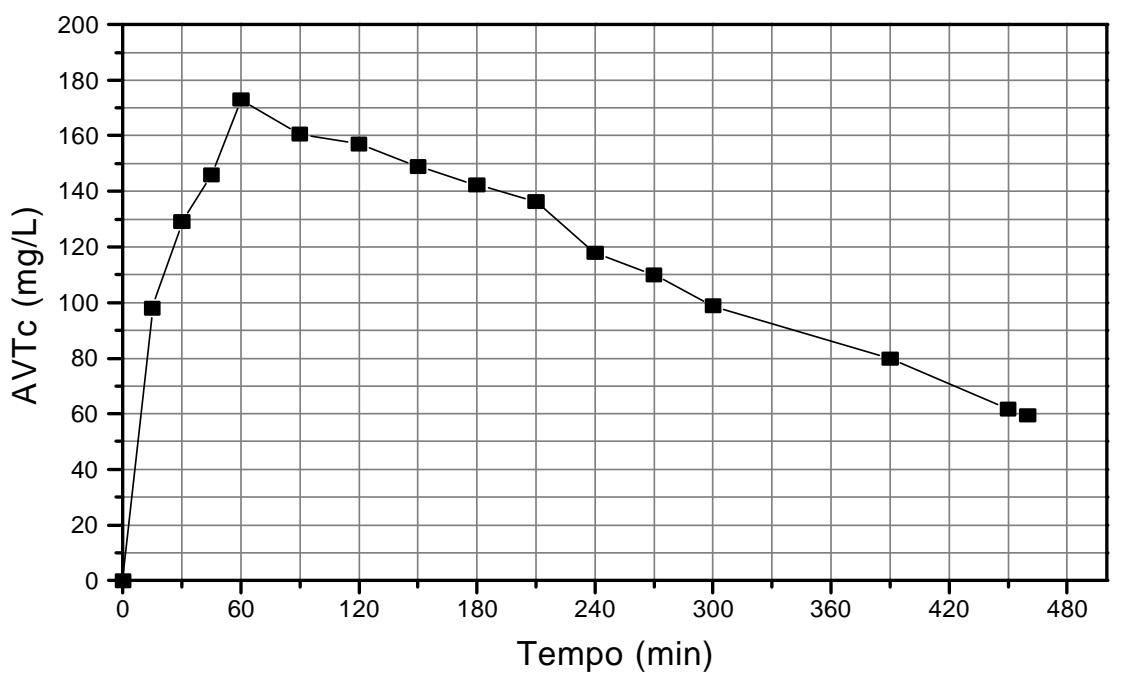

Figura 6.22: Concentrações dos AVT, determinado por cromatografia, durante o perfil temporal do ASBBR alimentado com $852 \pm 190 \mathrm{mg} / \mathrm{L}$ de glicose e 8 horas de ciclo. 


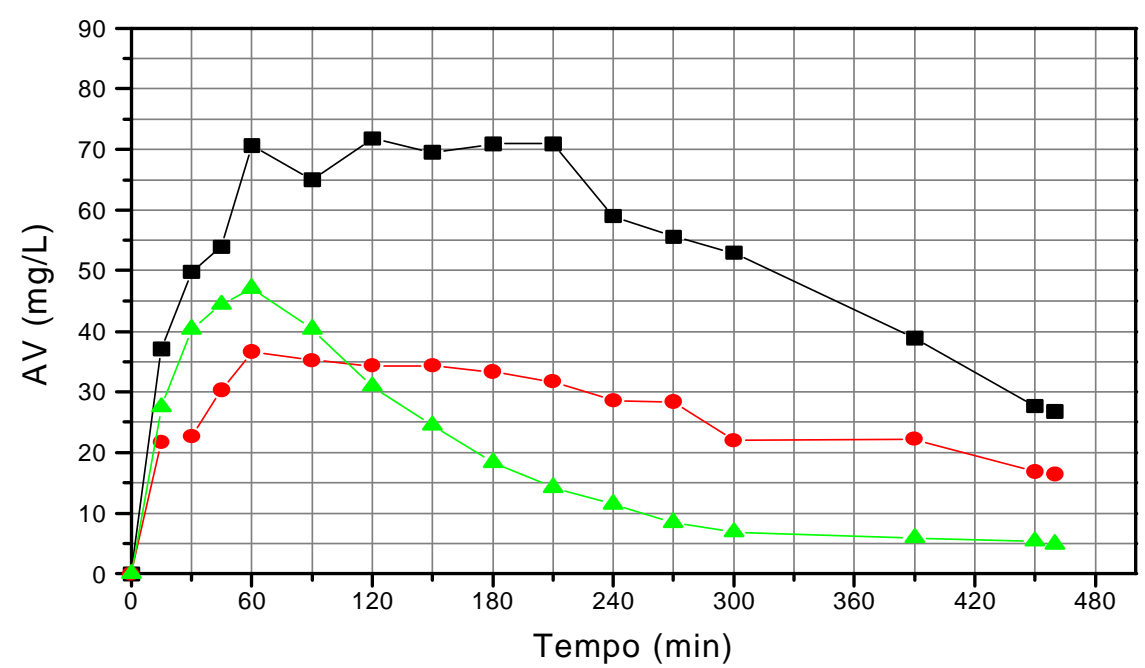

Figura 6.23: Concentrações dos ácidos acético $(\bullet)$, propiônico $(\bullet)$ e butírico $(\stackrel{\bullet}{)}$ durante o perfil temporal do ASBBR alimentado com $852 \pm 190 \mathrm{mg} / \mathrm{L}$ de glicose e 8 horas de ciclo.

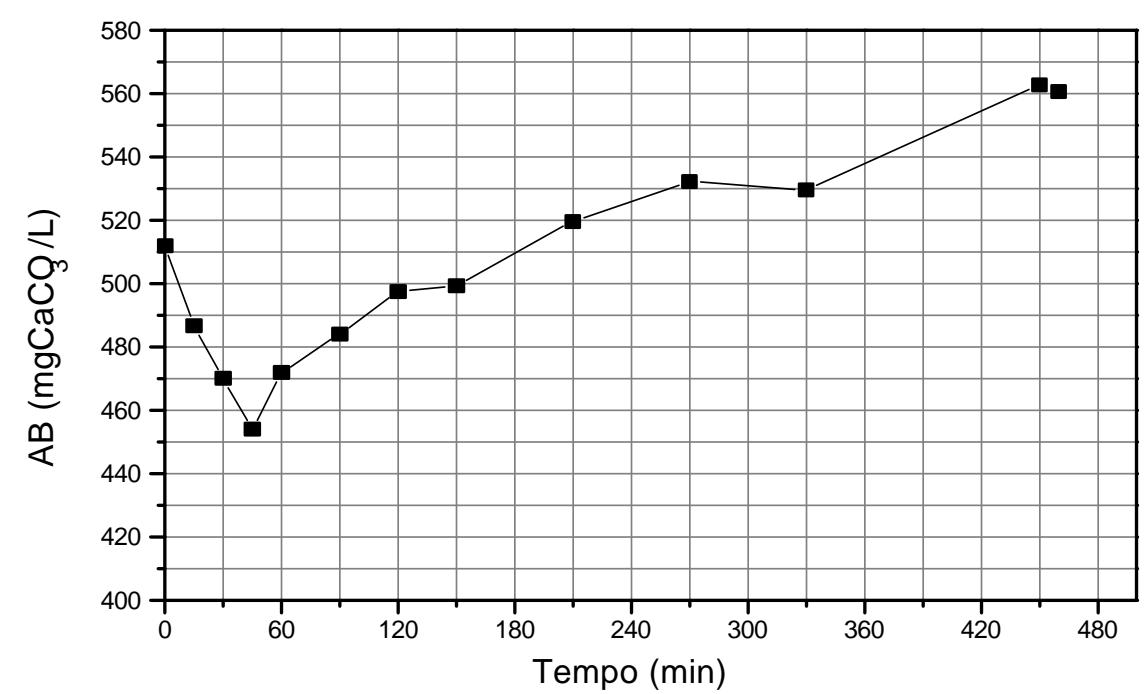

Figura 6.24: Valores da alcalinidade a bicarbonato determinado durante o perfil temporal do ASBBR alimentado com $852 \pm 190 \mathrm{mg} / \mathrm{L}$ de glicose e 8 horas de ciclo. 


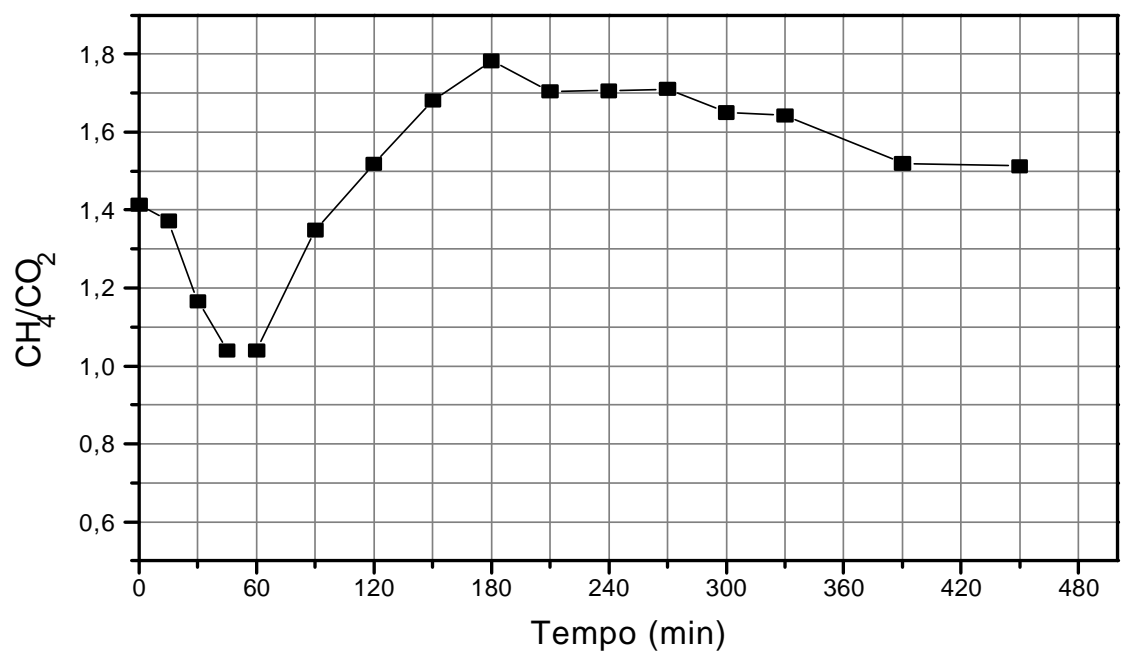

Figura 6. 25: Perfil temporal da composição de gases, representado como a relação de $\mathrm{CH}_{4}$ e $\mathrm{CO}_{2}$, no ASBBR alimentado com $852 \pm 190 \mathrm{mg} / \mathrm{L}$ de glicose e 8 horas de ciclo.

Na Figura 6.21 podem ser observados os perfis temporais do consumo da glicose, DQO, formação de ácidos voláteis, determinados por cromatografia gasosa, alcalinidade a bicarbonato e potencial redox.

Durante a degradação da glicose houve produção simultânea dos ácidos propiônico, acético e butírico em maiores concentrações. Após 60 minutos, o ácido butírico começa a ser consumido rapidamente chegando a concentrações abaixo de $5 \mathrm{mg} / \mathrm{L}$. Entre 60 e 210 minutos a velocidade de produção dos ácidos propiônico e acético é igual a velocidade de consumo, após 210 minutos de operação a velocidade de consumo dos ácidos passa a ser maior que a de produção. Esse fato é explicado pela sequiência da rota de degradação de intermediários, na qual o ácido acético está sendo produzido a partir da degradação do ácido butírico. N Figura 6.23 esse fato pode ser confirmado pela valores da concentração do ácido acético que só decai significantemente após a concentração do ácido butírico atingir valores baixos. Os valores da DQO também decaem, porém não correspondem aos valores dos ácidos que estão sendo formados. A partir dos 240 minutos de operação os valores começam a ser correspondentes. O mesmo foi observado no perfil do ASBBR sendo alimentado com $500 \mathrm{mg} / \mathrm{L}$ de glicose. Uma possível explicação é a formação de intermediários que não foram determinados.

Em estudos realizados por BAGLEY \& BRODKORB (1999) e por SHIZAS \& BRAGLEY (2001) com concentração de 2000 mg de glicose/L, a glicose foi degradada em 4 h e houve acúmulo dos ácidos propiônico e acético. No entanto a temperatura do reator foi mantida em torno de $22^{\circ} \mathrm{C}$, que pode justificar o maior tempo na degradação da matéria 
orgânica.

Uma outra possível explicação pelo menor tempo de degradação da glicose é o fato da biomassa estar imobilizada em espumas de poliuretano, enquanto que no trabalho de BAGLEY \& BRODKORB (1999) o lodo estava na forma granular. Segundo VARESCHE et al. (1997), a conformação da biomassa na espuma parece otimizar os fluxos de substratos primários e produtos intermediários entre as espécies dentro das matrizes.

Os valores do potencial redox mantiveram -se constantes, próximos de $-300 \mathrm{mV}$, após 120 minutos de reação, similares aos valores obtidos por HARPER \& POHLAND (1986).

O comportamento da alcalinidade a bicarbonato durante um ciclo pode ser observado na Figura 6.24. Há consumo da alcalinidade nos primeiros 60 minutos, ao mesmo tempo em que ocorre a degradação da glicose e a formação de ácidos voláteis. Quando os ácidos começam a ser consumidos, há a produção de $\mathrm{CO}_{2}$ e consequentemente produção da alcalinidade, cujas concentrações finais atingem valores maiores que as iniciais. A produção de $\mathrm{CO}_{2}$ pode ser confirmada pela Figura 6.25, na qual a fração molar decai na primeira hora de operação e em seguida aumenta.

Uma das hipóteses levantadas com relação à produção do material viscoso similar a EPS (polímero extracelular) foi o longo tempo em que os microrganismos ficaram em contato com os ácidos voláteis, pois logo no inicio da alimentação já se observava a presença de ácidos voláteis (Figura 6.22). Segundo CHRYSI \& BRUCE (2002), uma das funções do EPS é a formação de uma barreira de proteção que aumenta a resistência contra efeitos considerados agressivos às células. Uma vez que o reator estava sendo operado constantemente com concentração de ácidos graxos relativamente altas, algumas bactérias não consumidoras dos ácidos podiam estar produzindo EPS como uma forma de proteção. QUAGLIANO (1999) observou que substratos como melaço de cana-de-açúcar, glicose e frutose favorecem a síntese de grandes quantidades de EPS em culturas de Azobacter chroococcum.

Outra hipótese levantada para explicar a produção do EPS é a privação de matéria orgânica por longo tempo, pois após 180 minutos de ciclo o valor da DQO fica abaixo de $200 \mathrm{mg} / \mathrm{L}$. Nesse caso, o EPS atuaria com sendo uma fonte de reserva de matéria orgânica e energia. 


\subsubsection{Operação com aproximadamente $2000 \mathrm{mg} / \mathrm{L}$ de glicose}

Nesta condição operacional começou-se a ter problemas com a filtração de amostras do efluente, indicando arraste de algum material sólido. Foram feitas duas amostragem para a determinação de sólidos totais e sólidos suspensos totais, cujos valores obtidos foram 1,9 \pm $0,4 \mathrm{~g} / \mathrm{L}$ e $0,008 \pm 0,002 \mathrm{~g} / \mathrm{L}$, respectivamente.

Os valores médios de DQO total $\left(\mathrm{DQO}_{\mathrm{t}}\right)$, DQO filtrada $\left(\mathrm{DQO}_{\mathrm{f}}\right)$, concentrações de glicose $\left(\mathrm{C}_{\mathrm{g}}\right)$, alcalinidade a bicarbonato $(\mathrm{AB})$, ácidos voláteis totais, determinados por cromatografia $\left(\mathrm{AVT}_{\mathrm{c}}\right)$ e por titulometria $\left(\mathrm{AVT}_{\mathrm{t}}\right)$, e $\mathrm{pH}$ no afluente e efluente durante o período de operação com aproximadamente $2000 \mathrm{mg} / \mathrm{L}$ de glicose estão apresentados na Tabela 6.3.

Tabela 6.3: Médias de DQO, concentração de glicose, alcalinidade a bicarbonato e ácidos totais $\left(\mathrm{AVT}_{\mathrm{c}}\right.$ e $\left.\mathrm{AVT}_{\mathrm{t}}\right)$ de entrada e saída do ASBBR durante o período de operação com $1943 \pm 205 \mathrm{mg} / \mathrm{L}$ de glicose.

\begin{tabular}{lccccccc}
\hline & $\begin{array}{c}\mathbf{D Q O}_{\mathbf{t}} \\
(\mathbf{m g} / \mathbf{L})\end{array}$ & $\begin{array}{c}\mathbf{D Q O}_{\mathbf{f}} \\
(\mathbf{m g} / \mathbf{L})\end{array}$ & $\begin{array}{c}\mathbf{C}_{\mathbf{g}} \\
(\mathbf{m g} / \mathbf{L})\end{array}$ & $\begin{array}{c}\mathbf{A B} \\
\left(\mathbf{m g C a C O}_{\mathbf{3}} / \mathbf{L}\right)\end{array}$ & $\begin{array}{c}\mathbf{A V T}_{\mathbf{c}} \\
(\mathbf{m g} / \mathbf{L})\end{array}$ & $\begin{array}{c}\mathbf{A V T}_{\mathbf{t}} \\
(\mathbf{m g H A c} / \mathbf{L})\end{array}$ & $\mathbf{p H}$ \\
\hline Valor Médio no & $2005 \pm 83$ & $1989 \pm 118$ & $1943 \pm 205$ & $960 \pm 82$ & $13,2 \pm 25,6$ & $46,1 \pm 7,9$ & $7,9 \pm 0,4$ \\
Afluente & $(20)$ & $(20)$ & $(21)$ & $(21)$ & $(20)$ & $(21)$ & $(21)$ \\
Valor Médio no & $572 \pm 131$ & $467 \pm 142$ & & $827 \pm 67$ & $374 \pm 92$ & $249 \pm 66$ & $6,7 \pm 0,1$ \\
Efluente & $(20)$ & $(20)$ & 0 & $(21)$ & $(20)$ & $(21)$ & $(21)$ \\
\hline
\end{tabular}

( ) número de amostragens.

Nessa condição operacional, também não se detectou glicose no efluente. A alcalinidade a bicarbonato no efluente foi menor que no afluente, indicando uma instabilidade no processo anaeróbio. A concentração de ácidos voláteis foi aproximadamente duas vezes superior a encontrada quando o reator foi operado com $852 \pm 190 \mathrm{mg} / \mathrm{L}$, ou seja, quanto maior a concentração de glicose afluente maior foi o acúmulo de ácidos. Há também uma leve queda no pH do efluente, que manteve-se em torno de 6,7.

Os dados obtidos durante a operação com $1943 \pm 205 \mathrm{mg} / \mathrm{L}$ de glicose estão apresentados nas Figuras 6.26 a 6.33. 


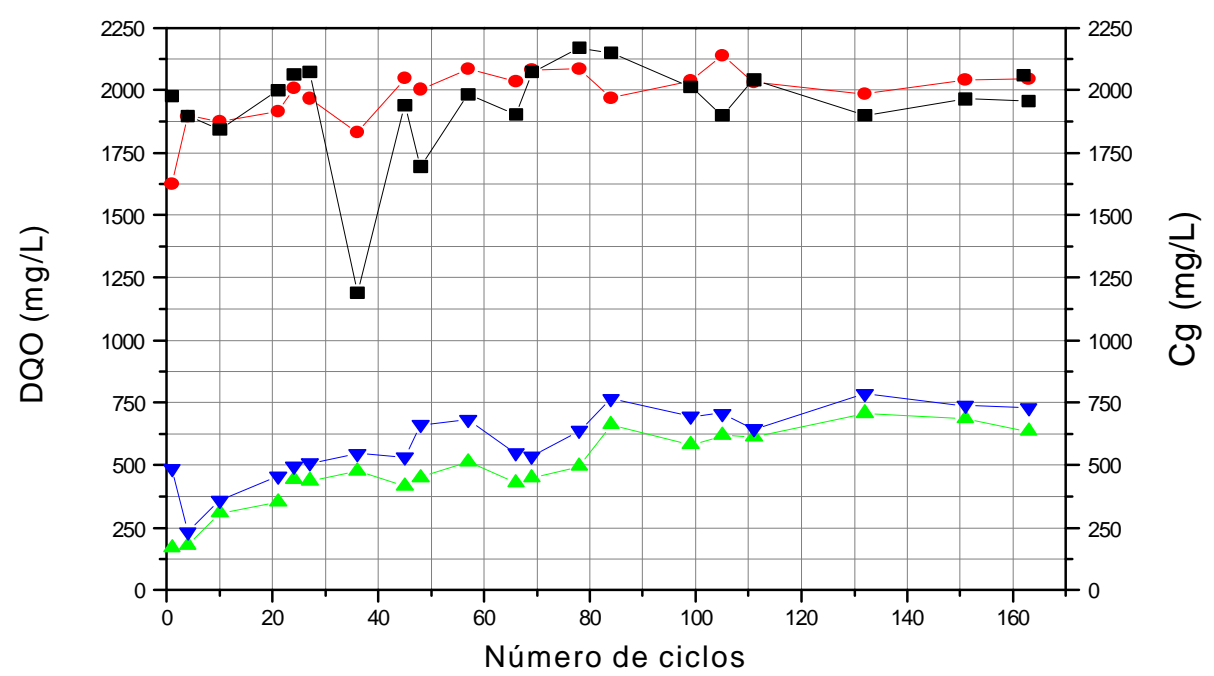

Figura 6.26: Valores da concentração glicose afluente (•) e DQO filtrada do afluente $(\bullet)$ e efluente $\left({ }^{\bullet}\right)$ e DQO bruta do efluente $\left({ }^{\bullet}\right)$ durante o período de operação do ASBBR alimentado com $1943 \pm 205 \mathrm{mg} / \mathrm{L}$ de glicose e 8 horas de ciclo.

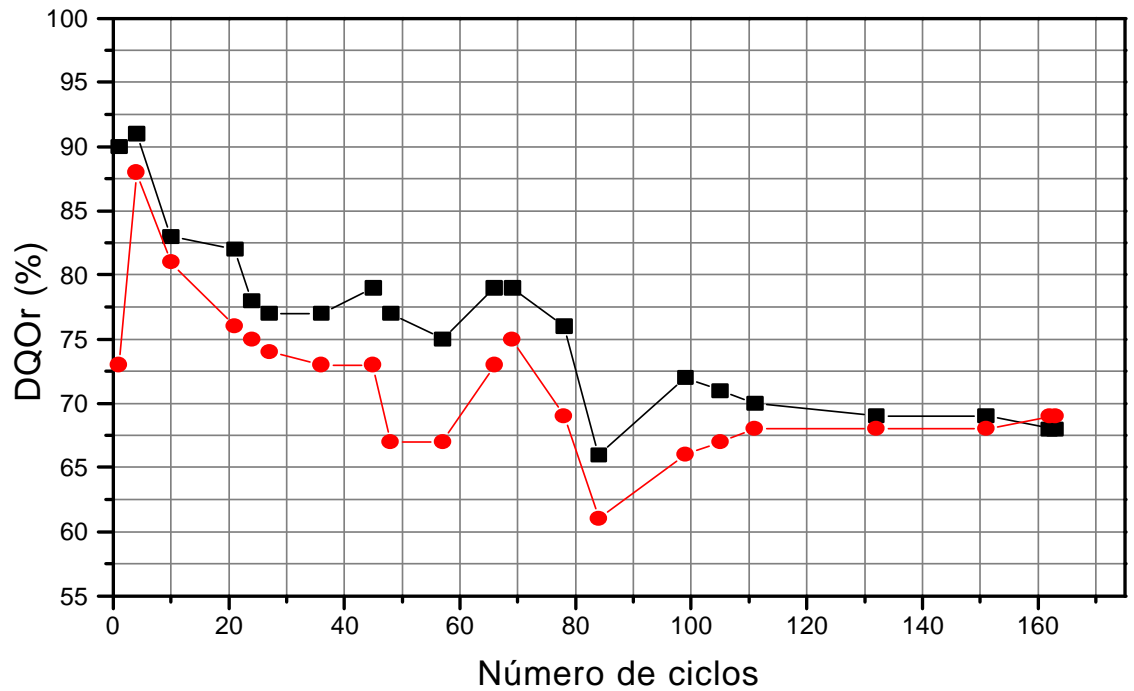

Figura 6.27: Eficiência de redução da DQO bruta $(\bullet)$ e filtrada (•) durante o período de operação do ASBBR alimentado com $1943 \pm 205$ mg/L de glicose e 8 horas de ciclo. 


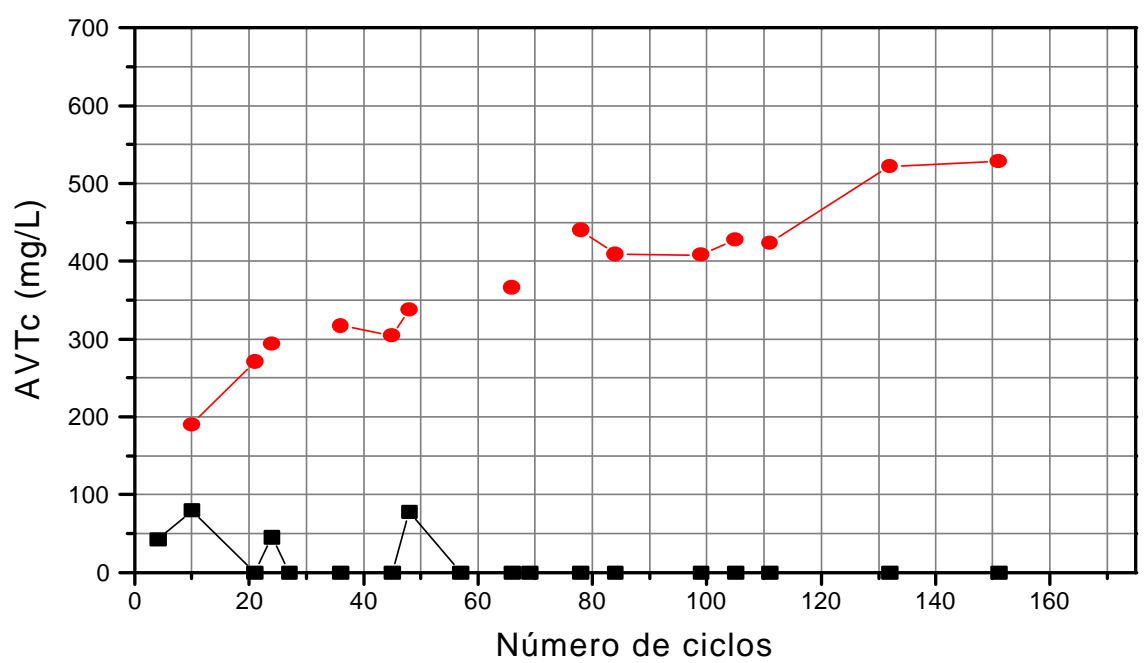

Figura 6.28: Análise da produção de ácidos voláteis totais, obtidos por cromatografia, do afluente $(\bullet)$ e efluente $(\bullet)$ durante o período de operação do ASBBR alimentado com $1943 \pm 205 \mathrm{mg} / \mathrm{L}$ de glicose e 8 horas de ciclo.

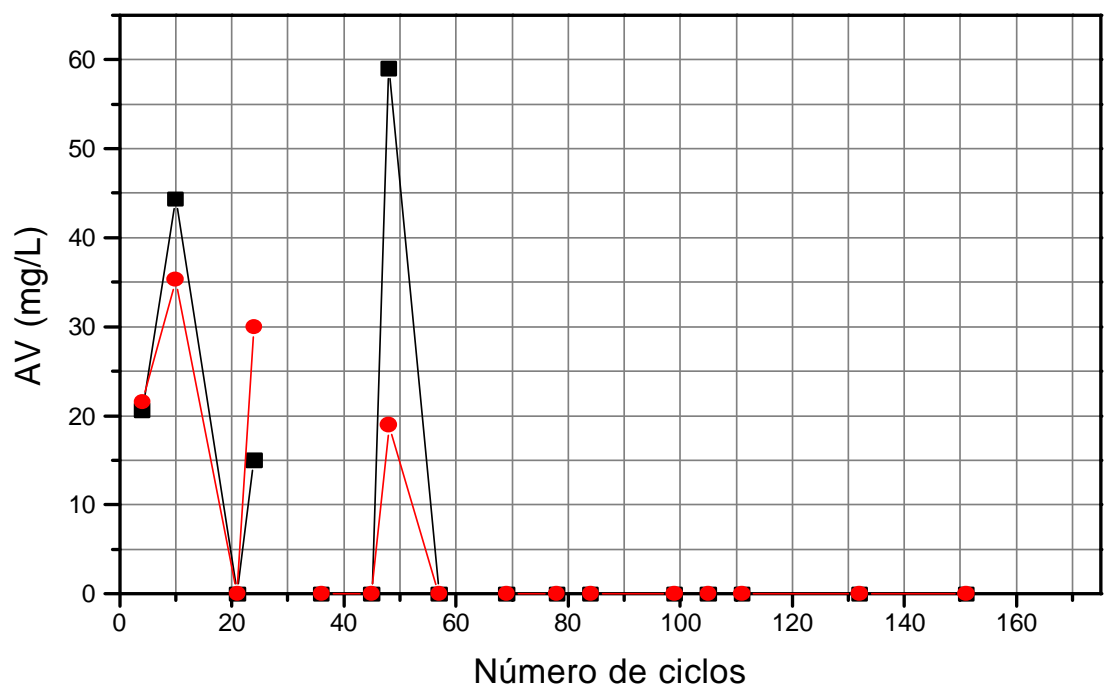

Figura 6.29: Valores da concentração dos ácidos acético (•) e propiônico (•) obtidos por cromatografia, do afluente durante o período de operação do ASBBR alimentado com $1943 \pm 205 \mathrm{mg} / \mathrm{L}$ de glicose e 8 horas de ciclo. 


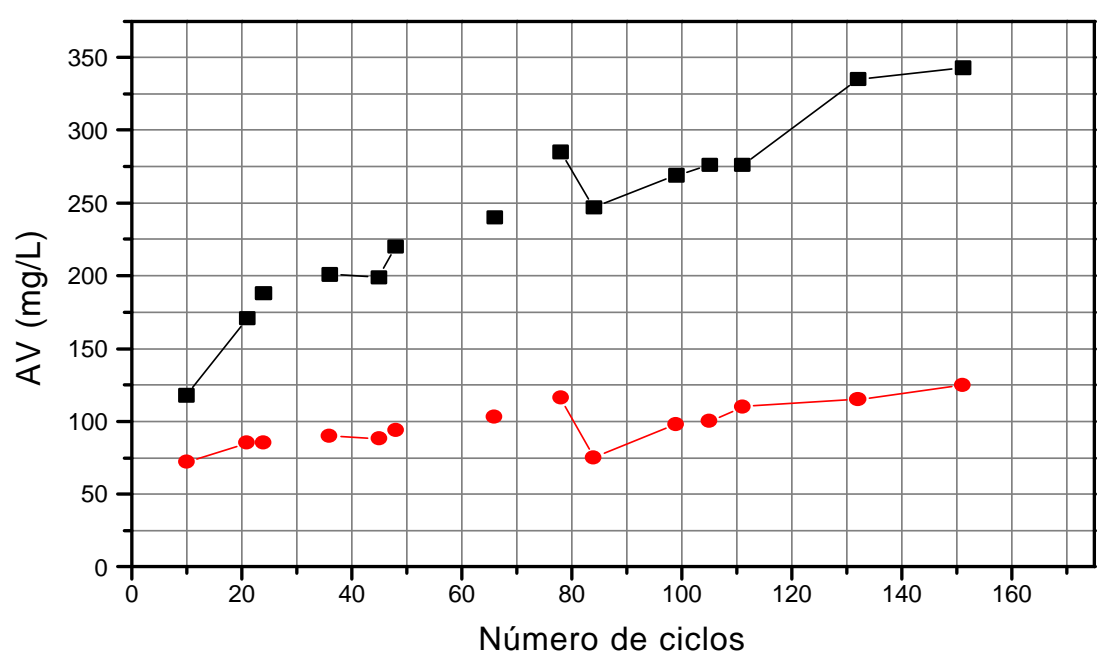

Figura 6.30: Valores da concentração dos ácidos acético (•) e propiônico (•) obtidos por cromatografia, do efluente durante o período de operação do ASBBR alimentado com $1943 \pm 205 \mathrm{mg} / \mathrm{L}$ de glicose e 8 horas de ciclo.

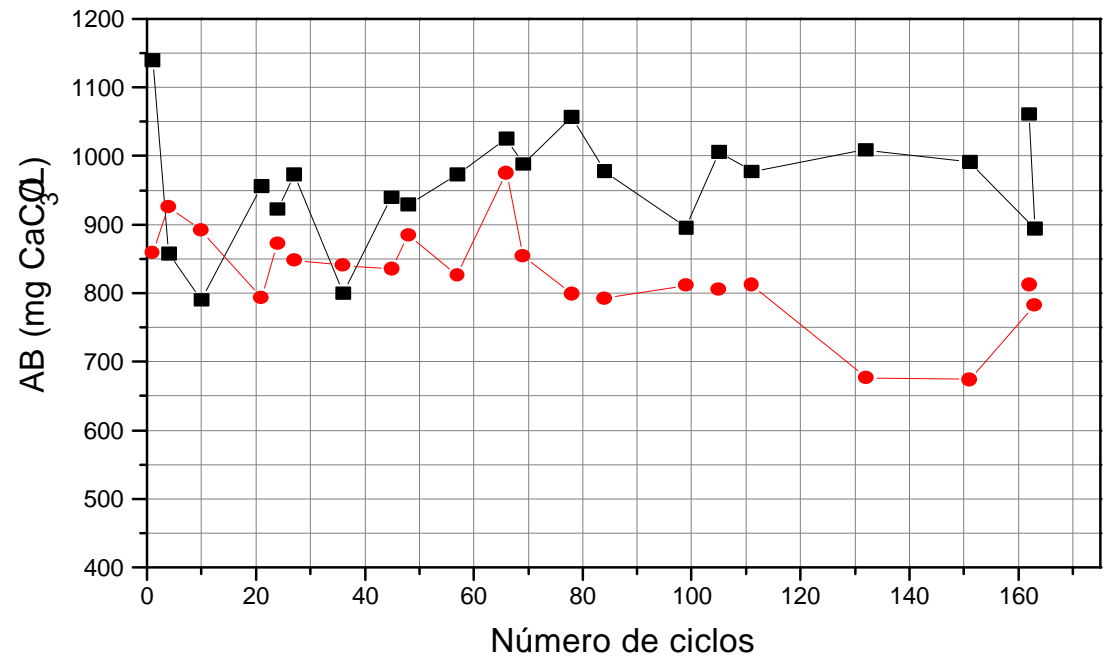

Figura 6.31: Alcalinidade a bicarbonato do afluente $(\bullet)$ e efluente $(\bullet)$ durante o período de operação do ASBBR alimentado com $1943 \pm 205$ mg/L de glicose e 8 horas de ciclo. 


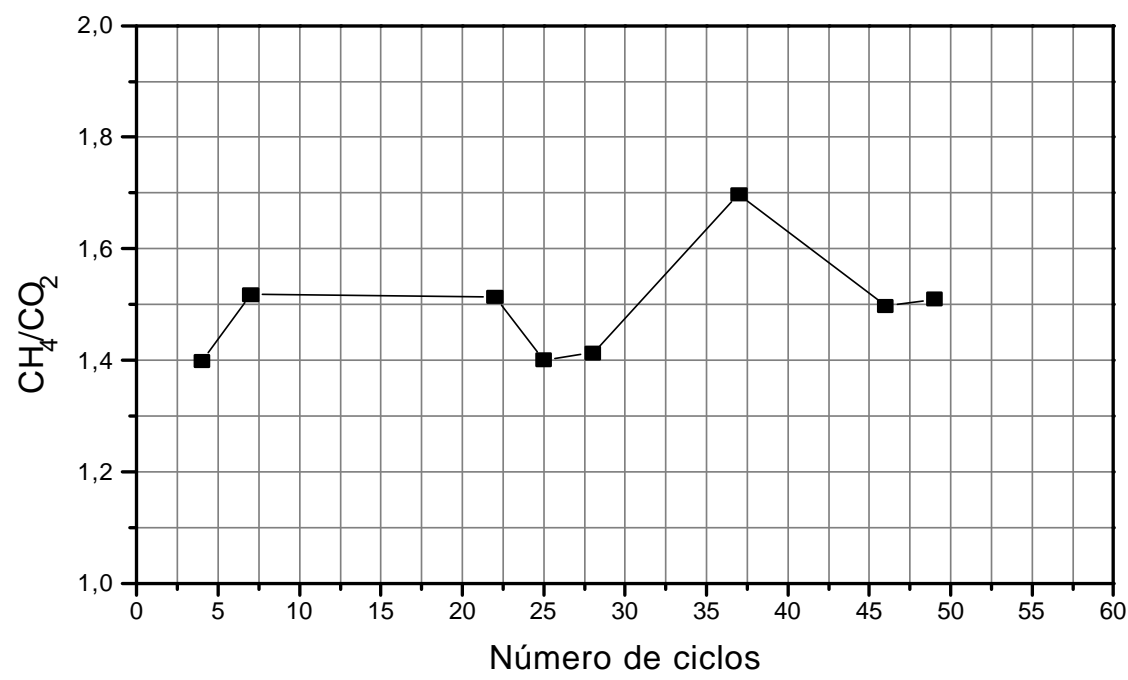

Figura 6. 32: Relação entre a composição molar dos gases $\mathrm{CH}_{4}$ e $\mathrm{CO}_{2}$ durante o período de operação do ASBBR alimentado com $1943 \pm 205 \mathrm{mg} / \mathrm{L}$ de glicose e 8 horas de ciclo.

Devido ao arraste de sólidos, observou-se diferença na eficiência da remoção de DQO total e filtrada, cujos valores estão apresentados na Figura 6.27. A eficiência do ASBBR foi decaindo com o decorrer dos ciclos. No entanto até o último dia de operação o reator atingiu valores acima de 65\% (Figura 6.27).

As concentrações de ácidos encontradas no afluente até o $60^{\circ}$ ciclo (Figura 6.27) foram devidas à acidificação da glicose na bomba de alimentação e os ácidos presentes foram acético e propiônico (Figura 6.29). A partir do ciclo 60, a bomba e as mangueiras foram lavadas com 5 litros de uma solução concentrada de $\mathrm{NaOH}$ e, em seguida, enxaguadas com aproximadamente $15 \mathrm{~L}$ de água, para garantir a total retirada do $\mathrm{NaOH}$, de modo que este não alterasse o $\mathrm{pH}$ do afluente.

Na Figura 6.28 pode-se constatar que as concentrações de ácidos voláteis no efluente aumentou com o tempo de operação, chegando à concentrações próximas de $500 \mathrm{mg} / \mathrm{L}$ nos últimos ciclos. Essa acidificação, com conseqüente perda de eficiência do sistema ao longo do tempo, pode ser resultado da alimentação rápida do sistema, considerando-se que se trabalhou com água residuária de fácil degradação. Isso estaria de acordo com o postulado por BAGLEY \& BRODKORB (1999), que sugerem tempos longos de enchimento do reator para evitar acidificação. No entanto, a acidificação do sistema nesse trabalho pode estar relacionada com o acúmulo do material viscoso, similar a EPS, e não ao fato de se alimentar rapidamente o reator. Nesse caso, o acúmulo desse material seria a principal causa da acidificação. 
Observou-se ao longo das operações que a quantidade de EPS, aparentemente, aumentou, podendo ter interferido na eficiência do reator, permitindo que haja o acúmulo dos ácidos e uma possível instabilidade na seqüência de degradação anaeróbia. Os ácidos presentes em maiores concentrações no efluente foram o acético e o propiônico (Figura 6.30), responsáveis pelo consumo da alcalinidade (Figura 6. 31). No caso de BAGLEY \& BRADKORB (1999), tratando água residuária contendo $2000 \mathrm{mg} / \mathrm{L}$ de glicose com ciclos de 24 horas, as concentrações dos ácidos voláteis chegaram a $500 \mathrm{mg} / \mathrm{L}$ ao final dos ciclos, porém os principais ácidos presentes foram acético e butírico.

Durante todo o período de operação do ASBBR com $1943 \pm 205$ mg/L, observou-se o consumo da alcalinidade a bicarbonato (Figura 6.31) indicando possível desequilíbrio do processo anaeróbio. No entanto, a produção de $\mathrm{CH}_{4}$ foi maior que $\mathrm{CO}_{2}$ (Figura 6.32), cujas frações molares variaram entre 1,4 e 1,7, ou seja, a proporção de $\mathrm{CH}_{4}$ variou de 58,3 \% e 63,0 \%. Isso pode indicar que não houve desestabilização do processo anaeróbio de conversão, mas apenas uma limitação física para consumo dos ácidos formados como resultado do acúmulo do material viscoso sobre as biopartículas.

Com 55 dias (163 ciclos) de operação do ASBBR, nessas condições, o reator ainda não havia atingido a estabilidade operacional, ou seja, observou-se a tendência ao completo desequilíbrio do processo, verificado pelo aumento, aparente, na produção do EPS. Tendo em vista os problemas com o EPS, parou-se de operar o reator com ciclos de 8 horas e recomeçou-se a pesquisa, porém com o objetivo de verificar a causa da produção do EPS.

Levando em consideração as duas hipóteses levantadas anteriormente (item 6.1.2), exposição dos microrganismos por longo período a altas concentrações de ácidos e privação da matéria orgânica, decidiu-se reduzir o tempo dos ciclos para 3 horas.

Essa atuação no processo atendeu a segunda hipótese levantada (privação de matéria orgânica por longo tempo) e objetivou a redução da produção de EPS, reduzindo os problemas hidrodinâmicos e de transferência de massa.

Ao final de cada condição foi feita a quantificação da biomassa, contida nas espumas, obtendo $16,0 \mathrm{~g} \mathrm{SVT/L}$ para todas as condições. 


\subsection{Operação do ASBBR com 3 horas de Ciclo - $2^{\mathrm{a}}$ Etapa}

Nesta etapa operou-se o ASBBR com aproximadamente $500 \mathrm{mg} / \mathrm{L}$ e $1000 \mathrm{mg} / \mathrm{L}$ de glicose com 3 horas de ciclo.

Os perfis temporais foram realizados somente quando se operou com $500 \mathrm{mg} / \mathrm{L}$ de glicose, pois quando o reator estava no $160^{\circ}$ ciclo operando com $1000 \mathrm{mg} / \mathrm{L}$ de glicose o objetivo principal proposto para esta etapa já havia sido atingido, que era a verificação na formação do EPS quando o reator fosse operado com 3 horas de ciclos.

\subsubsection{Operação com aproximadamente $500 \mathrm{mg} / \mathrm{L}$ de glicose}

Os valores médios de DQO total $\left(\mathrm{DQO}_{\mathrm{t}}\right)$, DQO filtrada $\left(\mathrm{DQO}_{\mathrm{f}}\right)$, concentração de glicose $\left(\mathrm{C}_{\mathrm{g}}\right)$, alcalinidade a bicarbonato $(\mathrm{AB})$, ácidos voláteis totais obtidos por cromatografia $\left(\mathrm{AVT}_{\mathrm{C}}\right)$, ácidos voláteis totais obtidos por titulometria $\left(\mathrm{AVT}_{\mathrm{t}}\right)$, cujos valores são dados em miligrama de ácido acético por litro $(\mathrm{mgHAc} / \mathrm{L})$ e $\mathrm{pH}$ no afluente e efluente durante o período de operação com $495 \pm 35 \mathrm{mg} / \mathrm{L}$ de glicose estão descritos na Tabela 6.4.

$\mathrm{Na}$ Tabela 6.4 observa-se uma diferença na $\mathrm{DQO}_{\mathrm{t}}$ e $\mathrm{DQO}_{\mathrm{f}}$ do efluente, obtendo-se uma maior eficiência de remoção na $\mathrm{DQO}_{\mathrm{f}}$. Isso não ocorreu no caso de ciclo de 8 horas para concentração de glicose de aproximadamente $500 \mathrm{mg} / \mathrm{L}$, já indicando que a operação com ciclo de 3 horas apresentaria comportamento diferente do observado anteriormente.

A concentração efluente glicose foi igual a zero em todas as amostragens e a alcalinidade a bicarbonato no efluente foi ligeiramente menor que a observada no afluente. A concentração de ácidos voláteis no efluente foi maior que a observada no efluente devido ao curto tempo de ciclo aplicado.

Tabela 6.4: Médias de DQO, concentração de glicose, alcalinidade a bicarbonato e ácidos totais $\left(\mathrm{AVT}_{\mathrm{c}}\right.$ e $\left.\mathrm{AVT}_{\mathrm{t}}\right)$ de entrada e saída do ASBBR durante o período de operação com $495 \pm 35 \mathrm{mg} / \mathrm{L}$ de glicose e 3 horas de ciclo.

\begin{tabular}{lccccccc}
\hline & $\begin{array}{c}\mathbf{D Q O}_{\mathbf{t}} \\
(\mathbf{m g} / \mathbf{L})\end{array}$ & $\begin{array}{c}\mathbf{D Q O}_{\mathbf{f}} \\
(\mathbf{m g} / \mathbf{L})\end{array}$ & $\begin{array}{c}\mathbf{C g} \\
(\mathbf{m g} / \mathbf{L})\end{array}$ & $\begin{array}{c}\mathbf{A B} \\
\left(\mathbf{m g C a C O}_{\mathbf{3}} / \mathbf{L}\right)\end{array}$ & $\begin{array}{c}\mathbf{A V T}_{\mathbf{c}} \\
(\mathbf{m g} / \mathbf{L})\end{array}$ & $\begin{array}{c}\mathbf{A V T}_{\mathbf{t}} \\
(\mathbf{m g H A c} / \mathbf{L})\end{array}$ & $\mathbf{p H}$ \\
\hline Valor Médio no & $520 \pm 24$ & $521 \pm 32$ & $495 \pm 35$ & $239 \pm 18$ & 0 & $21 \pm 3$ & $7,4 \pm 0,1$ \\
Afluente & $(7)$ & $(7)$ & $(7)$ & $(7)$ & & $(7)$ & $(7)$ \\
Valor Médio no & $193 \pm 32$ & $150 \pm 20$ & 0 & $224 \pm 30$ & $157 \pm 33$ & $61 \pm 22$ & $6,6 \pm 0,1$ \\
Efluente & $(7)$ & $(7)$ & & $(7)$ & $(7)$ & $(7)$ & $(7)$ \\
\hline
\end{tabular}

( ) número de amostragens. 
A variação dos parâmetros obtidos durante a operação do ASBBR com $495 \pm 35$ mg/L de glicose e com ciclo de 3 horas, podem ser observados nas Figuras 6.33 a 6.37 .

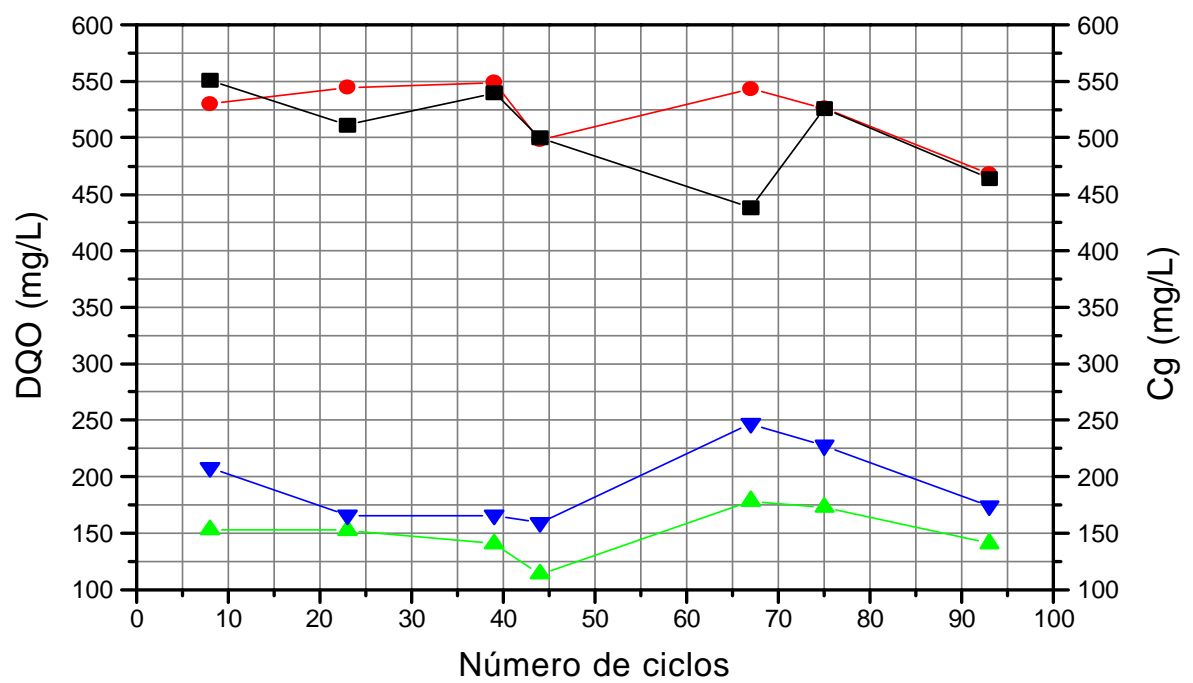

Figura 6.33: Valores de glicose afluente (•) e DQO filtrada do afluente $(\bullet)$ e efluente $\left({ }^{\wedge}\right)$ e DQO bruta do efluente $\left({ }^{\vee}\right)$ durante o período de operação do ASBBR alimentado com $495 \pm 35 \mathrm{mg} / \mathrm{L}$ de glicose e 3 horas de ciclo.

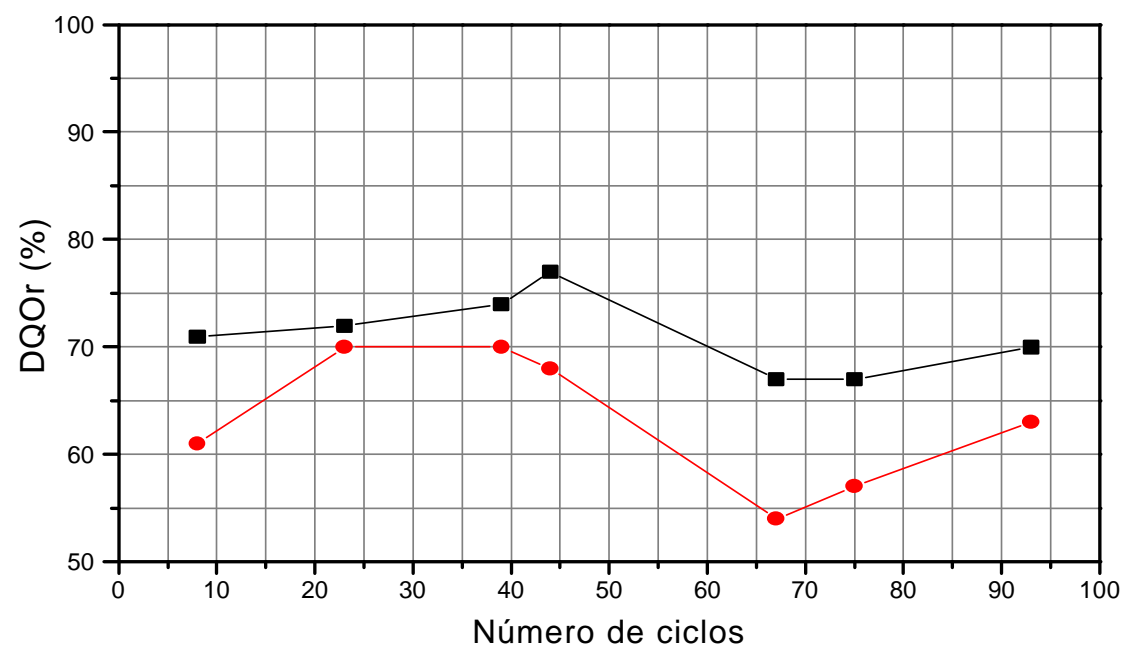

Figura 6.34: Eficiência de remoção de DQO total (•) e DQO filtrada (•) durante o período de operação do ASBBR alimentado com $495 \pm 35 \mathrm{mg} / \mathrm{L}$ de glicose e 3 horas de ciclo. 


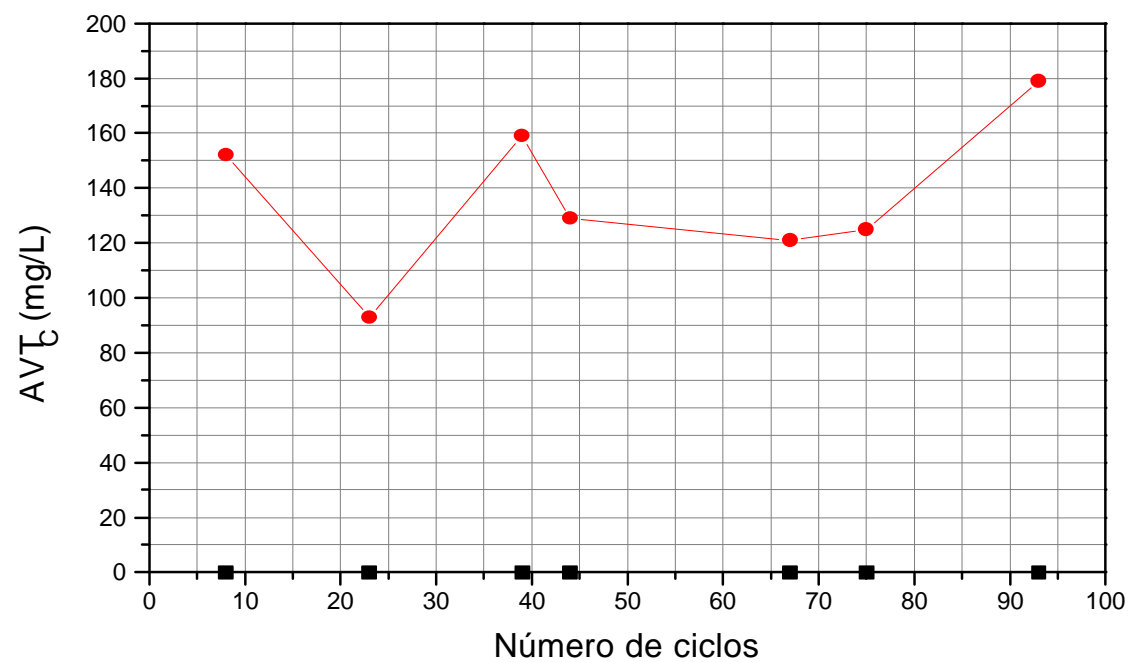

Figura 6.35: Valores da concentração de ácidos totais, obtidos por cromatografia, do afluente $(\bullet)$ e do efluente $(\bullet)$ durante o período de operação do ASBBR alimentado com 495 $\pm 35 \mathrm{mg} / \mathrm{L}$ de glicose e 3 horas de ciclo.

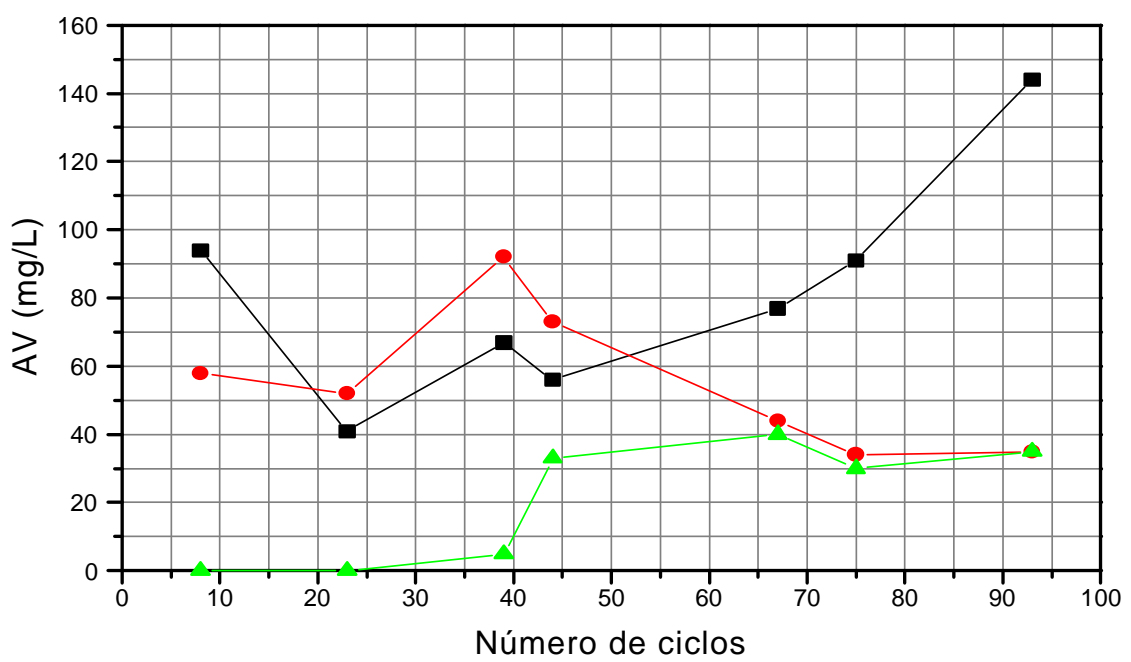

Figura 6.36: Valores das concentrações dos ácidos acético $(\bullet)$, propiônico $(\bullet)$ e butírico $(\stackrel{\wedge}{)}$ no efluente obtidos durante o período de operação do ASBBR alimentado com $495 \pm 35 \mathrm{mg} / \mathrm{L}$ de glicose e 3 horas de ciclo. 


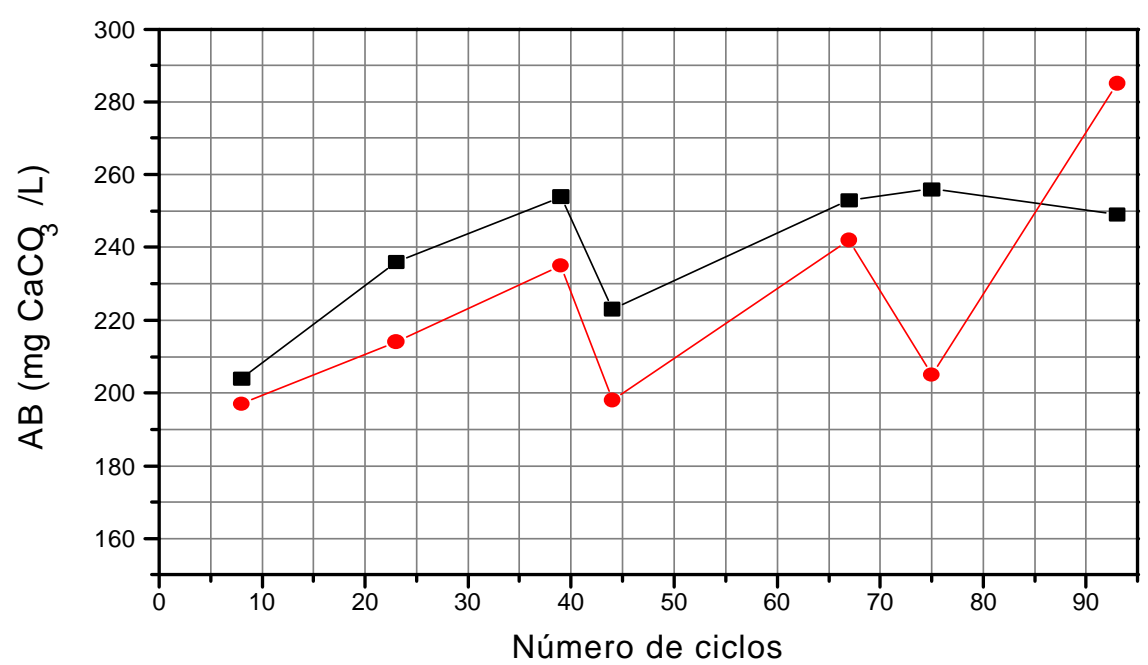

Figura 6.37: Alcalinidade a bicarbonato do afluente $(\bullet)$ e do efluente $(\bullet)$ durante o período de operação do ASBBR alimentado com $495 \pm 35 \mathrm{mg} / \mathrm{L}$ de glicose e 3 horas de ciclo.

As diferenças nos valores da $\mathrm{DQO}_{\mathrm{t}}$ e $\mathrm{DQO}_{\mathrm{f}}$ obtidos durante a operação podem ser observados na Figura 6.34. A eficiência do ASBBR tratando $495 \pm 35 \mathrm{mg} / \mathrm{L}$ de glicose em 3 horas de ciclo se mantém numa faixa entre $60 \%$ e $75 \%$ até o $45^{\circ}$ ciclo. A partir desse ciclo a eficiência decai, ficando entre $50 \%$ e $60 \%$. Após o $44^{\circ}$ ciclo observou-se o começo da produção do EPS, podendo este ter começado a interferir na eficiência do reator. É importante ressaltar que a produção de EPS com ciclo de 8 horas e concentração de glicose de aproximadamente $500 \mathrm{mg} / \mathrm{L}$ foi imperceptível. Dessa forma, a primeira condição operacional, após a redução do tempo de ciclo, já demonstrava que a hipótese levantada poderia não ser comprovada.

A concentração de ácidos voláteis totais no efluente (Figura 6.35) esteve entre 100 $\mathrm{mg} / \mathrm{L}$ e $180 \mathrm{mg} / \mathrm{L}$, valores acima do obtido após três horas de ciclo quando o reator foi operado com ciclo total de 8 horas (Figura 6.10), indicando que a diminuição do tempo do ciclo parece ter efeito negativo no processo. Os ácidos presentes no efluente foram acético, propiônico e butírico, sendo que a presença do ácido butírico foi observada somente a partir do $44^{\circ}$ ciclo (Figura 6.36).

Durante todo o período de operação do ASBBR, a alcalinidade a bicarbonato no efluente foi menor que no afluente (Figura 6.37), devido as maiores concentrações de ácidos no efluente.

Após 93 ciclos de operação, foram realizados os perfis temporais de $\mathrm{DQO}_{\mathrm{f}}$, glicose, AVTc, AB e potencial redox, que podem ser observados nas Figuras 6.38 a 6.42 . 


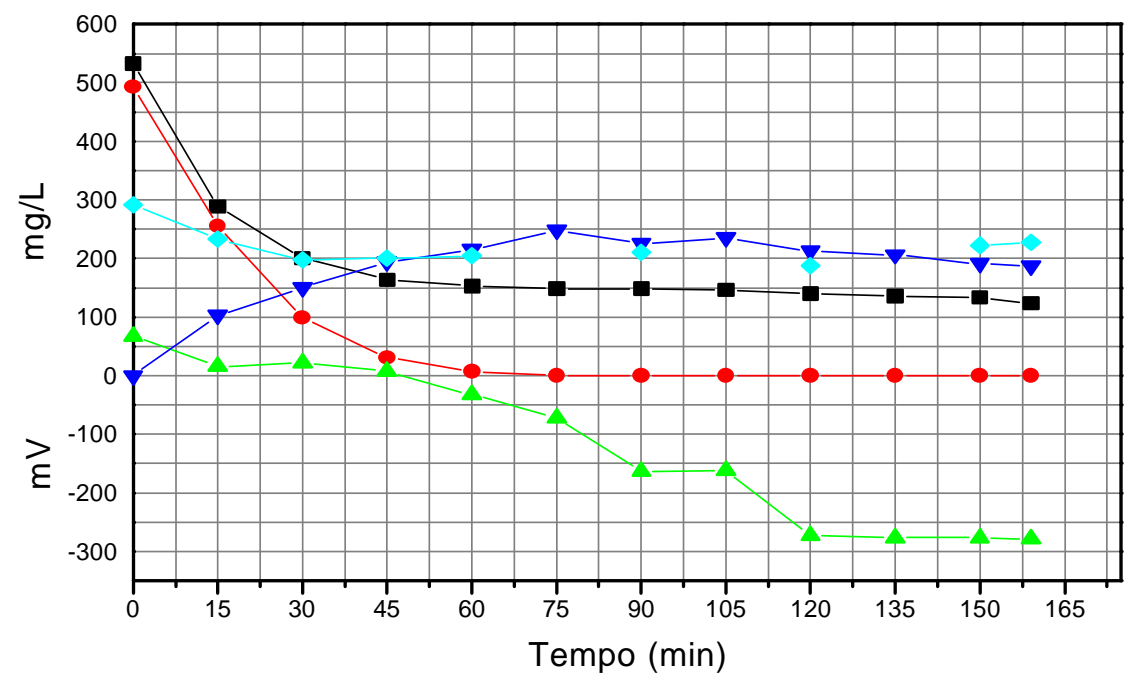

Figura 6.38: Perfil temporal de DQO (•), glicose $(\bullet)$, AVT pelo método cromatográfico $(\bullet)$, alcalinidade a bicarbonato $(\diamond)$ e potencial redox $(\star)$ do ASBBR alimentado com $495 \pm 35 \mathrm{mg} / \mathrm{L}$ de glicose e 3 horas de ciclo.

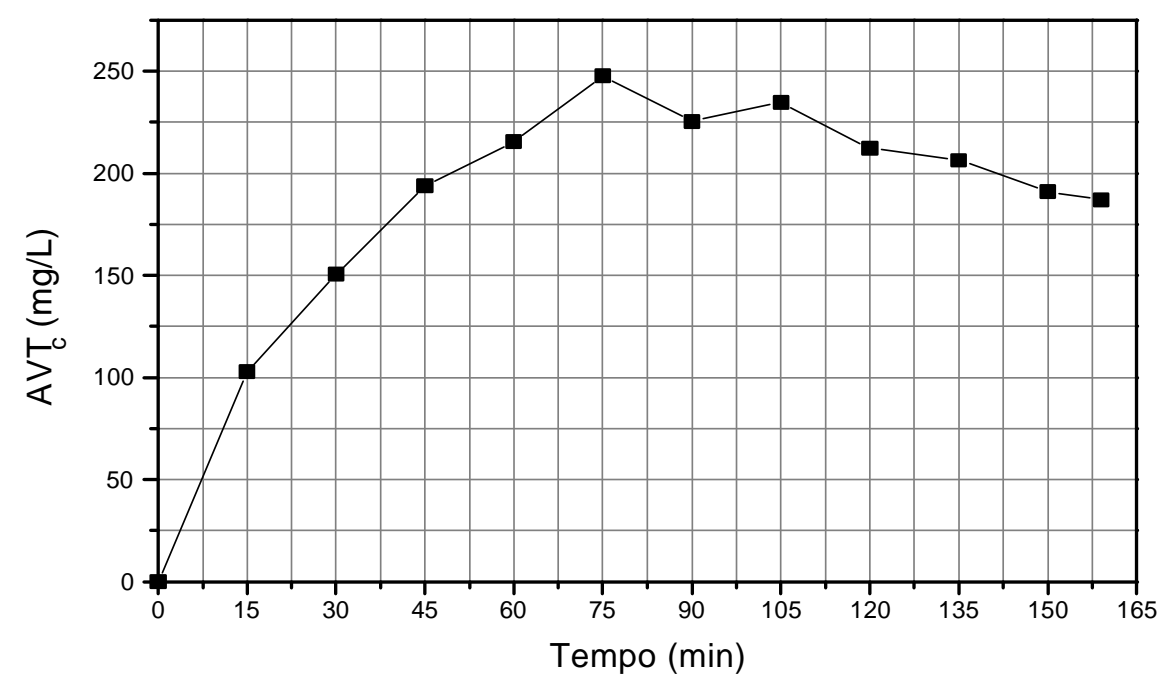

Figura 6.39: Concentrações dos AVT, determinado por cromatografia, durante o perfil temporal do ASBBR alimentado com $495 \pm 35 \mathrm{mg} / \mathrm{L}$ de glicose e 3 horas de ciclo. 


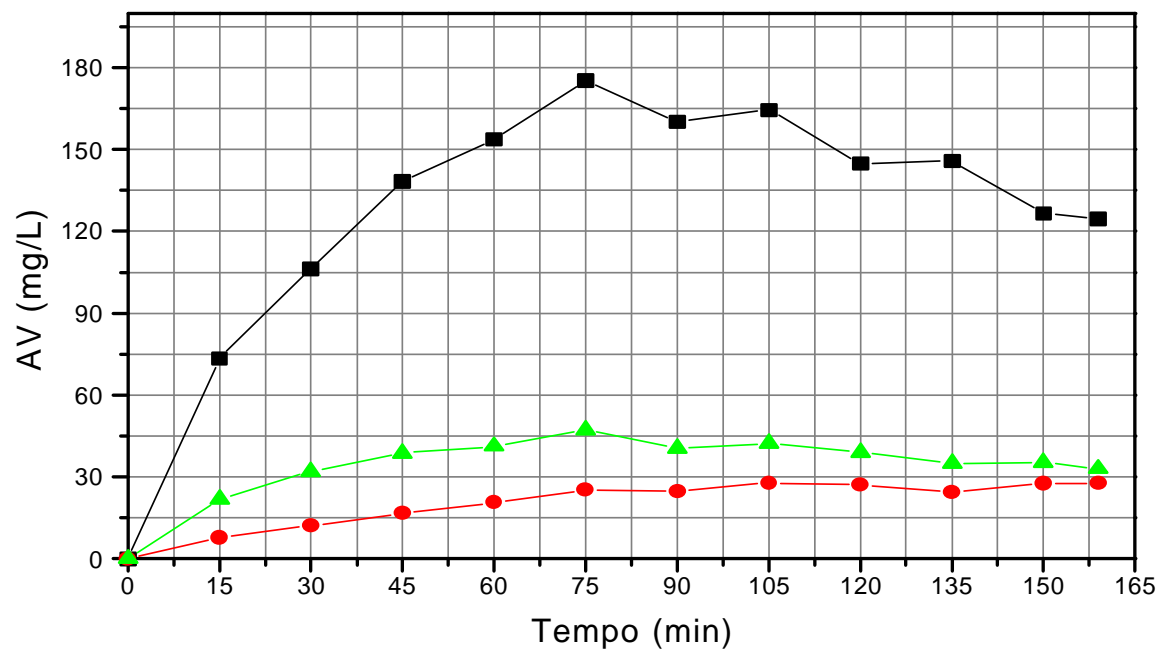

Figura 6.40: Concentrações dos ácidos acético $(\bullet)$, propiônico $(\bullet)$ e butírico $(\stackrel{\bullet}{)}$ durante o perfil temporal do ASBBR alimentado com $495 \pm 35 \mathrm{mg} / \mathrm{L}$ de glicose e 3 horas de ciclo.

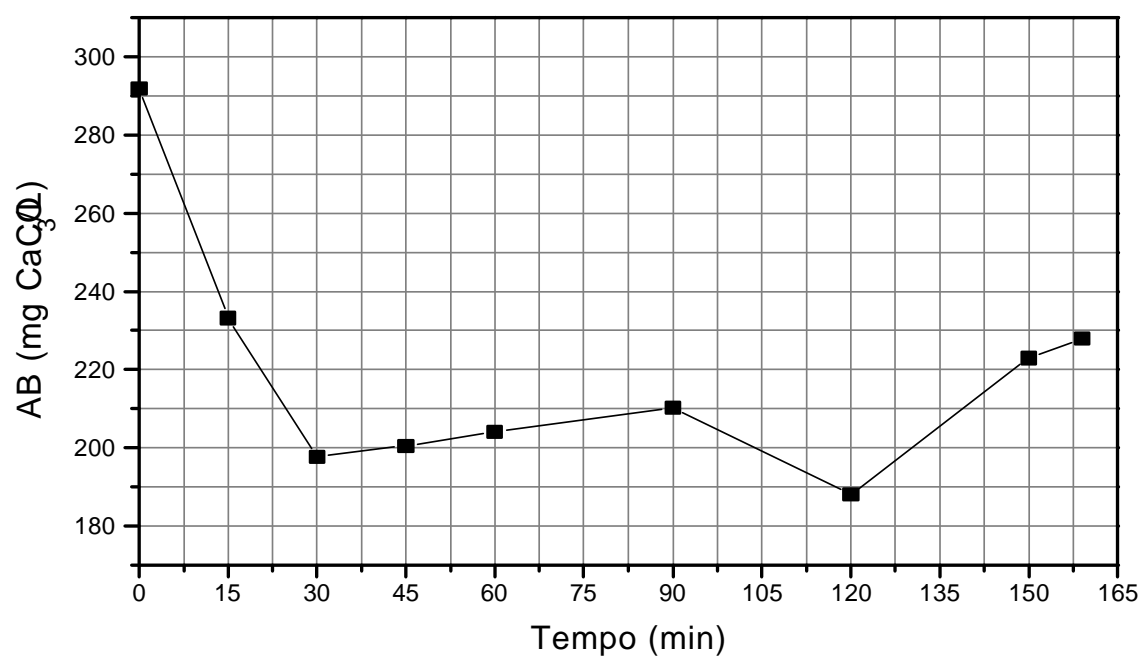

Figura 6.41: Valores da alcalinidade a bicarbonato determinado durante o perfil temporal do ASBBR alimentado com $495 \pm 35 \mathrm{mg} / \mathrm{L}$ de glicose e 3 horas de ciclo. 


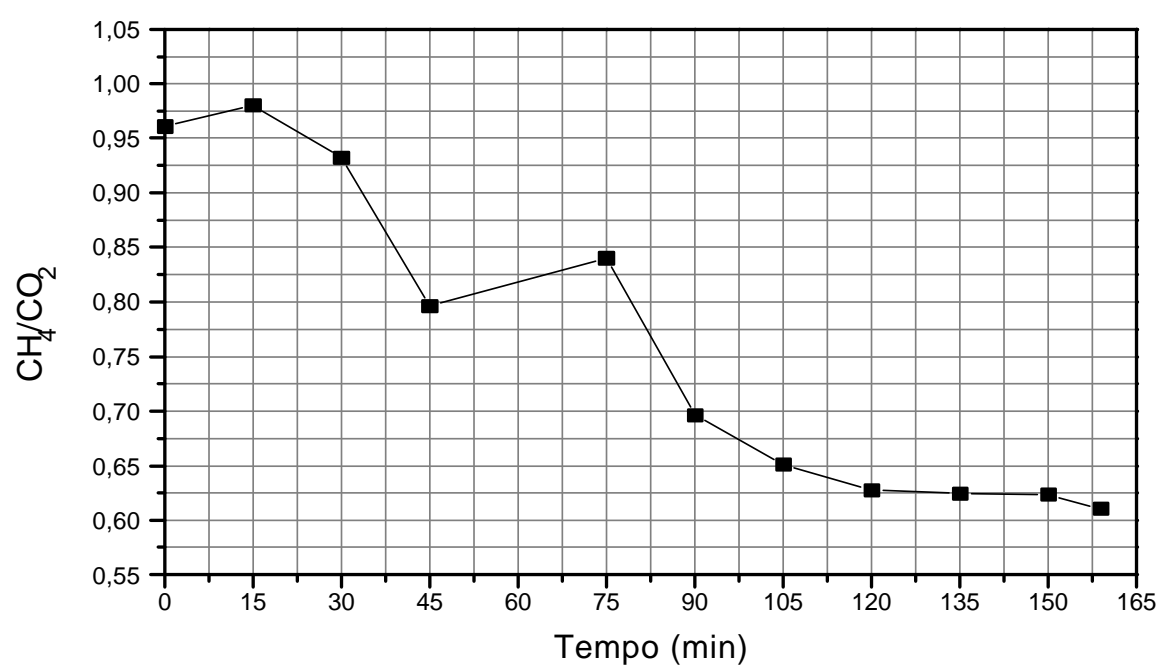

Figura 6.42: Perfil da composição de gases, representado como a relação de $\mathrm{CH}_{4} \mathrm{e}$ $\mathrm{CO}_{2}$, no ASBBR alimentado com $495 \pm 35 \mathrm{mg} / \mathrm{L}$ de glicose e 3 horas de ciclo.

Os perfis temporais apresentaram um comportamento muito semelhante ao trecho de 180 minutos quando o reator foi operado com ciclo de 8 horas. Porém, observou-se que a glicose foi totalmente degradada durante 60 minutos de reação.

As concentrações dos ácidos voláteis totais, observadas na Figura 6.39, atingiram valor máximo $(250 \mathrm{mg} / \mathrm{L})$ aos 75 minutos de reação. Os ácidos presentes foram acético, em maior concentração, butírico e propiônico (Figura 6.40).

A alcalinidade a bicarbonato também teve o mesmo comportamento do perfil obtido para operação com ciclo de 8 horas, até os 170 minutos de operação. A alcalinidade foi consumida durante os primeiros 120 minutos e, em seguida, produzida (Figura 6.41).

Não se observou o mesmo comportamento para o potencial redox e para a fração molar dos gases. Na Figura 6.38, pode-se observar que o valor do potencial redox no início do ciclo foi positivo e começou a ser negativo somente a partir de 45 minutos de reação. $\mathrm{O}$ valor do potencial atingiu valores abaixo de $-200 \mathrm{mV}$, após 100 minutos. Quanto aos gases (Figura 6.42), a fração molar $\mathrm{CH}_{4} / \mathrm{CO}_{2}$ começou com valores menores que 1 e decaiu durante todo o tempo do ciclo atingindo 0,6. Esse comportamento poderia ser resultado do efeito do enchimento e esvaziamento do reator com maior freqüência que na primeira fase, submetendo, em cada operação, os organismos ao contato com oxigênio, interferindo na composição da biomassa. Este fato, no entanto, não se confirmou com as observações microbiológicas, nas quais não se observou frequiência de microrganismos que crescem em condições de microaerofilia, tais como protozoários, sendo comum a presença de fototróficas anoxigênicas nas espumas. É importante ressaltar que as medidas do potencial redox, em 
todas as condições, foram realizadas somente na superfície do reator, e que o potencial redox em outras posições no reator pode apresentar valores diferentes

Nessa condição operacional, com ciclo de 3 horas, observou-se a produção de EPS em quantidades maiores que as observadas quando o reator operou com ciclos de 8 horas em concentrações próximas a $500 \mathrm{mg} / \mathrm{L}$. Ao contrário do que se esperava, a redução do tempo do ciclo, tornou a produção do EPS foi mais rápida do que em tempo de ciclo mais longo. Uma possível explicação para esse resultado foi o aumento da carga aplicada de $1.2 \mathrm{~g} / \mathrm{L}$.dia no caso de ciclo de 8 horas para $3.3 \mathrm{~g} / \mathrm{L}$.dia quando se operou com ciclo de 3 horas. Essa última carga é maior que a obtida para operação com aproximadamente $1000 \mathrm{mg} / \mathrm{L}$ de glicose, com ciclo de 8 horas $(2.1 \mathrm{~kg} / \mathrm{L})$. Talvez a carga aplicada seja o fator principal na formação dos EPS.

Mesmo a hipótese não tendo sido comprovada, o reator ainda foi operado com concentração afluente de glicose próxima a $1000 \mathrm{mg} / \mathrm{L}$.

\subsubsection{Operação com aproximadamente $1000 \mathrm{mg} / \mathrm{L}$ de glicose}

Os valores médios de DQO total $\left(\mathrm{DQO}_{\mathrm{t}}\right)$, DQO filtrada $\left(\mathrm{DQO}_{\mathrm{f}}\right)$, concentrações de glicose $\left(\mathrm{C}_{\mathrm{g}}\right)$, alcalinidade a bicarbonato $(\mathrm{AB})$, ácidos voláteis totais, determinados por cromatografia $\left(\mathrm{AVT}_{\mathrm{c}}\right)$ e por titulometria $\left(\mathrm{AVT}_{\mathrm{t}}\right)$, e $\mathrm{pH}$ no afluente e efluente durante o período de operação com $990 \pm 72 \mathrm{mg} / \mathrm{L}$ de glicose estão apresentados na Tabela 6.5.

Nesta etapa foram observadas maiores diferenças entre $\mathrm{DQO}_{\mathrm{t}}$ e $\mathrm{DQO}_{\mathrm{f}}$ no efluente, indicando arraste de sólidos os do material viscoso, porém não houve dificuldades para filtrar as amostras do efluente. Estas diferenças podem ser observadas na Figura 6.43.

$\mathrm{Na}$ Tabela 6.5 pode-se observar que não se encontrou glicose em amostras do efluente. Os valores médios da alcalinidade a bicarbonato no efluente foram menores que os observados para amostras do afluente. O valor médio da concentração de ácidos voláteis totais foi elevado, explicando, então, o consumo da alcalinidade. 
Tabela 6.5: Médias de DQO, concentrações de glicose, alcalinidade a bicarbonato e ácidos totais $\left(\mathrm{AVT}_{\mathrm{c}}\right.$ e $\left.\mathrm{AVT}_{\mathrm{t}}\right)$ de entrada e saída do ASBBR durante o período de operação com $990 \pm 72 \mathrm{mg} / \mathrm{L}$ de glicose e 3 horas de ciclo.

\begin{tabular}{|c|c|c|c|c|c|c|c|}
\hline & $\begin{array}{l}\mathrm{DQO}_{\mathrm{t}} \\
(\mathrm{mg} / \mathrm{L})\end{array}$ & $\begin{array}{l}\mathrm{DQO}_{\mathrm{f}} \\
(\mathrm{mg} / \mathrm{L})\end{array}$ & $\begin{array}{c}\mathrm{Cg} \\
(\mathrm{mg} / \mathrm{L})\end{array}$ & $\begin{array}{c}\mathrm{AB} \\
\left(\mathrm{mgCaCO}_{3} / \mathrm{L}\right)\end{array}$ & $\begin{array}{l}\mathrm{AVT}_{\mathrm{c}} \\
(\mathrm{mg} / \mathrm{L})\end{array}$ & $\begin{array}{c}\mathrm{AVT}_{\mathrm{t}} \\
(\mathrm{mgHAc} / \mathrm{L})\end{array}$ & pH \\
\hline $\begin{array}{l}\text { Valor Médio no } \\
\text { Afluente }\end{array}$ & $\begin{array}{c}1017 \pm 28 \\
(5)\end{array}$ & $\begin{array}{c}1028 \pm 36 \\
(5)\end{array}$ & $\begin{array}{c}990 \pm 72 \\
(6)\end{array}$ & $\begin{array}{c}495 \pm 40 \\
(6)\end{array}$ & 0 & $\begin{array}{c}34 \pm 9 \\
(6)\end{array}$ & $\begin{array}{c}7,7 \pm 0,3 \\
\text { (6) }\end{array}$ \\
\hline $\begin{array}{l}\text { Valor Médio no } \\
\text { Efluente }\end{array}$ & $\begin{array}{c}534 \pm 94 \\
(5)\end{array}$ & $\begin{array}{c}459 \pm 88 \\
(5)\end{array}$ & 0 & $\begin{array}{c}348 \pm 49 \\
(6)\end{array}$ & $\begin{array}{c}600 \pm 56 \\
(6)\end{array}$ & $\begin{array}{c}184 \pm 16 \\
(6)\end{array}$ & $\begin{array}{c}6,4 \pm 0,1 \\
(6)\end{array}$ \\
\hline
\end{tabular}

( ) número de amostragens.

Nas Figuras 6.43 a 6.47 estão apresentados os valores obtidos dos parâmetros durante a operação do ASBBR com $990 \pm 72 \mathrm{mg} / \mathrm{L}$ de glicose operando com 3 horas de ciclo.

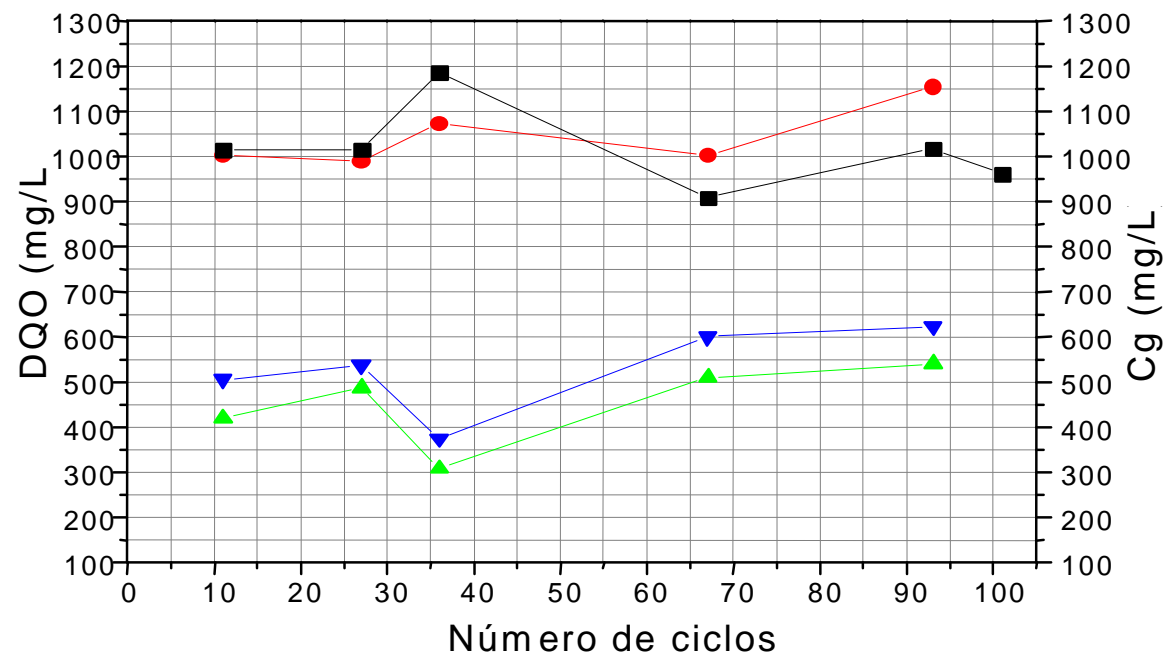

Figura 6.43: Valores da concentração glicose afluente (๘) e DQO filtrada do afluente $(\bullet)$ e efluente $\left({ }^{\bullet}\right)$ e DQO bruta do efluente $\left({ }^{\bullet}\right)$ durante o período de operação do ASBBR alimentado com $990 \pm 72 \mathrm{mg} / \mathrm{L}$ de glicose e 3 horas de ciclo. 


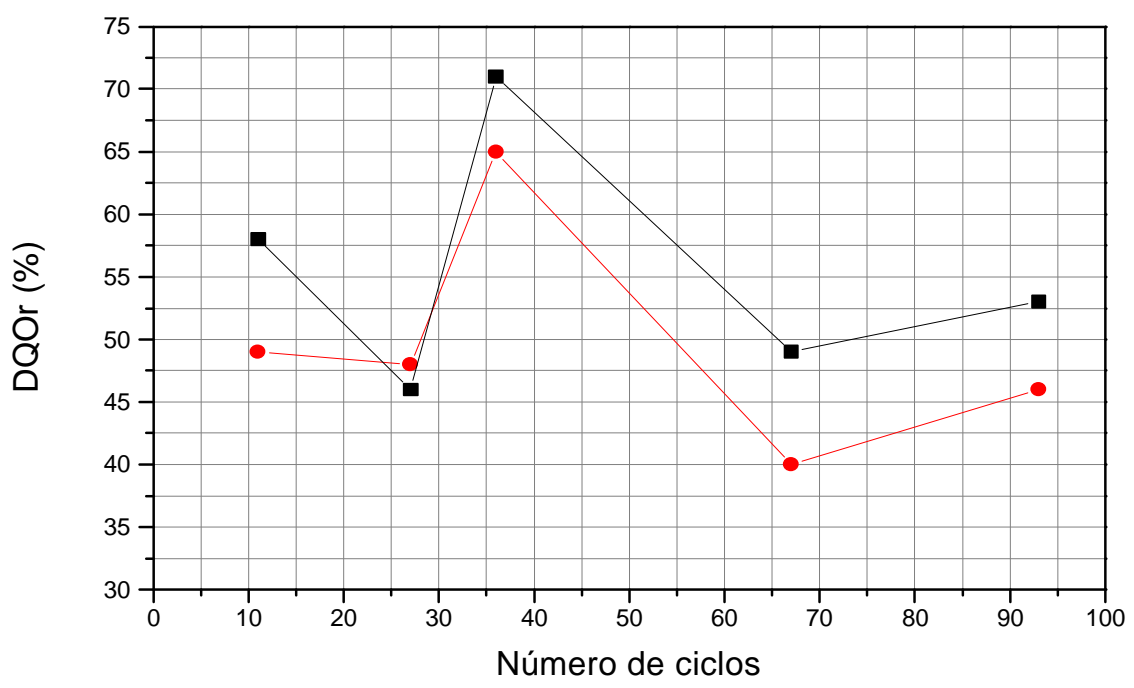

Figura 6.44: Eficiência de redução da DQO bruta $(\bullet)$ e filtrada (•) durante o período de operação do ASBBR alimentado com $990 \pm 72 \mathrm{mg} / \mathrm{L}$ de glicose e 3 horas de ciclo.

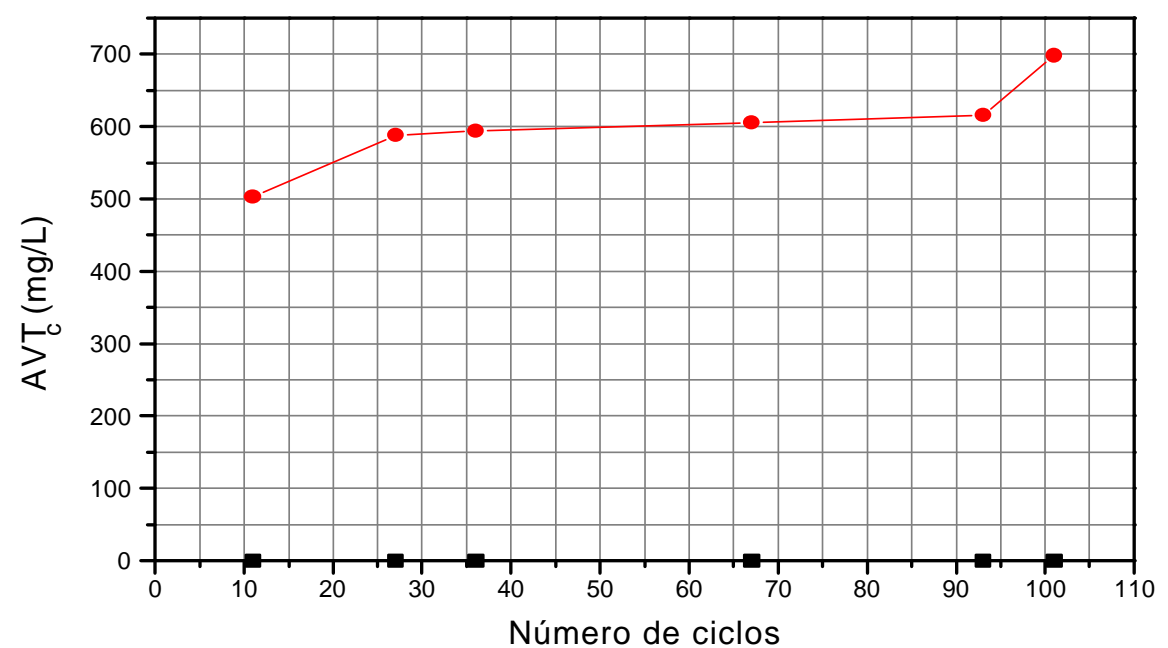

Figura 6.45: Análise da produção de ácidos voláteis totais, obtidos por cromatografia, do afluente $(\bullet)$ e efluente $(\bullet)$ durante o período de operação do ASBBR alimentado com $990 \pm 72 \mathrm{mg} / \mathrm{L}$ de glicose e 3 horas de ciclo. 


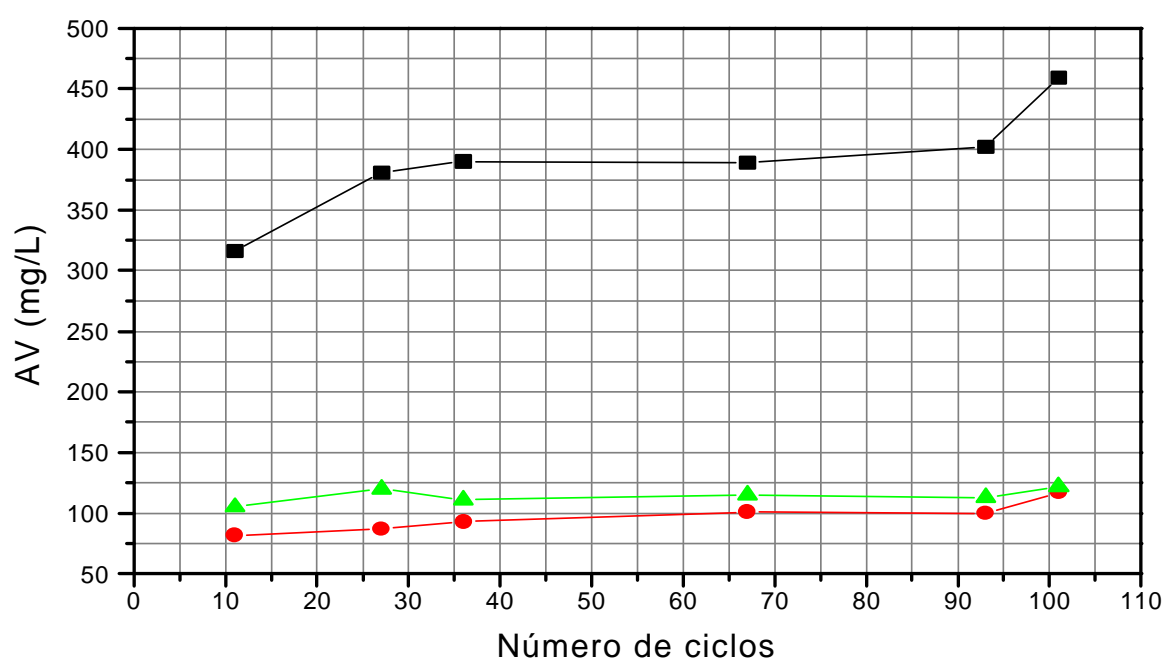

Figura 6.46: Valores da concentração dos ácidos acético (•), propiônico (•) e butírico ( $\left.{ }^{\star}\right)$ obtidos por cromatografia, do efluente durante o período de operação do ASBBR alimentado com $990 \pm 72 \mathrm{mg} / \mathrm{L}$ de glicose e 3 horas de ciclo.

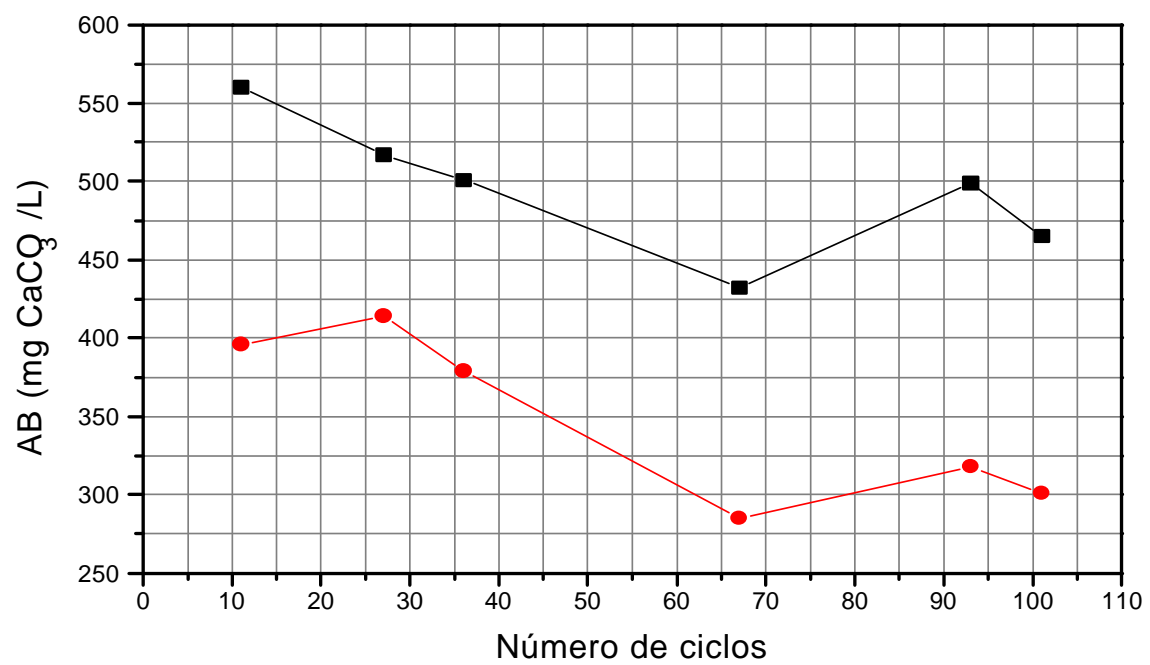

Figura 6.47: Alcalinidade a bicarbonato do afluente $(\boldsymbol{\bullet})$ e efluente $(\bullet)$ durante o período de operação do ASBBR alimentado com $990 \pm 72 \mathrm{mg} / \mathrm{L}$ de glicose e 3 horas de ciclo.

A eficiência de remoção da DQO (Figura 6.44) manteve-se numa média de $50 \%$, para DQO total, e 55\% para DQO filtrada.

As concentrações dos ácidos voláteis totais, obtidos por cromatografia, na maioria dos ciclos, mantiveram-se em torno de $600 \mathrm{mg} / \mathrm{L}$. Com 3 horas de ciclo a produção de ácidos 
foi aproximadamente três vezes maior que com 8 horas de ciclo. Isto pode ser observado comparando-se a Figura 6.45 com a Figura 6.22, cuja produção máxima dos ácidos, com 3 horas de operação foi de $180 \mathrm{mg} / \mathrm{L}$. Talvez esta maior concentração de ácido, quando o reator está operando com 3 horas de ciclo, seja devido ao EPS, que já estava presente em todo o reator.

Os ácidos produzidos foram acético, em torno de $400 \mathrm{mg} / \mathrm{L}$, butírico e propiônico, em torno de $100 \mathrm{mg} / \mathrm{L}$ cada (Figura 6.46). A alcalinidade a bicarbonato no efluente, durante o período de operação, sempre foi menor que no afluente (Figura 6.47).

O reator não operou de maneira estável, nessas condições, pois se observou um maior acúmulo de ácidos e consumo da alcalinidade a bicarbonato e variações na remoção de DQO. A massa total de polímero obtida durante a operação do reator com 3 horas de ciclo foi de $4,8 \mathrm{~g}$ de SVT.

A operação do reator com ciclo de 3 horas indicou que, nesse caso, a produção de material semelhante a EPS não teve como motivo a exposição da biomassa por longo tempo as baixas concentrações de matéria orgânica, conforme postulado. Na operação com 3 horas de ciclo tal fato não ocorreu, mas a produção de polímero foi igual ou superior ao observado para a operação com tempo de ciclo de 8 horas. Tal material pode ter se formado como resultado da exposição dos microrganismos a altas concentrações de ácidos, primeira hipótese levantada e sustentada por CHRYSI \& BRUCE (2002), ou como consequiência do aumento da carga orgânica aplicada ao sistema (Tabela 5.1).

A quantidade de biomassa encontrada nas espumas, tratando $495 \mathrm{mg} / \mathrm{L}$ e 990 de glicose, foi de 12,4 g SVT/L e 15,2 g SVT/L, respectivamente.

\subsection{Estudos Cinéticos}

A partir das curvas obtidas nos perfis temporais da DQO e da concentração de glicose foram realizados estudos cinéticos.

O modelo ajustado aos pontos dos perfis de concentração de glicose foi o modelo de primeira ordem, enquanto que o modelo modificado (eq. 3.1), com concentração residual, foi ajustado aos perfis temporais de DQO.

Os dados experimentais estão apresentados nas Figuras 6.48 e 6.49 e os parâmetros cinéticos aparentes de primeira ordem, a concentração inicial de substrato $\left(\mathrm{C}_{\mathrm{S} 0}\right)$ e concentração residual de substrato $\left(\mathrm{C}_{\mathrm{SR}}\right)$, para cada condição estão apresentados nas Tabelas 6.6 a 6.8 .

Na Figura 6.48 pode-se observar que as curvas de decaimento da DQO ao longo das 
8 horas da batelada, nas concentrações de $509 \mathrm{mg} / \mathrm{L}$ e $991 \mathrm{mg} / \mathrm{L}$, apresentam dois trechos com comportamento bem definido de primeira ordem. Dessa forma, para o caso da DQO, foram ajustados os parâmetros para o primeiro e para o segundo trecho separadamente.

Tabela 6.6: Parâmetros cinéticos obtidos com o ajuste cinético de primeira ordem com concentração de $541 \mathrm{mg} / \mathrm{L}$ de glicose e 8 horas de ciclo.

\section{Ciclo de 8 horas}

Concentração de glicose afluente $541 \mathrm{mg} / \mathrm{L}$

\begin{tabular}{lccc} 
& Glicose & DQO $\left(\mathbf{1}^{\mathbf{o}}\right.$ trecho $)$ & DQO $\left(\mathbf{2}^{\mathbf{o}}\right.$ trecho $)$ \\
\hline $\mathbf{k}_{\mathbf{1}}{ }^{\text {app }}\left(\mathbf{m i n}^{-\mathbf{1}}\right)$ & $0,05251 \pm 0,00361$ & $0,05359 \pm 0,00749$ & $0,0142 \pm 0,00196$ \\
$\mathbf{C}_{\mathbf{S} \mathbf{0}}(\mathbf{m g} / \mathbf{L})$ & 531 & 509 & 110 \\
$\mathbf{C}_{\mathbf{S R}}(\mathbf{m g} / \mathbf{L})$ & - & $161 \pm 11$ & $27 \pm 4$ \\
$\mathbf{R}^{2}$ & 0,9884 & 0,97521 & 0,97803 \\
\hline
\end{tabular}

Tabela 6.7: Parâmetros cinéticos obtidos com o ajuste cinético de primeira ordem com concentração de $942 \mathrm{mg} / \mathrm{L}$ de glicose e 8 horas de ciclo.

\begin{tabular}{lccc}
\hline \multicolumn{3}{c}{ Ciclos de 8 horas } \\
\hline \multicolumn{4}{c}{ Concentração de glicose afluente 942 $\mathbf{~ m g} / \mathbf{L}$} \\
& Glicose & DQO $\left(\mathbf{1}^{\mathbf{0}}\right.$ trecho $)$ & $\mathbf{D Q O}\left(\mathbf{2}^{\mathbf{0}}\right.$ trecho $)$ \\
\hline $\mathbf{k}_{\mathbf{1}}{ }^{\text {app }}\left(\mathbf{m i n}^{-\mathbf{1}}\right)$ & $0,06497 \pm 0,00252$ & $0,06256 \pm 0,00824$ & $0,00595 \pm 0,0017$ \\
$\mathbf{C}_{\mathbf{S} \mathbf{0}}(\mathbf{m g} / \mathbf{L})$ & 942 & 991 & 228 \\
$\mathbf{C}_{\mathbf{S R}}(\mathbf{m g} / \mathbf{L})$ & - & $265 \pm 24$ & $93 \pm 22$ \\
$\mathbf{R}^{\mathbf{2}}$ & 0,99748 & 0,9889 & 0,965 \\
\hline
\end{tabular}

Tabela 6.8: Parâmetros cinéticos obtidos com o ajuste cinético de primeira ordem com concentração de $493 \mathrm{mg} / \mathrm{L}$ de glicose e 3 horas de ciclo.

\begin{tabular}{lcc}
\hline & \multicolumn{2}{c}{ Ciclos de 3 horas } \\
\hline & Concentração de glicose afluente $\mathbf{5 0 0} \mathbf{~ m g / L}$ \\
& Glicose & DQO \\
\hline $\mathbf{k}_{\mathbf{1}}{ }^{\text {app }}\left(\mathbf{m i n}^{-1}\right)$ & $0,05129 \pm 0,00314$ & $0,06271 \pm 0,00239$ \\
$\mathbf{C}_{\mathbf{S} \mathbf{0}}(\mathbf{m g} / \mathbf{L})$ & 493 & 532 \\
$\mathbf{C}_{\mathbf{S R}}(\mathbf{m g} / \mathbf{L})$ & - & $139 \pm 2$ \\
$\mathbf{R}^{\mathbf{2}}$ & 0,99237 & 0,99708 \\
\hline
\end{tabular}


Glicose $(531 \mathrm{mg} / \mathrm{L})$

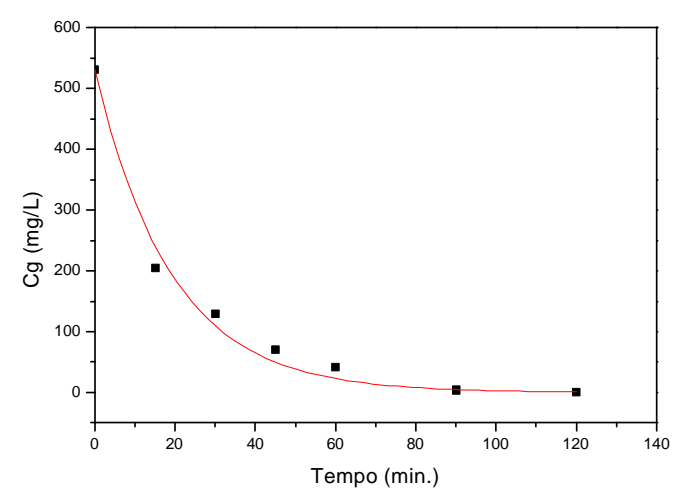

DQO - $509 \mathrm{mg} / \mathrm{L}\left(1^{\circ}\right.$ trecho $)$

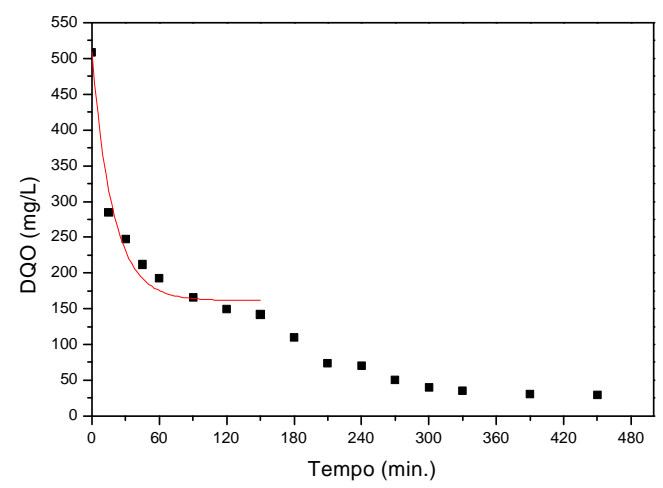

DQO - $509 \mathrm{mg} / \mathrm{L}\left(2^{\circ}\right.$ trecho $)$

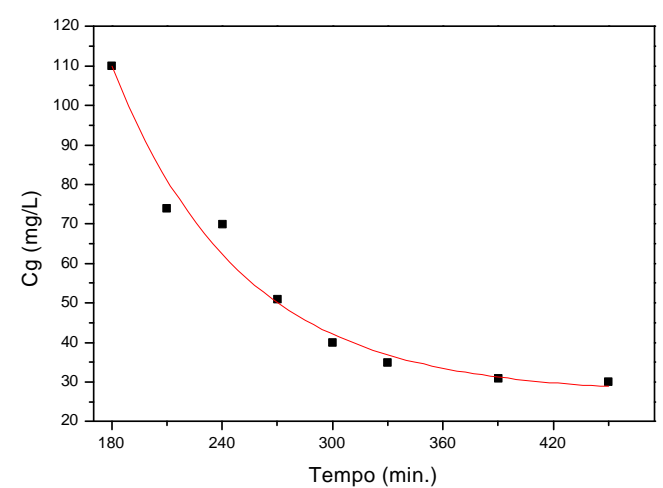

Glicose $(942 \mathrm{mg} / \mathrm{L})$

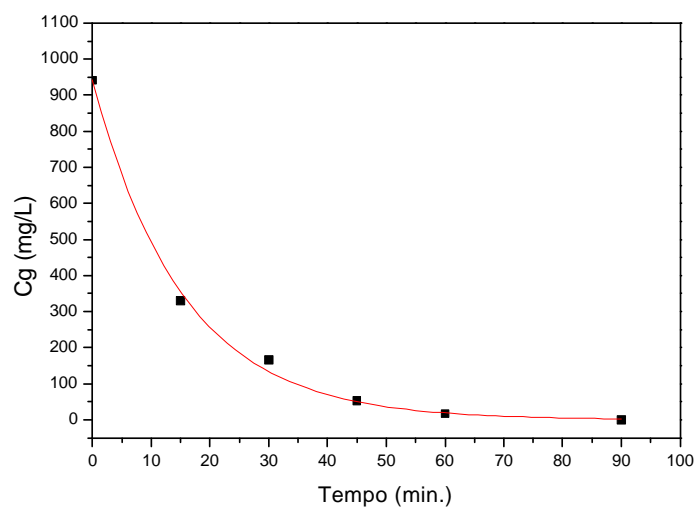

$\mathrm{DQO}-991 \mathrm{mg} / \mathrm{L}\left(1^{\circ}\right.$ trecho $)$

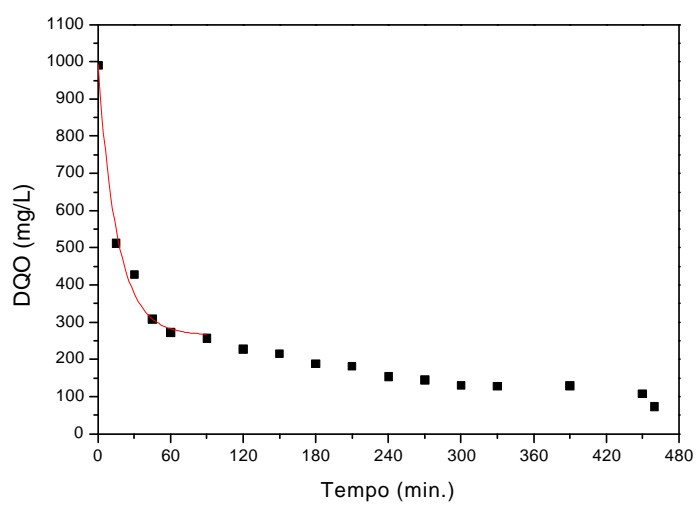

DQO - $991 \mathrm{mg} / \mathrm{L}\left(2^{\circ}\right.$ trecho $)$

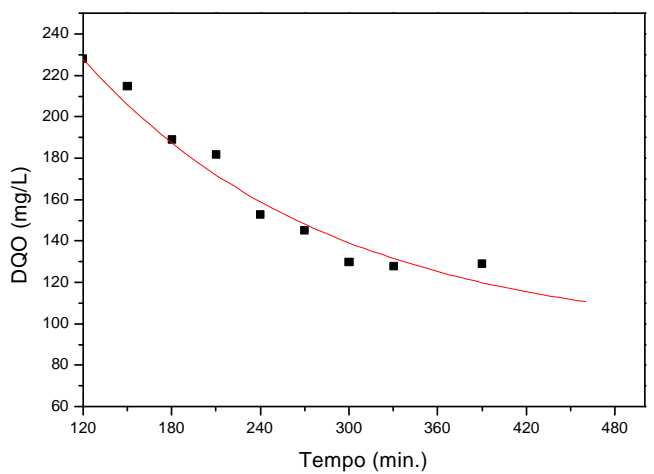

Figura 6.48: Modelo cinético de primeira ordem ajustado aos dados experimentais de consumo de glicose e de decaimento de DQO ao longo do tempo com ciclo de 8 horas. 
Nas Tabelas 6.6 e 6.7 observa-se que o valor da constante cinética aparente de primeira ordem obtida para consumo de glicose tem praticamente o mesmo valor da constante obtida no primeiro trecho para o decaimento da DQO. Dessa forma, podese concluir que o $1^{\circ}$ trecho corresponde ao consumo da glicose e o $2^{\circ}$ trecho corresponde ao consumo dos produtos intermediários, formados durante a degradação da glicose, ou seja, os intermediários começam a ser consumidos somente após a degradação total da glicose.

O valor da constate cinética, obtido no segundo trecho do decaimento da DQO foi bem menor que o obtido no $1^{\circ}$ trecho (Tabelas 6.6 e 6.7), ou seja, o consumo dos intermediários é muito mais lento que o consumo da glicose. No entanto, para a menor concentração de glicose $(531 \mathrm{mg} / \mathrm{L})$ a constante para degradação dos produtos intermediários foi quase quatro vezes menor que a constante de degradação da glicose, enquanto que, para a concentração mais alta de glicose $(942 \mathrm{mg} / \mathrm{L})$ a constante de degradação de intermediários foi dez vezes menor que o da glicose. $\mathrm{O}$ valor bem menor no segundo caso vem reforçar a hipótese de limitação à transferência de massa quando há grande formação do material polimérico. Deve-se ressaltar que, para a operação com tempo de ciclo de 8 horas, só foi observada alta produção de material polimérico quando a concentração de glicose foi de aproximadamente $1000 \mathrm{mg} / \mathrm{L}$.

Glicose $(493 \mathrm{mg} / \mathrm{L})$

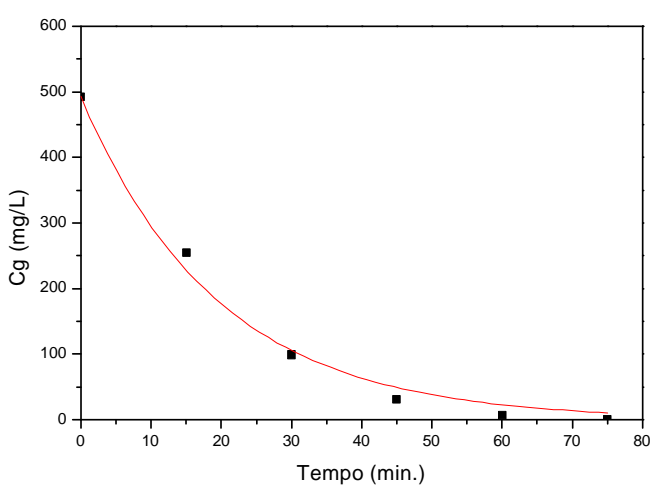

DQO $(532 \mathrm{mg} / \mathrm{L})$

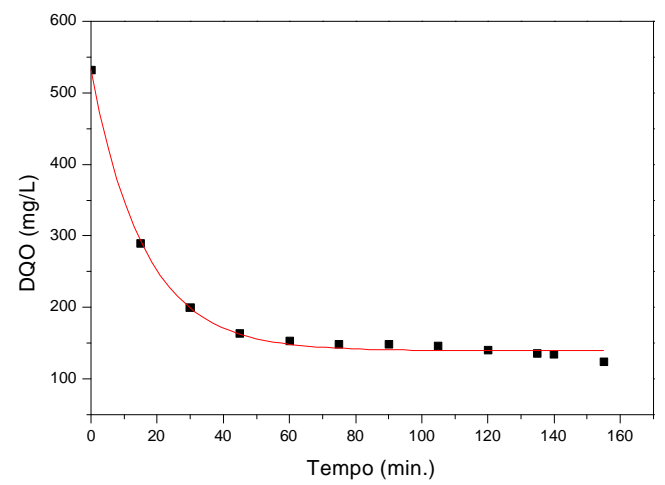

Figura 6.49: Modelo cinético de primeira ordem ajustado aos dados experimentais de consumo de glicose e de decaimento de DQO ao longo do tempo com ciclo de 3 horas.

Os ajustes cinéticos das curvas de decaimento da DQO e da concentração de glicose, com 3 horas de ciclo estão apresentados na Figura 6.49. Nesse caso, não se observa um ajuste cinético em dois trechos de decaimento da DQO com 3 horas de ciclos, pois neste intervalo de tempo ocorreu somente a degradação da glicose. 
Os valores de $k_{1}{ }^{\text {app }}$ da degradação de glicose nos três casos foram praticamente iguais, ou seja, a degradação da glicose no ASBBR teve o mesmo comportamento em termos cinéticos, independente o tempo de ciclo e da concentração de glicose.

O valor da constante cinética para degradação da glicose, utilizada por BAGLEY \& BRODKORB (1999), foi de $13,9 \cdot 10^{-6} \mathrm{~min}^{-1}\left(0,02 \mathrm{dia}^{-1}\right)$. Portanto, a degradação da glicose no ASBR foi muito lenta comparada com o ASBBR. Isso pode ser resultado, entre outros fatores, da utilização da espuma de poliuretano como suporte de imobilização, o que pode facilitar a transferência do substrato para as populações microbianas, ao contrário do grânulo que é compacto, podendo limitar essa transferência de substrato. 


\subsection{Exames Microbiológicos}

Foram realizados exames microbiológicos de alguns cubos de espuma e do polímero extracelular ao final de cada operação.

As amostras de EPS eram retiradas da superfície do cesto de inox (SC) e das pás de agitação, superior (PS) e inferior (PI).

Nas análises microscópicas realizadas após operar o reator com concentração de glicose afluente de $500 \mathrm{mg} / \mathrm{L}$, aproximadamente, e ciclo de 8 horas observou-se que a biomassa da espuma e do ESP era composta basicamente por bacilos de dimensões variadas, víbrios, cocos ovalados, estruturas semelhantes a cistos de protozoários e por filamentos delgados que possivelmente são acidogênicos.

Nas análises microscópicas das espumas, depois do reator operar com aproximadamente $1000 \mathrm{mg} / \mathrm{L}$ de glicose no afluente e 8 horas de ciclo, observou-se a presença de bacilos de dimensões variadas, bacilos fluorescentes, agrupamento de cocos, Metanossarcina e filamentos com inclusões. No material viscoso presente na superfície do cesto havia hifas de fungos, protozoários, filamentos septados, espirilos, além dos microrganismos encontrados nas espumas. Comparando-se com a população microbiana da primeira condição, no ASBBR operado com aproximadamente $1000 \mathrm{mg} / \mathrm{L}$ de glicose, foi observada uma maior variedade de microrganismos. Os microrganismos que apresentaram coloração Gram (-) foram predominantes na espuma, enquanto que no EPS foram observadas proporções aparentemente iguais entre Gram (+) e (-).

No final da operação com aproximadamente 500 e 1000 mg/L, com 3 horas de ciclo, a população microbiana na espuma e no EPS foi semelhante à população quando o reator operou com 8 horas de ciclo, porém em quantidades maiores. Os microrganismos das espumas e do EPS apresentaram proporções iguais entre Gram (+) e (-).

Os microrganismos encontrados nos materiais analisados estão apresentados, em escala quantitativa, nas Tabelas 6.9 e 6.10 .

Algumas morfologias observadas na microscopia de contraste de fase e epifluorescência e a coloração Gram estão apresentadas nas Figuras 6.50 a 6.56 . 
Tabela 6.10: Diversidade microbiana das amostras de espuma, dos polímeros extracelular retirados na superfície do cesto (SC), dos impelidores que ficam na parte superior (IS) e no fundo do reator (IF), após operação do ASBBR com ciclos de 3 horas.

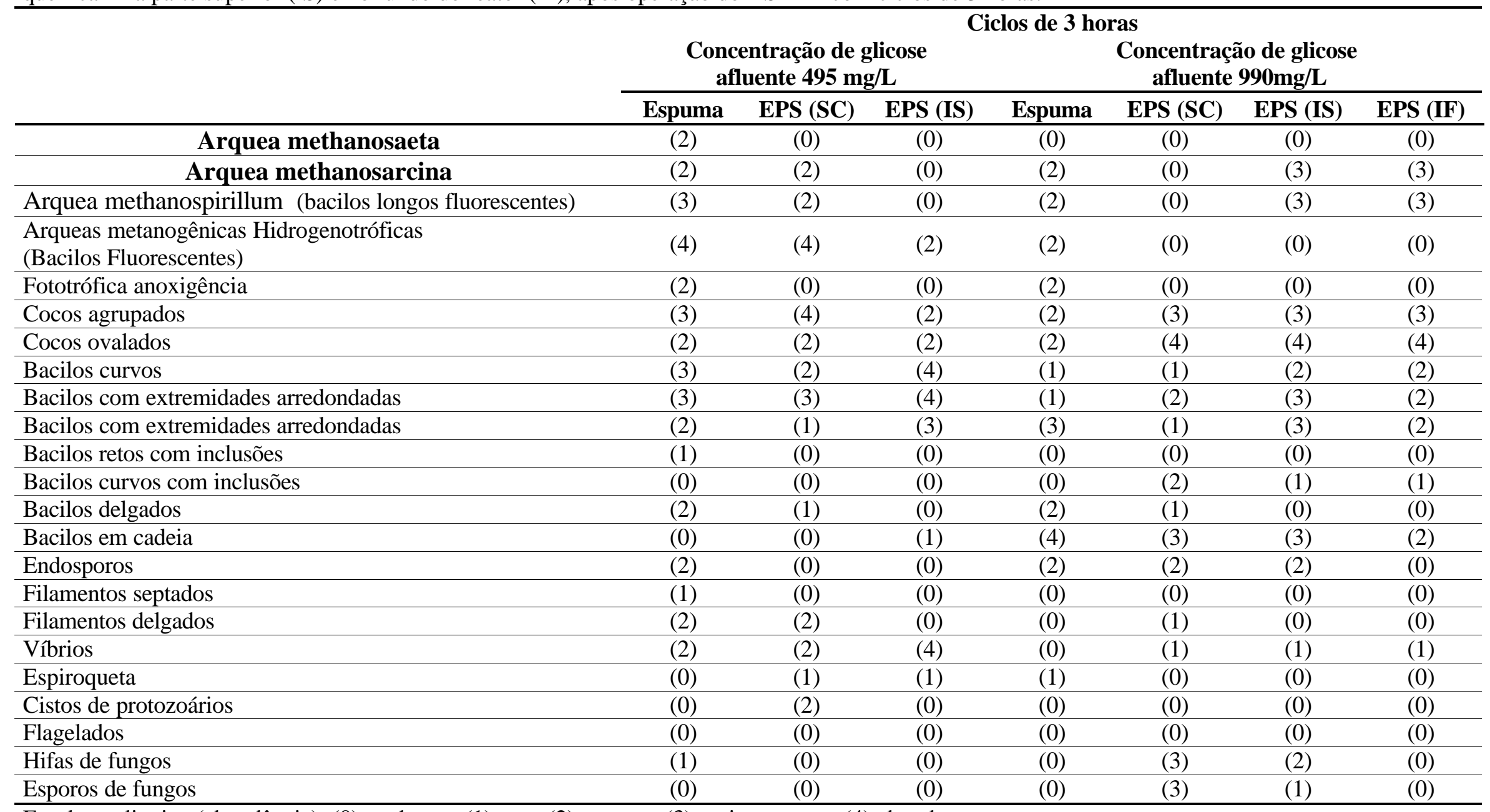

Escala qualitativa (abundância): (0) nenhuma; (1) rara; (2) comum; (3) muito comum; (4) abundante 
Tabela 6.9: Diversidade microbiana das amostras de espuma, dos polímeros extracelular retirados na superfície do cesto (SC), dos impelidores que ficam na parte superior (IS) e no fundo do reator (IF), após operação do ASBBR com ciclos de 8 horas.

\section{Ciclos de 8 horas}

Concentração de glicose afluente $470 \mathrm{mg} / \mathrm{L}$ Concentração de glicose afluente $852 \mathrm{mg} / \mathrm{L}$

\begin{tabular}{|c|c|c|c|c|c|c|c|c|}
\hline & \multicolumn{4}{|c|}{ Concentração de glicose afluente $470 \mathrm{mg} / \mathrm{L}$} & \multicolumn{4}{|c|}{ Concentração de glicose afluente $852 \mathrm{mg} / \mathrm{L}$} \\
\hline & Espuma & EPS (SC) & EPS (IS) & EPS (IF) & Espuma & EPS (SC) & EPS (IS) & EPS (IF) \\
\hline Arquea methanosaeta & $(0)$ & $(0)$ & $(0)$ & $(0)$ & $(0)$ & $(2)$ & $(2)$ & $(0)$ \\
\hline Arquea methanosarcina & (2) & $(0)$ & $(0)$ & (1) & (3) & $(0)$ & (2) & $(0)$ \\
\hline $\begin{array}{l}\text { Arquea Methanospirillum } \\
\text { (bacilos longos fluorescentes) }\end{array}$ & $(0)$ & $(0)$ & $(0)$ & $(0)$ & $(0)$ & $(0)$ & $(0)$ & $(0)$ \\
\hline $\begin{array}{l}\text { Arqueas metanogênicas Hidrogenotróficas } \\
\text { (Bacilos Fluorescentes) }\end{array}$ & $(0)$ & $(0)$ & $(0)$ & $(0)$ & (3) & (3) & $(2)$ & $(2)$ \\
\hline Fototrófica anoxigência & $(0)$ & $(0)$ & $(0)$ & $(0)$ & (3) & (3) & $(2)$ & $(0)$ \\
\hline Cocos agrupados & $(0)$ & $(0)$ & $(0)$ & (2) & (1) & (2) & (2) & (2) \\
\hline Cocos ovalados & (3) & (4) & (3) & (3) & $(2)$ & $(2)$ & (3) & $(2)$ \\
\hline Bacilos curvos & (1) & (4) & (1) & $(2)$ & (1) & (3) & $(2)$ & $(2)$ \\
\hline Bacilos com extremidades arredondadas & (3) & (3) & $(3)$ & $(4)$ & $(4)$ & (3) & $(2)$ & $(2)$ \\
\hline Bacilos retos com inclusões & $(1)$ & $(0)$ & $(1)$ & $(2)$ & $(0)$ & $(2)$ & $(0)$ & $(0)$ \\
\hline Bacilos curvos com inclusões & $(0)$ & $(0)$ & $(0)$ & $(0)$ & $(2)$ & (2) & $(0)$ & $(0)$ \\
\hline Bacilos delgados & $(0)$ & $(0)$ & $(0)$ & $(2)$ & $(0)$ & (2) & $(2)$ & $(0)$ \\
\hline Bacilos em cadeia & $(1)$ & $(0)$ & $(1)$ & $(0)$ & $(4)$ & $(4)$ & (3) & $(2)$ \\
\hline Endosporos & $(0)$ & $(0)$ & $(0)$ & $(0)$ & $(0)$ & $(0)$ & $(0)$ & $(0)$ \\
\hline Filamentos septados & $(0)$ & $(0)$ & $(0)$ & $(1)$ & $(0)$ & $(2)$ & $(2)$ & $(2)$ \\
\hline Filamentos delgados & $(0)$ & $(0)$ & $(2)$ & $(2)$ & $(2)$ & $(0)$ & $(2)$ & $(1)$ \\
\hline Víbrios & $(2)$ & $(0)$ & $(0)$ & $(0)$ & $(1)$ & $(2)$ & $(1)$ & $(2)$ \\
\hline Espiroqueta & $(0)$ & (1) & $(0)$ & (1) & $(0)$ & (1) & $(0)$ & (1) \\
\hline Cistos de protozoários & $(2)$ & (4) & $(0)$ & $(2)$ & $(0)$ & (3) & $(0)$ & $(0)$ \\
\hline Flagelados & $(0)$ & $(1)$ & $(0)$ & $(0)$ & $(0)$ & $(2)$ & $(0)$ & $(0)$ \\
\hline Hifas de fungos & $(0)$ & $(0)$ & $(0)$ & $(0)$ & $(0)$ & (2) & $(0)$ & $(0)$ \\
\hline Esporos de fungos & $(0)$ & $(0)$ & $(0)$ & $(0)$ & $(0)$ & $(0)$ & $(0)$ & $(0)$ \\
\hline
\end{tabular}

Escala qualitativa (abundância): (0) nenhuma; (1) rara; (2) comum; (3) muito comum; (4) abundante 


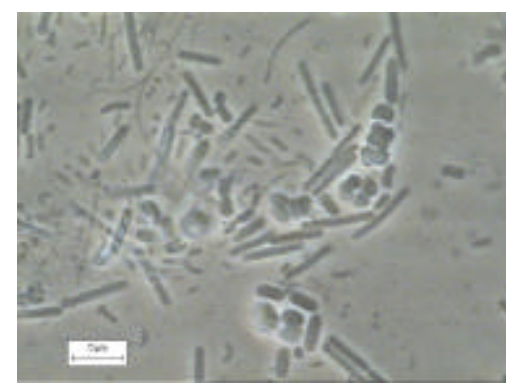

(a)

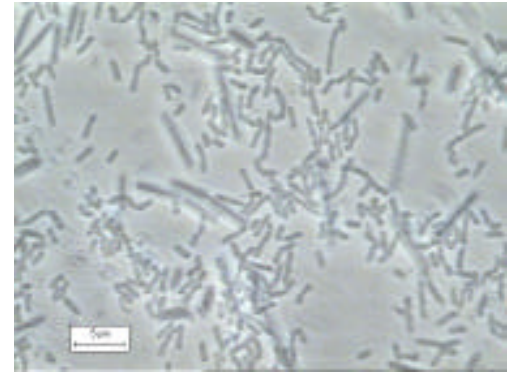

(c)

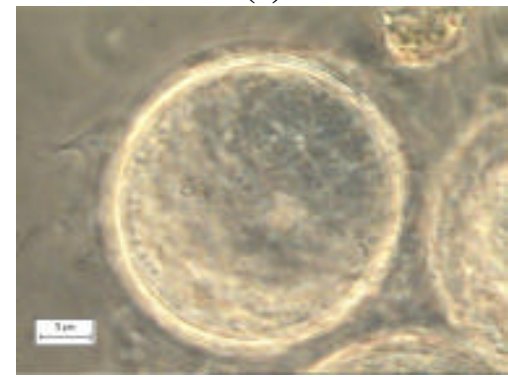

(e)

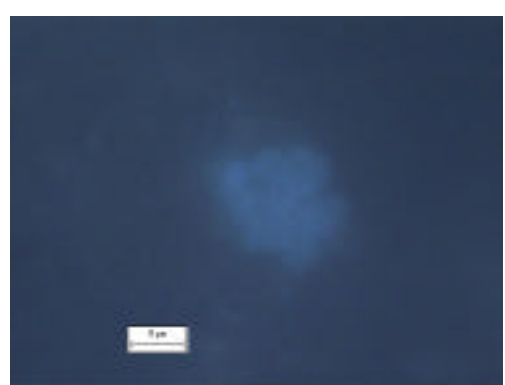

(b)

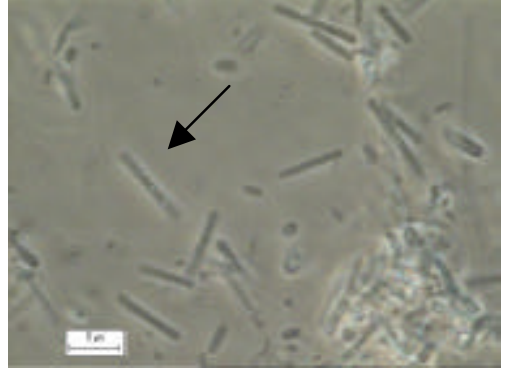

(d)

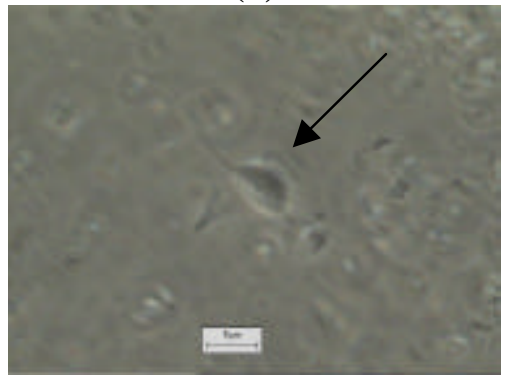

(f)

Figura 6.50: Observações morfológicas sob microscopia de contraste de fase e epifluorescência, referentes à̀ amostras do reator ao final da operação com $470 \mathrm{mg} / \mathrm{L}$ de glicose e 8 horas de ciclo: (a) filamentos e bacilos delgados,bacilos retos com inclusões e morfologias semelhantes a Methanosarcinas; (b) morfologia semelhante a Methanosarcina; (c) bacilos de dimensões variadas e cocos ovalados; (d) bacilo reto com inclusões; (e) estruturas semelhantes a cistos de protozoários; (f). protozoário flagelado 


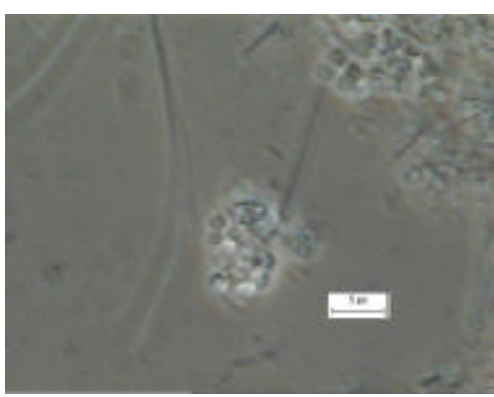

(a)

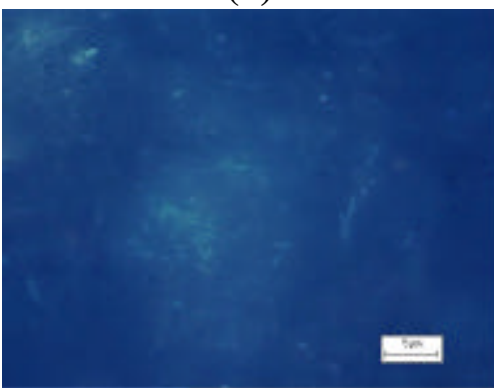

(d)

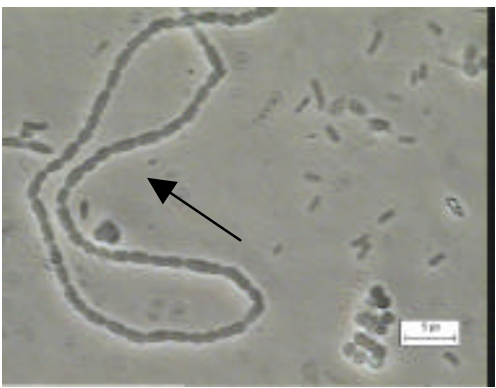

(g)

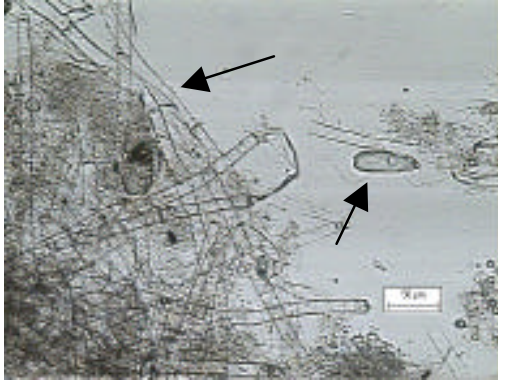

(j)

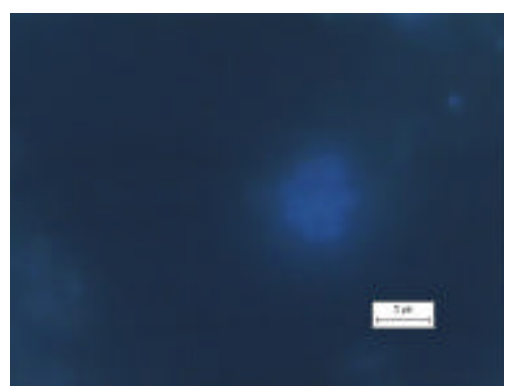

(b)

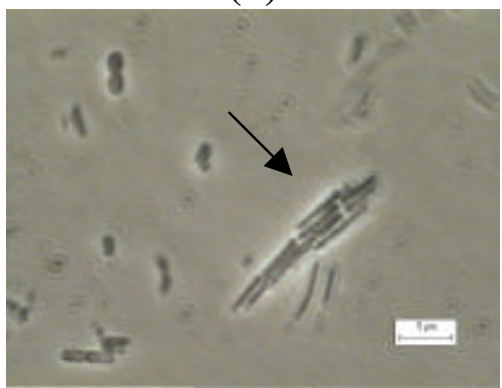

(e)

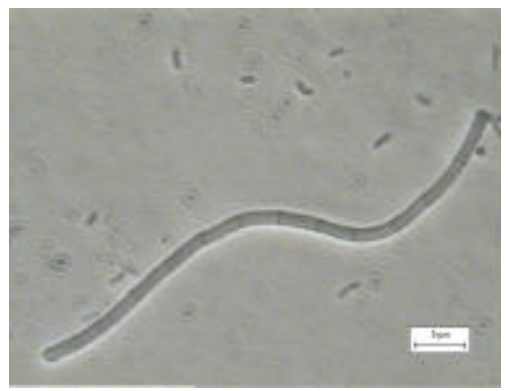

(h)

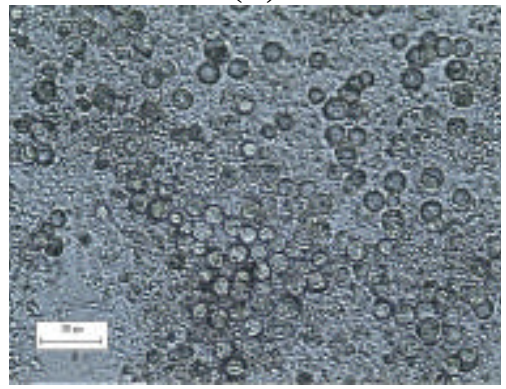

(I)

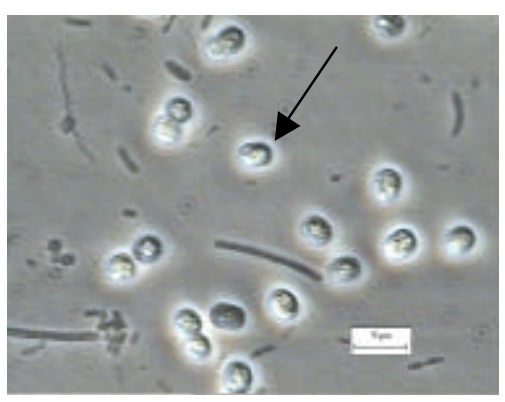

(c)

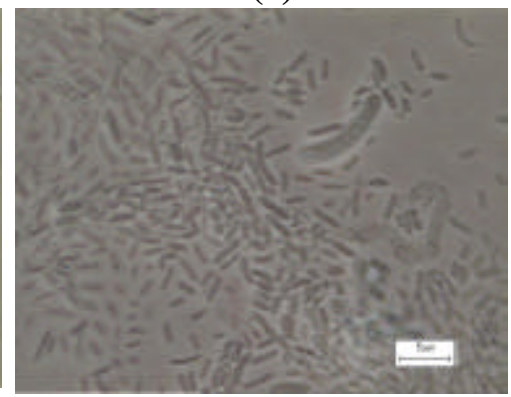

(f)

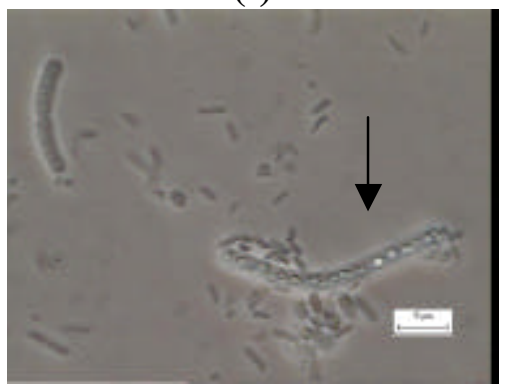

(i)

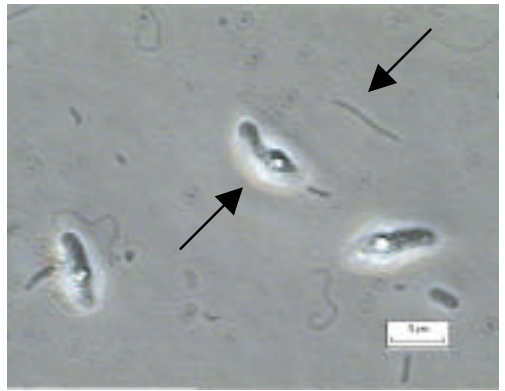

(m)

Figura 6.51.: Observações morfológicas sob microscopia de contraste de fase e epifluorescência, referentes à amostras do reator ao final da operação com $852 \mathrm{mg} / \mathrm{L}$ de glicose e 8 horas de ciclo: (a) e (b) morfologias semelhantes a Methanosarcinas, (c) estruturas semelhantes as bactérias fototróficas anoxigênicas; (d) bacilos fluorescentes; (e) morfologia semelhante a Methanosaeta (f) bacilos de dimensões variadas; (g) filamento de bacilos; (h) filamento septado; (i) bacilo curvo com inclusões; (j) estruturas semelhantes a hifas de fungos e esporos de fungos; (l) estruturas semelhantes a cistos de protozoários; (m) espiroquetas e protozoários flagelados. 

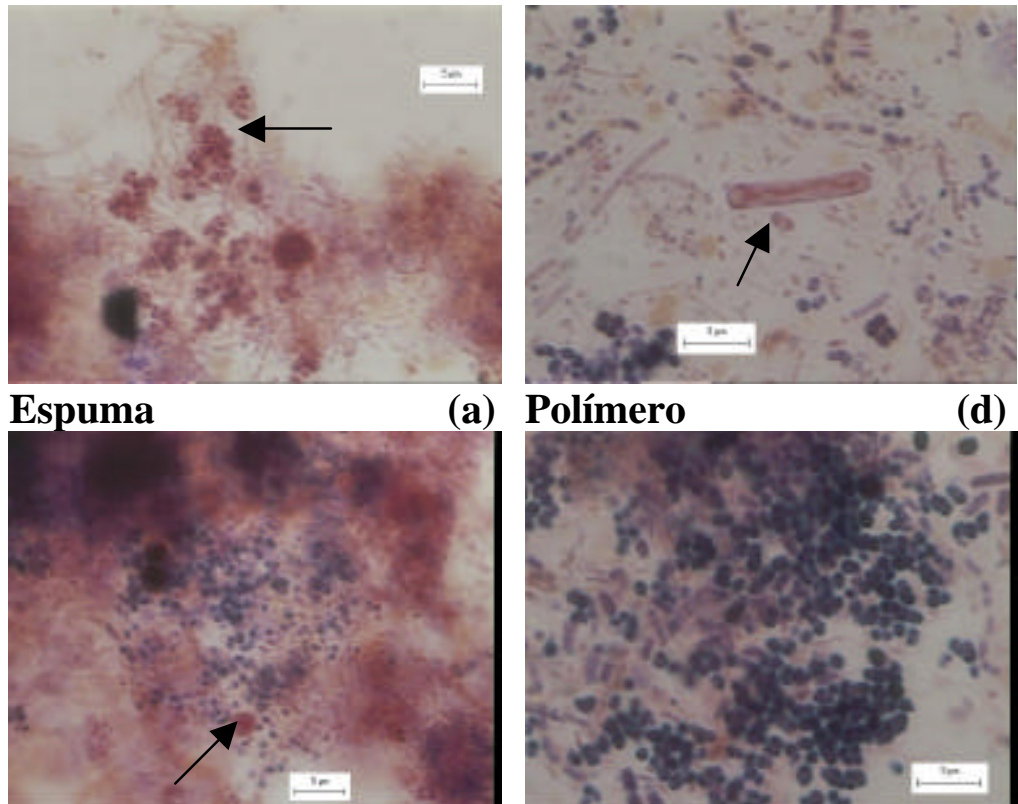

Espuma

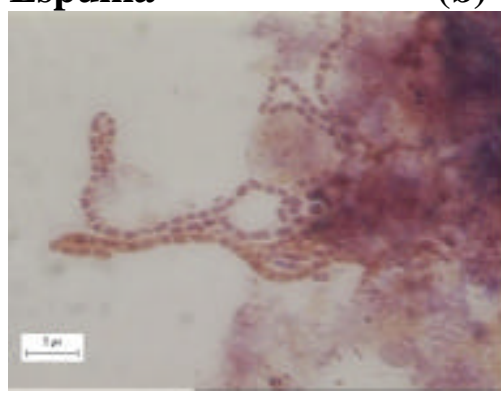

Espuma (b) Polímero

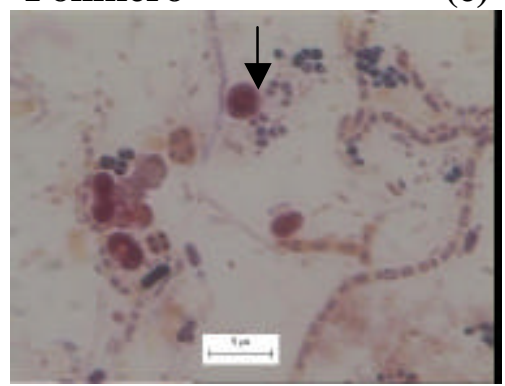

(c) Polímero d)

Figura 6.52: Observações da coloração Gram nas morfológicas, obtidas por microscopia de contraste de fase, referentes à amostras do reator ao final da operação com $852 \mathrm{mg} / \mathrm{L}$ de glicose e 8 horas de ciclo: (a) estruturas semelhantes a Methanosarcinas, apresentando coloração Gram (-); (b) cocos com coloração Gram (+) estruturas semelhantes a bactérias fototróficas anoxigências apresentando coloração Gram (-); (c) estruturas semelhantes ao filamento de bacilos apresentando coloração Gram (-); (d) Bacilo reto com inclusão Gram (-); (e) cocos Gram (+); (f) estruturas semelhantes a bactérias fototróficas anoxigênicas apresentando coloração Gram (-). 


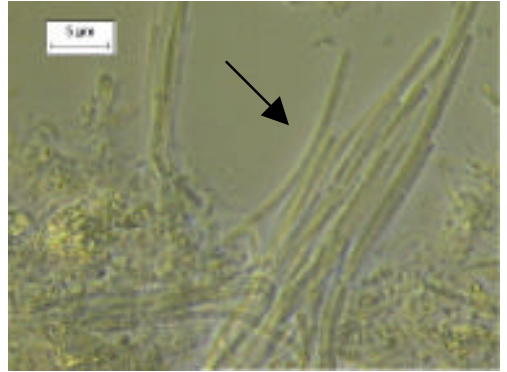

(a)

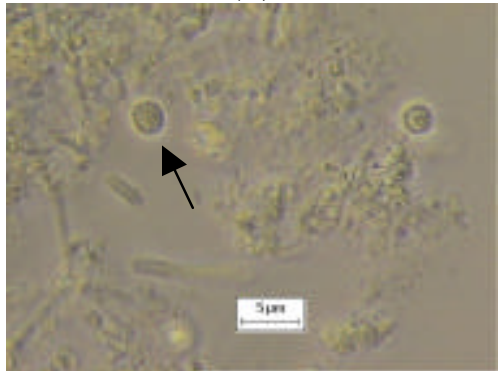

(d)

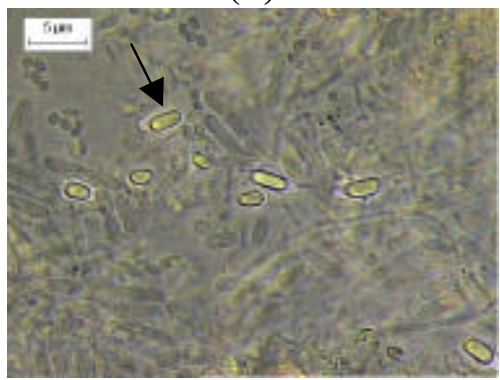

(g)

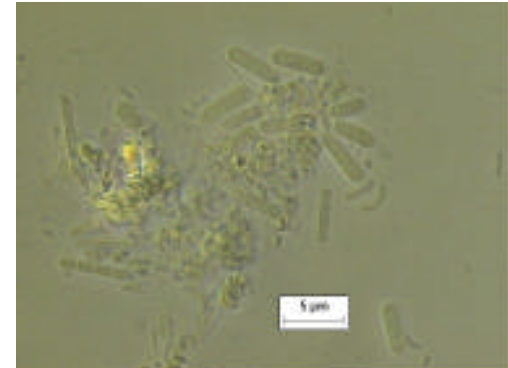

(b)

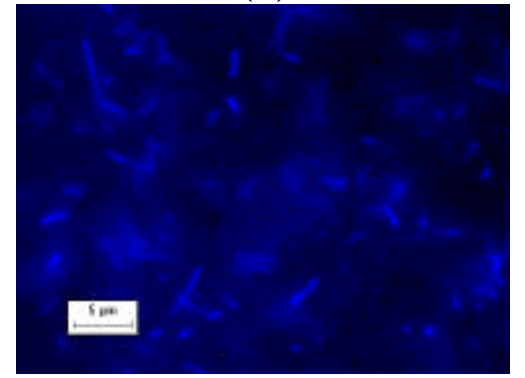

(e)

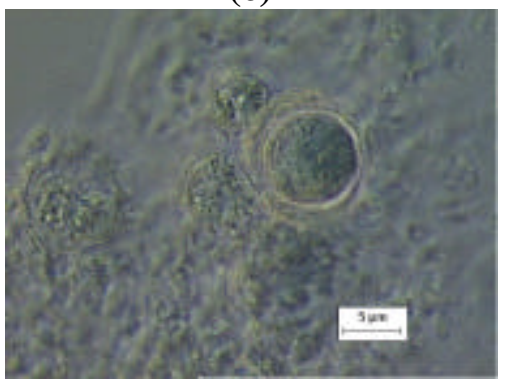

(h)

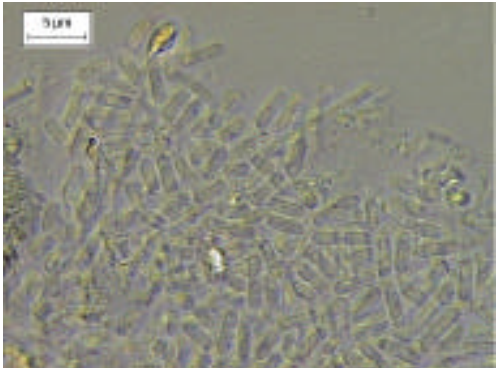

(c)

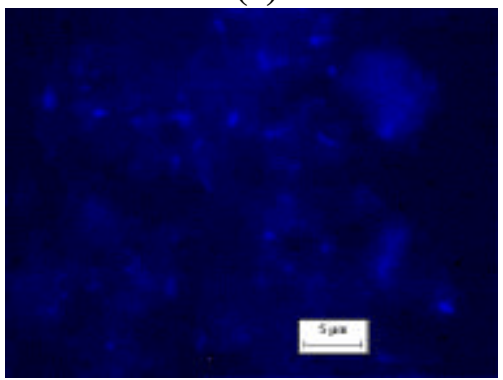

(f)

Figura 6.53: Observações morfológicas sob microscopia de contraste de fase e epifluorescência, referentes æ̀̀ amostras do reator ao final da operação com $495 \mathrm{mg} / \mathrm{L}$ de glicose e 3 horas de ciclo: (a) estruturas semelhantes a Methanosaetas, (b) bacilos de dimensões variadas; (c) bacilos com extremidades arredondadas; (d) estruturas semelhantes a bactérias fototróficas anoxigênicas; (e) bacilos fluorescentes com morfologia semelhante a Arquea methanospirillum, (f) bacilos fluorescentes com morfologia semelhante a arqueas metanogênicas hidrogênotróficas; ( $g$ ) estruturas semelhantes a endosporos; (h) estruturas semelhantes a cistos de protozoários. 

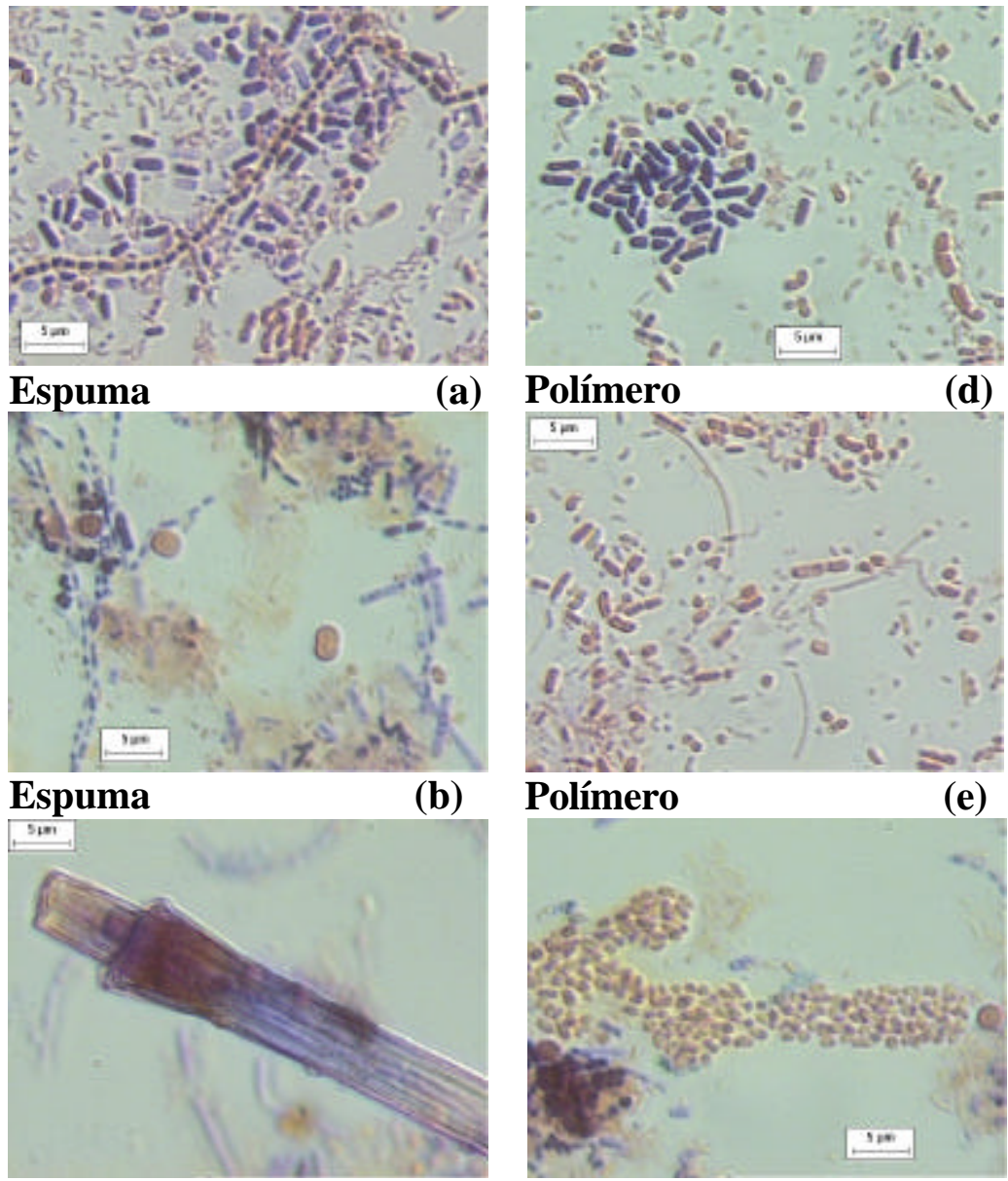

Espuma

(c) Polímero

(f)

Figura 6.54: Observações da coloração Gram nas morfologias, obtidas por microscopia de contraste de fase, referentes æ̀ amostras do reator ao final da operação com $495 \mathrm{mg} / \mathrm{L}$ de glicose e 3 horas de ciclo: (a) bacilos com dimensões variadas de coloração Gram (-), bacilos com extremidades arredondas Gram (+) e filamento de bacilos Gram (-), (b) morfologias semelhantes as fototróficas anoxigênicas Gram (-) e estruturas semelhantes a bacilos retos com inclusão Gram (+); (c) hifa de fungos; (d) bacilos com dimensões variadas de coloração Gram (-), bacilos com extremidades arredondas Gram (+), (e) bacilos de dimensões variadas e filamentos delgadas Gram (-); (f) bacilos Gram (-) agrupados. 


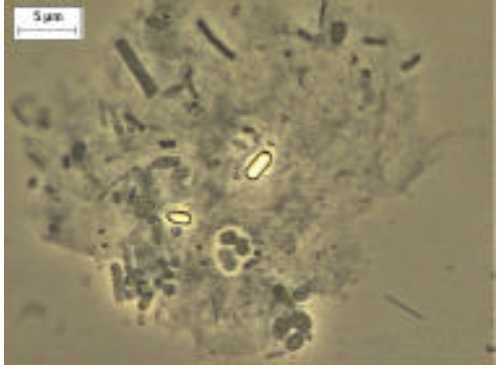

(a)

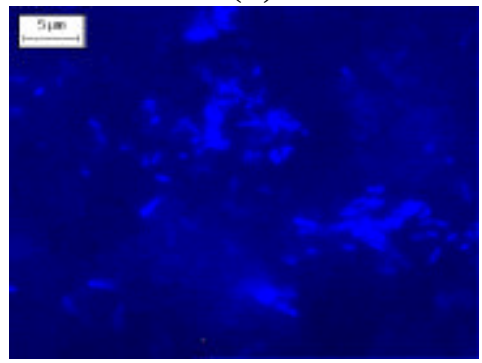

(d)

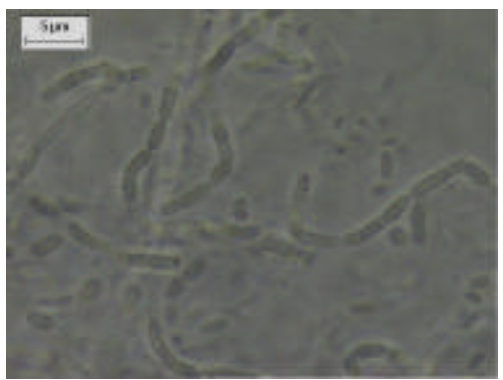

(g)

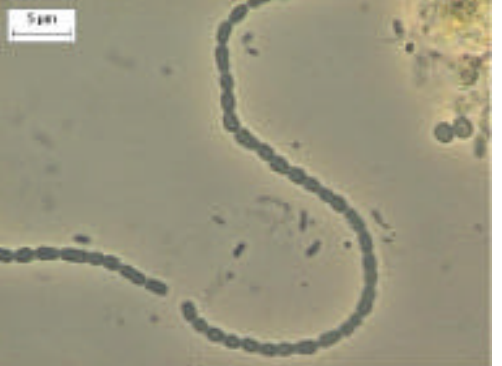

(b)

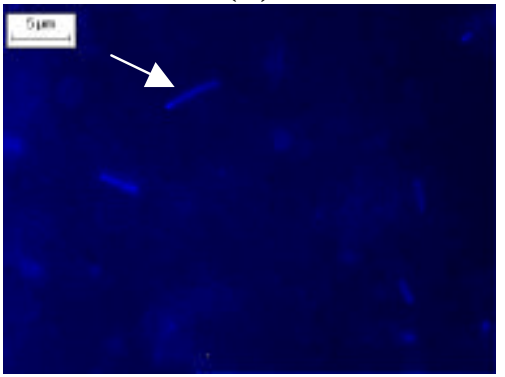

(e)

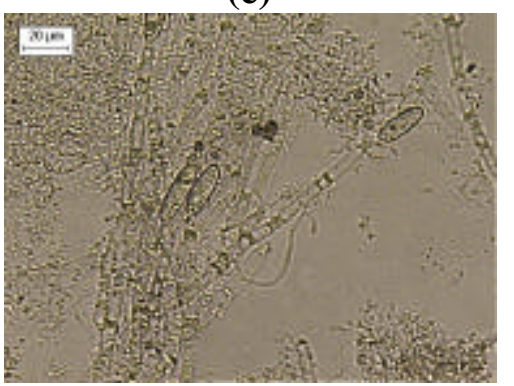

(h)

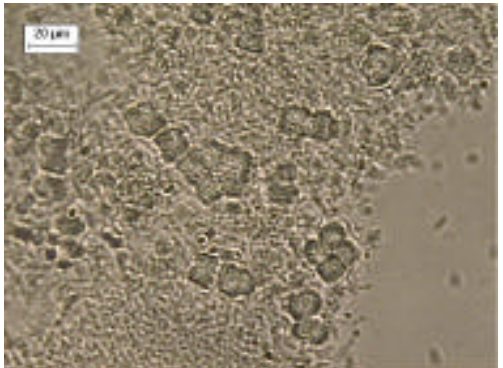

(c)

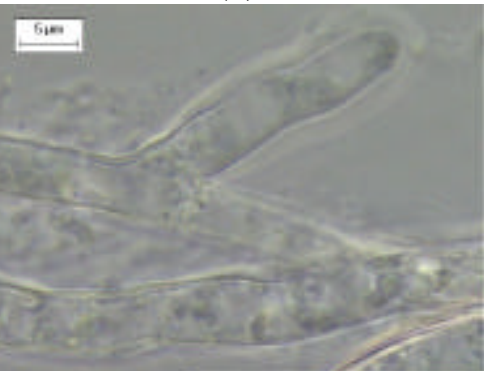

(f)

Figura 6. 55: Observações morfológicas sob microscopia de contraste de fase e epifluorescência, referentes à amostras do reator ao final da operação com $990 \mathrm{mg} / \mathrm{L}$ de glicose e 3 horas de ciclo: (a) estruturas semelhantes a endosporos e bacilos de dimensões variadas; (b) filamento de bacilos; (c) estruturas semelhantes a Methanosarcianas; (d) bacilos fluorescentes com morfologia semelhante a Arquea methanogênca hidrogenotrófica; (e) bacilo fluorescente semelhante a Arquea methanospirillum; (f) hifas de fungos; (g) filamentos de bacilos; (h) hifas e esporos de fungos. 

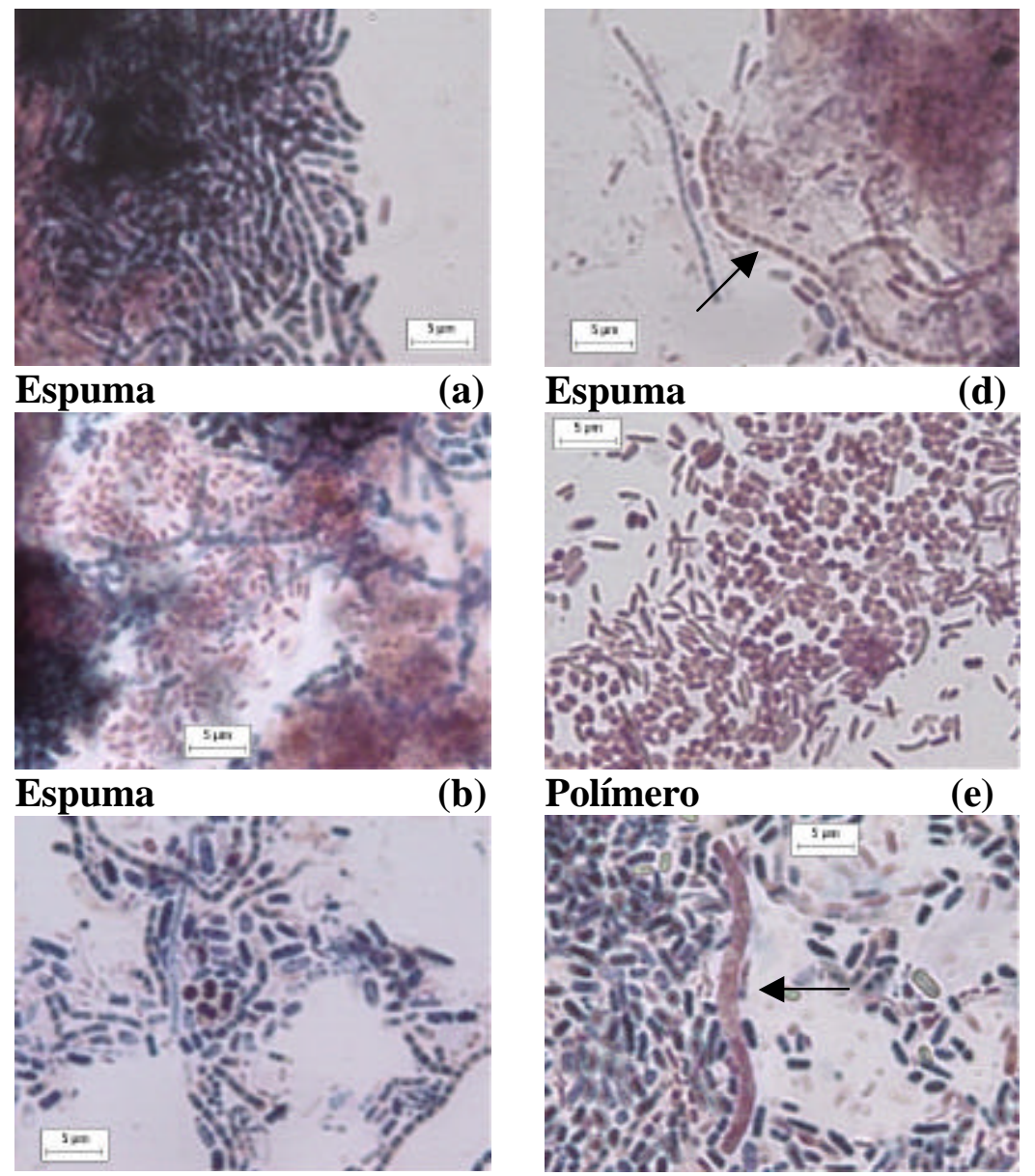

Espuma

(c)

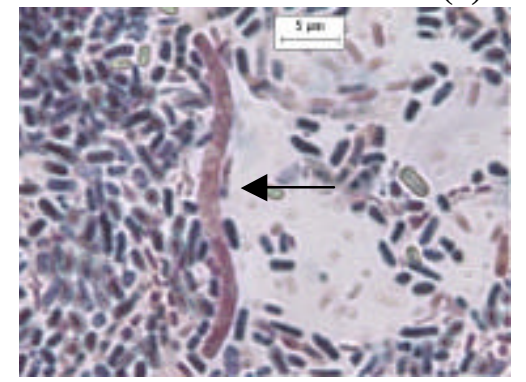

Polímero

(f)

Figura 6.56: Observações da coloração Gram nas morfologias, obtidas por microscopia de contraste de fase, referentes à amostras do reator ao final da operação com 990 mg/L de glicose e 3 horas de ciclo; (a) filamentos de bacilos Gram (+); (b) bacilos Gram (-); (c) bacilos Gram (+); (d) filamento septado Gram (-); (e) cocos e bacilos Gram (+); (f) estrutura semelhante ao bacilo curvo com inclusão apresentando coloração Gram (-). 


\section{CONCLUSÕES}

Os resultados obtidos com o ASBBR operando com ciclo de 8 horas permitiram as seguintes conclusões:

- A operação do ASBBR com concentração de glicose de $470 \pm 37$ mg/L e 65 ciclos foi estável atingindo alta eficiência na remoção da matéria orgânica (média de 95\%).

- A operação do sistema com $852 \pm 190 \mathrm{mg} / \mathrm{L}$ de glicose, durante 147 ciclos, também apresentou boa remoção da matéria orgânica (média de 84\%). A alcalinidade a bicarbonato indicou o equilíbrio na conversão da matéria orgânica. No entanto, as concentrações dos ácidos voláteis no efluente (159 \pm 72 $\mathrm{mg} / \mathrm{L}$ ) indicaram alguma possível instabilidade operacional do sistema.

- Operando-se com $1943 \pm 205 \mathrm{mg} / \mathrm{L}$ de glicose, também foi observada boa remoção da matéria orgânica (média de $74 \%$ ), não sendo observada presença de glicose no efluente como nas condições anteriores. Porém o reator mostrou-se instável com consumo da alcalinidade a bicarbonato e concentrações de ácidos voláteis no efluente de $374 \pm 92$.

- A instabilidade operacional, observada a partir da operação com $852 \pm 190 \mathrm{mg} / \mathrm{L}$ e agravada quando se operou com $1943 \pm 205 \mathrm{mg} / \mathrm{L}$ de glicose, foi devida, principalmente, à formação de material viscoso, similar a polímeros extracelulares (EPS), que ficou aderido no cesto, na parede do reator e nos interstícios do leito de espuma.

- A acúmulo de EPS pode ter causado problemas hidrodinâmicos e limitação à transferência de massa do meio líquido para as biopartículas, sendo responsável pela crescente instabilidade observada na medida em que se aumentou a concentração de substrato no afluente.

- A degradação total da glicose ocorreu em 90 minutos de reação independente da concentração inicial.

- O modelo cinético de primeira ordem representou bem o consumo da glicose e o 
- modelo de primeira ordem modificado, considerando concentração residual de substrato, representou bem degradação da matéria orgânica total, medida como DQO.

- A degradação da matéria orgânica total, medida como DQO, ocorreu em duas fases distintas, ambas representadas pelo modelo de primeira ordem modificado. Os valores dos parâmetros cinéticos indicaram que a primeira fase representou a degradação da glicose e a segunda, a degradação dos compostos intermediários. Portanto, os produtos intermediários só foram consumidos após o total consumo da glicose.

- Embora não tenha havido diferenças entre as constantes cinéticas para degradação de glicose nos dois perfis realizados, a constante cinética de degradação dos produtos intermediários foi bem menor no segundo caso, indicando que o acúmulo de EPS interferiu principalmente na degradação dos compostos intermediários, provavelmente, dificultando a transferência dos mesmos do meio líquido para as células do biofilme.

Os resultados obtidos com o ASBBR operando com ciclo de 3 horas permitiram as seguintes conclusões:

- A produção de EPS não está relacionada, nesse caso, com o longo período que a biomassa foi submetida a baixas concentrações quando o reator foi operado com ciclo de 8 horas. Esta conclusão se baseia nos resultados obtidos com a operação com ciclo de 3 horas, durante a qual foi observada maior produção de EPS quando comparada com a condição anterior.

- A produção de EPS, reconhecida como sendo a principal causa de desestabilização do sistema, pode estar relacionada com a exposição da biomassa a concentrações relativamente altas de ácidos graxos voláteis, ao aumento progressivo da carga orgânica ou mesmo a uma característica intrínseca dos organismos anaeróbios imobilizados e alimentados com glicose.

- Não se observou a presença de glicose no efluente, nas duas condições de operação, com $495 \pm 35$ mg/L e $990 \pm 72$ mg/L.

- Observou-se maior acúmulo de ácidos voláteis nas duas condições, quando se comparou com 180 minutos de reação nos ciclos de 8 horas.

- A maior freqüência de enchimento e esvaziamento do reator, nessa fase operacional, pode ter sido responsável pelo aumento do potencial de óxidoredução em relação ao observado na operação com ciclo de 8 horas. No entanto, 
isso parece não ter interferido no desempenho geral do processo. Este fato, entretanto, não pode ser confirmado através das observações microbiológicas, nas quais não foi verificado a frequiência de microrganismos que crescem em condições de microaerofilia, tais como protozoários, sendo comum a presença de fototróficas anoxigênicas nas espumas.

- Nesse caso também, o modelo cinético de primeira ordem representou bem o consumo da glicose e o modelo de primeira ordem modificado, considerando concentração residual de substrato, representou bem degradação da matéria orgânica total, medida como DQO. 


\section{SUGESTÕES}

Sugestões para trabalhos futuros:

- Realizar estudos mais aprofundados para verificar o principal motivo da formação de EPS.

- Verificar a composição do EPS.

- Avaliar o desempenho do reator tratando água residuária de fácil degradação com tempos de ciclos maiores que 8 horas.

- Desenvolver modelo matemático para o ASBBR no tratamento de compostos de fácil degradação para estimar carga orgânica suportável e o tempo de reação necessário 


\section{REFERÊNCIAS BIBLIOGRÁFICAS}

ALLISON, D. G. AND SUTHERLAND, I.W. (1987). The Role of Exoolysaccharides in Adhesion of Freshwater Bacteria. J. Gen. Micro. 133: 1319-1327.

AlVES, M.M., PEREIRA, M.A., NOVAIS, J.M., POLANCO, F.F., MOTA, M. (1999). A New Device to Select Microcarriers for Biomass Immobilization: Application to an Anaerobic Consortium. Wat. Environ. Res.:71 (2): 209-217.

ANGENENT, L.T., DAGUE, R.R. (1995). A Laboratory-Scale Comparison of the UASB and ASBR Processes. In: 50th Purdue Ind. Waste Conference Proceedings, Ann Arbor Press, Chelsea, Michigan, p. 365-377.

BAGLEY, M., BRODKORB, T.S. (1999). Modeling Microbial Kinetics in an Anaerobic Sequencing Batch Reactor - Model Development and Experimental Validation. Wat. Environ. Res. 71: 1320-1332.

BONET, R., SIMONPUJOL, M.D., CONGREGADO, F. (1993). Effects of Nutrients on Exopolysaccharide Production and Surface Properties of Aeromonas salmonicida. Appl. And Env. Micr. 59 (8): 2437-2441.

BRITO, A.G., RODRIGUES, A.C., MELO, F.L. (1997). Feasibility of a Pulsed Sequencing Batch Reactor with Anaerobic Aggregated Biomass for the Treatment of Low Strength Wastewaters. Wat. Sci. Technol. 35: 193-198.

CALZADA, J.F., ARRIOLA, M.C., CASTAÑEDA, H.O., GODOY, J.E., ROLZ, C. 
(1984). Methane from Coffee Pulp Juice: Experiments Using Polyurethane Foam Reactors. Biotechnol. Letters, 6 (6): 385-388.

CHANG, D., HUR, J.M., CHUNG, T.H. (1994). Digestion of Municipal Sludge by Anaerobic Sequencing Batch Reactor. Water Sci. Technol. 30, 12, 161.

CHRYSI, S.L., BRUCE, E.R. (2002). A Unified Theory for Extracellular Polymeric Substances, Soluble Microbial Products, and Active and Inert Biomass. Wat. Res. 36:2711-2720.

CUBAS, S.A., FORESTI, E., RODRIGUES, J.A.D., RATUSZNEI, S.M., ZAIAT, M. (2001). Influence of the Liquid-phase Mass Transfer on the Performance of a stirred anaerobic sequencing batch reactor containing immobilized biomass. Aceito para apresentação oral no 9th World Congress Anaerobic Digestion 2001, Antuérpia, Bélgica.

CUBAS, S.A., PINHO, S.C., FORESTI, E., RODRIGUES, J.A.D., RATUSZNEI, S.M., ZAIAT, M. (2002) Effects of Solid-phase Mass Transfer on a Stirred Anaerobic Sequencing Batch Reactor Containing Immobilized Biomass. VII Taller y Simposio Latinoamericano Sobre Digestión Anaerobia, Mérida, Yucatán, México, 229-236.

DAGUE, R.R., HABBEN, C.E., PIDAPARTI, S.R. (1992). Initial Studies on the Anaerobic Sequencing Batch Reactor. Wat. Sci. Technol. 26: 2429-2432.

DAGUE, R.R., BANIK, G.C., ELLIS, T. G. (1998). Anaerobic Sequencing Batch Reactor Treatment of Dilute Wastewater at Pschrophilic Temperatures. Water Envirom. Res., 70: 155-160.

DEL NERY, V. (1987). Utilização de Lodo Anaeróbio Imobilizado em Gel no Estudo de Partida de Reatores de Fluxo Ascendente com Manta de Lodo. São Carlos.SP. Dissertação (Mestrado) Escola de Engenharia de São Carlos, USP. 
DILALlO, R., ALBERTSON, O.E. (1961). Volatile Acids by Direct Titration. Journal WPCF, v. 33, n. 4, p. 356-365.

DROSTE, R.L., MASSÉ, D.I. (1995). Anaerobic Treatment in Sequencing Batch Reactors. Int. Symp. on Technol. Transfer, Salvador - BA, Brasil, pp. 353-363.

FERNANDES, L., KENNEDY, K.J., NING, Z. (1993). Dynamic Modeling of Substrate Degradation in Sequencing Batch Anaerobic Reactors (SBAR). Wat. Res. 27: 1619-1628.

FYNN, G.H., WHITMORE, T.N. (1984). Retention of Methanogens in Colonised Reticulated Polyurethane Foam Biomass Support Particle. Biotechnol. Letters, 6 (2); 81-86.

GIJZEN, H.J., SCHOENMAKERS, T.J.M., CAERTELING, C.G.M., VOGELS, G.D. (1988). Anaerobic Degradation of Papermill Sludge in a Two-Phase Digester Containing Rumen Microorganisms and Colonized Polyurethane Foam.Biotechnol. Letters, 10 (1): 61-66.

HARPER, S.R., POHLAND, F.G. (1985). Recent Developments in Hydrogen Management During Anaerobic Biological Wastewater Treatment. Biotechonol. And Bioengineering, XXVIII: 585-602.

HOLlOPETER, J.A., DAGUE, R.R. (1994). Anaerobic Sequencing Batch Reactor Treatment of Landfill Leachate. In. Purdue Ind. Waste Conference Proceedings, 49. Anais Chelesa, Ann Arbor Press.

HUYSMAN, P., MEENEN, P.V., ASSCHE, P.V., VERSTRAETE, W. (1993). Factors Affecting the Colonization of Non Porous and Porous Packing Materials in Model Upflow Methane Reactors. Biotechnol. Letters, 5 (9):643-648.

KÖRSTGENS, V., FLEMMING, H.C., WINGENDER, J., BORCHARD, W. (2001).Influence of Calcium Ions on the Mechanical Properties of a Model 
Biofilm of Mucoid Pseudomonas aeruginos. W. Science \& Technology 43:4959.

LARPIN, S., SAUVAGEOT, N., PICHEREAU, V., LAPLACE, J.M., AUFFRAY, Y. (2002). Biosynthesis of Exopolysaccharide by a Bacillus licheniformis Strin Isolated from Ropy Cider. Int. J. Food Microbiol. 77: 1-9.

MAGARITIS, A. AND PACE, G.W. (1985).Microbial Polysaccharides. Comprehensive Biotechnology. The Principles, Applications and Regulations of Biotechnology in Industry, Agriculture and Medicine. Ed.Pergamn Press, vol. 3.

MILLER, J.C., MILLER, J.N. (1984). Statistics for Analytical Chemistry, Ellis Horwood, Chischester. p. 96, cap. 4.

MORAES, E. M., ADORNO, M. A. T., ZAIAT, M., FORESTI E. (2000). Determinação de Ácidos Voláteis Totais por Cromatografia Gasosa em Efluentes de Reatores Anaeróbios Tratando Resíduos Líquidos e Sólidos. In: Oficina e Seminário Latino-Americano de Digestão Anaeróbia, 6, Recife-PE. Anais. Editora Universitária da UFPE, Recife. 2: 235-238.

MOZZI, F., ROLLAN, G., DE GIORI, G.S., DE VALDEZ, G.F. (2001) Effect of Galactose and Glucose on the Exopolysaccharide Production and the Activities of Biosynthetic Enzymes in Lactobacillus casei CRL 87. J. Ap. Microbil. 91 (1): 160-167.

NDON, U.J., DAGUE, R.R.(1997). Effects of Temperature and Hydraulic Retention Time on Anaerobic Sequencing Batch Reactor Treatment of Low-Strength Wastewater. Water Res. 10,2455.

PETRY, S., FURLAN, S., CREPEAU, M.J., CERNING, J., DESMAZEAUD, M. (2000). Factors Affecting Exocellular Polysaccharide Production by Lactobacillus delbrueckii subsp. bulgaricus Grown in a Chemically Defined Medium. Ap. Envir. Microbiol. 66: 3427-3431. 
PINHO, S.C., CUBAS, S.A., RATUSZNEI, S.M., RODRIGUES, J.A.D., FORESTI, E., ZAIAT, M (2002) Influence of the Agitation Rate on the Treatment of Partially Soluble Wastewater in Anaerobic Sequencing Batch Reactor Containing Immobilized Biomass. VII Taller y Simposio Latinoamericano Sobre Digestión Anaerobia, Mérida, Yucatán, México, 103-106

QUAGLIANO, J.C. AND MIYAZAKI, S.S. (1999) Biosynthesis of Poly-betahydroxybutyrate and Exopolysaccharides on Azotobacter chroococcum Strain 6B Utilizing Simple and Complex Carbon Sources. Ap. Biochem. And Biotechnology 82 (3): 199-208.

RATUSZNEI, S.M., RODRIGUES, J.A.D., CAMARGO, E.F.M., ZAIAT, M., BORZANI, W. (2000). Feasibility of a Stirred Anaerobic Sequencing Batch Reactor Containing Immobilized Biomass for Wastewater Treatment. Bioresource Technol., 75:127-132.

RATUSZNEI, S.M., RODRIGUES, J.A.D., CAMARGO, E.F.M., RIBEIRO, R., ZAIAT, m. (submitted). Feeding Strategy Effects on the Operating Behavior of a Stirred Anaerobic Sequencing Fed-batch Reactor Containing Immobilized Biomass Treating Low-strength Wastewater. Bioresource Technology

RIBEIRO, R. (2001). Influência do Tipo de Substrato na Dinâmica de Formação do Biofilme em Matrizes de Espuma de Poliuretano. Dissertação (Mestrado) Escola de Engenharia de São Carlos, Universidade de São Paulo.

RIPLEY, L.E., BOYLE, W.C., CONVERSE, J.C. (1986) Improved Alkalimetric Monitoring for Anaerobic Digestion of High-strength Wastes. J.WPCF, 58: 406 $-411$.

SANCHEZ, J.M., ARIJO, S., MUÑOZ, M.A., MORIÑIGO, M.A., BORREGO, J.J. (1994). Microbial Colonization of Different Support Materials Used to Enhance the Methanogenic Process. Applied Microbiology and Biotechnology, v.41, 
p.480-486

SCHMIT, C.G.,DAGUE, R.R. (1993) Anaerobic Sequencing Batch Reactor Treatment of Swine Wastes at $20^{\circ} \mathrm{C}, 25^{\circ} \mathrm{C}$, and $35^{\circ} \mathrm{C}$. $48 \mathrm{IN}$ Purdue Industrial Waste Conference Proceedings, p.541-549.

SHIZAS, I., BAGLEY, D.M. (2001). Improving Anaerobic Sequencing Batch Reactor Performance by Modifying Operational Parameters. Wat. Res., 36: 363367.

SPEECE, R.E. (1996). Anaerobic Biotechnology for Industrial Wastewaters. Neshville, Archae Press.

STANDARD METHODS FOR EXAMINATION OF WATER AND WASTEWATER (1998). APHA, AWAA, and WPCF. Washington D. C., American Publications Health Association. $20^{t^{\mathrm{a}}}$ edição.

SUNG, S., DAGUE, R.R. (1995). Laboratory Studies on the Anaerobic Sequencing Batch Reactor. Wat. Environ. Res. 67: 294-301.

SUTHAKER, S., POLPRASERT, C, DROSTE, R.L., (1991). Sequencing Batch Anaerobic Reactors for Treatment of a High-strength Organic Waste-water. WATER SCI TECHNOL 23 (7-9): 1249-1257

SUTHERLAND, I.W. (2001). Exopolysaccharides in Biofilms, Flocs and Related Structures. W. Science \& Tech. 43: 77-87.

TAKEI, A., SHOGA, Y., HAMA, M., HONDA, Y., SUGIMURA, Y., OTSUJI, K. (1995) Production of Polysaccharides by Liquid Cultures of Polianthes tuberosa Cells - High Production by Reduction in the Viscosity of Culture-Medium. Biotechnology Tec. 9: 253-258. 
TIMUR, H., ÖSTURK, I. (1999). Anaerobic Sequencing Batch Reactor Treatment of Landfill Leachate. Wat. Res., 33: 3225-3230.

VARESCHE, M.B., ZAIAT, M., VIEIRA L.G.T., VAZOLLER, R.F., FORESTI, E. (1997). Microbial Colonization of Polyurethane Foam Matrices in HorizontalFlow Anaerobic Immoblized-Sludge Reactor. Appl. Microbiol. Biotechnol , 48: 534-538.

VEIGA, M.C., JAIN, M.K., WU, W.M., HOLLINGSWORTH, R.I., ZEIKUS, J.G. (1996) Composition and Role of Extracellular Polymers in Methanogenic Granules. Ap. Env. Microbiol. 63: 403-407.

VIEIRA, L.G.T. (1996). Estimativa de Parâmetros Cinéticos Intrínsecos de Utilização de Substrato por Lodo Anaeróbio Imobilizado. Dissertação (Mestrado) - Escola de Engenharia de São Carlos - USP, São Carlos, SP.

ZAIAT, M., CABRAL, A.K.A. AND FORESTI, E. (1994). Horizontal-Flow Anaerobic Imobilized Sludge Reactor for Wastewater Treatment: Conception and Performance Evaluation (in Portuguese). Revista Brasileira de Engenharia Caderno de Engenharia Química, 11: 33 - 42.

ZAIAT, M., CABRAL, A.K.A, FORESTI, E. (1996). Desenvolvimento de Reator Anaeróbio Horizontal de Leito Fixo (RAHLF) para Tratamento de Águas Residuárias. Tese (Doutorado). Escola de Engenharia de São Carlos, USP.

ZAIAT, M., CABRAL, A.K.A, FORESTI, E. (1996). Cell Wash-Out and External Mass Transfer Resistance in Horizontal-Flow Anaerobic Immobilized Sludge Reactor. Wat. Res., 30 (10): 2435-2439.

ZAIAT, M., RODRIGUES, J.A.D., RATUSZNEI, S.M., CAMARGO, F.M., BORZANI, W.. (2001). Anaerobic Sequencing Batch Reactors for Wastewater Treatment: Developing Technology. Appl. Microbiol Biotechnol, 55:29-35. 
ZHANG, R., YIN,Y., SUNG, S., DAGUE, R.R. (1997). Anaerobic Treatment of Swine Waste by the Anaerobic Sequencing Batch Reactor. 51 ${ }^{\mathrm{IN}}$ Purdue Industrial Waste Conference Proceedings, p.315-321.

WRANGSTADH, M., CONWAY, P.L., KJELlEBERG, S. (1989) The Role of an Extracellular Polysaccharide Produced by Washed Suspensions. J. Gen. Microbiol. 116: 133-141. 
